\title{
Technical Status Report on Immiscibility Prediction and Effects in HLW
}

by

R. L. Schulz

Westinghouse Savannah River Company

Savannah River Site

Aiken, South Carolina 29808

C. M. Jantzen

DOE Contract No. DE-AC09-96SR18500

This paper was prepared in connection with work done under the above contract number with the U. S. Department of Energy. By acceptance of this paper, the publisher and/or recipient acknowledges the U. S. Government's right to retain a nonexclusive, royalty-free license in and to any copyright covering this paper, along with the right to reproduce and to authorize others to reproduce all or part of the copyrighted paper. 
WSRC-TR-2000-00010

Keywords: waste glass, phase separation, glass durability, glass quality

\section{TECHNICAL STATUS REPORT ON IMMISCIBILITY PREDICTION AND EFFECTS IN HLW GLASSES (U)}

R.L. Schulz and C.M. Jantzen

Westinghouse Savannah River Technology Center

Aiken, SC 29808

Prepared for

Tank Waste Focus Area

TTP\# AE1-6-WT-31

Subtask A

Milestone A.2-6

Approved by

E.W. Holtzscheiter, Manager

Immobilization Technology Section

Publication Date: January 15, 2000

Westinghouse Savannah River Co.

Savannah River Site

Aiken, SC 29808

PREPARED FOR THE DEPARTMENT OF ENERGY UNDER CONTRACT

DE-AC09-96SR18500

Westinghouse Savannah River Company

Savannah River Site

Aiken, SC 29808

PREPARED FOR THE U.S. DEPARTMENT OF ENERGY UNDER CONTRACT NO. DE-AC09-96SR18500

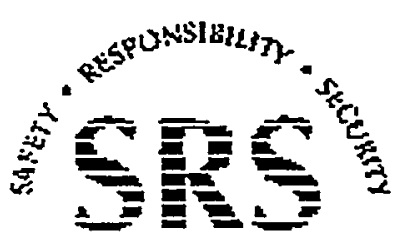

S.Y VANNAH RIVER SITE 


\section{DISCLAIMER}

This report was prepared as an account of work sponsored by an agency of the United States Government. Neither the United States Government nor any agency thereof, nor any of their employees, makes any warranty, express or implied, or assumes any legal liability or responsibility for the accuracy, completeness, or usefulness of any information, apparatus, product or process disclosed, or represents that its use would not infringe privately owned rights. Reference herein to any specific commercial product, process or service by trade name, trademark, manufacturer, or otherwise does not necessarily constitute or imply its endorsement, recommendation, or favoring by the United States Government or any agency thereof. The views and opinions of authors expressed herein do not necessarily state or reflect those of the United States Government or any agency thereof.

This report has been reproduced directly from the best available copy.

Available for sale to the public, in paper, from: U.S. Department of Commerce, National Technical Information Service, 5285 Port Royal Road, Springfield, VA 22161, phone: (800) 553-6847

fax: (703) 605-6900

email: orders@ntis.fedworld.gov

online ordering: http://www.ntis.gov/ordering.htm

Available electronically at http://www.doe.gov/bridge

Available for a processing fee to U.S. Department of Energy and its contractors, in paper, from: U.S. Department of Energy, Office of Scientific and Technical Information, P.O. Box 62, Oak Ridge, TN 37831-0062, phone: (865) 576-8401

fax: (865) 576-5728

email: reports@adonis.osti.gov 


\section{DISCLAIMER}

Portions of this document may be illegible in electronic image products. Images are produced from the best available original document. 


\section{Approvals}

Pede

R.L. Schulz, Author

$\frac{\text { C.m.tantrem }}{\text { C.M. Jantzed, Authon }}$

TLC

A. D. Cozzi, Technical Reviewer

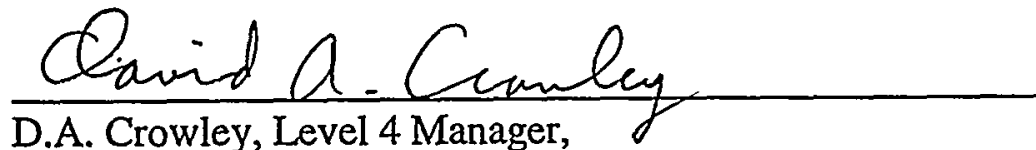

Immobilization Technology Section

Punes for

E. W. Hollzscheiter, Level 3 Manager,

Immobilization Technology Section $\angle 1300$

Date

$1-1300$

Date

$\frac{1 / 13 / 00}{\text { Date }}$

$1 / 13 / 00$

Date

$1-13-00$

Date 


\section{EXECUTIVE SUMMARY}

As part of the Tanks Focus Area's (TFA) effort to increase waste loading for high-level waste vitrification at various facilities in the Department of Energy (DOE) complex, the occurrence of phase separation in waste glasses spanning the Savannah River Site (SRS) and Idaho National Engineering and Environmental Laboratory (INEEL) composition ranges were studied. The type, extent, and impact of phase separation on glass durability for a series of SRStype and INEEL-type glasses were examined.

Phase separation has been shown to have an adverse and unpredictable effect on the durability of borosilicate nuclear waste glasses containing little to no phosphate in the United States and in Europe. For this reason, glass compositions that have a tendency to phase separate are excluded from consideration during waste processing at SRS via a compositionally dependent phase separation model. The formation of liquid-liquid phase separation in molten glass at high temperatures is kinetically a very rapid phenomenon. The effects of glass chemistry and thermal history (slow cooling) of the waste glass during solidification in a waste canister can impact the kinetics of phase separation and thus, the long term durability of a glass. A series of experiments spanning a liquid-liquid immiscibility boundary in composition space were undertaken varying the cooling kinetics (thermal history) expected in a waste glass canister at the surface and at the centerline. This was accomplished by adding excess frit (known to be phase separated) to waste glasses (known to be homogeneous).

The scale of the phase separation observed in the waste glass/frit mixtures appears to have been macroscopic as the glasses separated into a less dense (top) and a more dense (bottom) phase which could be observed with the naked eye. When rapidly quenched into a pan, the glasses were found to be a mechanical mixture of the two separated phases. This demonstrates that the phase separation occurs at or near the melt temperature, e.g. stable immiscibility. For all the waste glass/frit mixtures cooled via the centerline cooling regime, the denser phase contained more crystals of spinel and acmite than the less dense phase. Crystals were not observed in the samples cooled via the surface cooling regime. The results of the kinetics work demonstrated that there were larger compositional differences between the separated phases in the more rapid canister surface cooled samples than in the canister centerline cooled samples. This is consistent with the 1999 findings of Tomozawa that a rapidly cooled specimen can have a phase-separated structure that can disappear upon low-temperature annealing. This also implies that the DWPF phase separation model is conservative in that it avoids glass compositions that have a tendency to phase separate at the melt temperature which have the potential to be annealed or rehomogenized as the waste glass canisters cool. The model does not address glasses that are not phase separated at the melt temperature but phase separate upon cooling through a metastable immiscibility region.

The effects of the phase separation and composition on glass durability were examined for two waste glass/frit mixtures that were shown to exhibit macroscopic phase separation. The glass durability is complicated by the crystallization occurring in the centerline cooled glasses. Crystals were not observed in the simulated surface cooled glasses, but macroscopic phase separation was. In the $80 \%$ waste glass $/ 20 \%$ excess frit centerline cooled glass, the separated phases had a poorer durability than the corresponding glasses surface cooled. In the surface cooled glass, the less dense phase was somewhat less durable than the denser phase. At $20 \mathrm{wt} \%$ excess frit the durability of all of the phases (dense and less dense) was still considerably lower than the durability of the Environmental Assessment (EA) glass. However, for both the 
centerline and surface cooled glasses at the $80 \mathrm{wt} \%$ excess frit level, durability fell into the unacceptable range.

Phase separation of phosphate rich phases in borosilicate waste glasses is less well studied than phase separation in borosilicate glasses with little or no phosphate. One option for immobilization of high level waste at the INEEL is to dissolve calcined waste and then separate the High Activity Waste (HAW) portion for vitrification. The separation process concentrates the radionuclides in the HAW but also adds large concentrations of $\mathrm{P}_{2} \mathrm{O}_{5}$ to the HAW. Concentrations of $\mathrm{P}_{2} \mathrm{O}_{5}$ in excess of 2.5-3 wt\% are known to cause phase separation in borosilicate waste glasses. The phase separated phosphate rich regions are droplet like and rapidly transform into crystalline alkali phosphate phases. The formation of these crystalline phases shows that some glass compositions containing up to $\sim 19$ wt\% $\mathrm{P}_{2} \mathrm{O}_{5}$ are durable even thought they have undergone phase separation/crystallization. Mathematical analysis of glass durability data showed that high $\mathrm{Al}_{2} \mathrm{O}_{3}$ stabilized the glass matrix and made the glasses durable. The high $\mathrm{Al}_{2} \mathrm{O}_{3}$ content did not stabilize the glass against phase separation as it does in nonphosphate containing borosilicate glass systems. 
WSRC-TR-2000-00010, Revision 0

TABLE OF CONTENTS

1.0 INTRODUCTION......................................................................

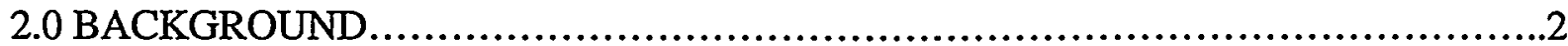

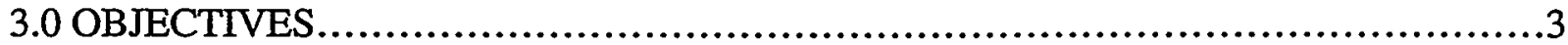

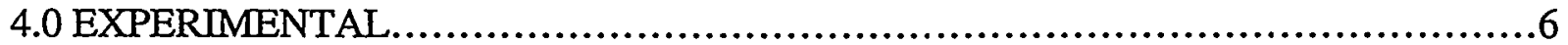

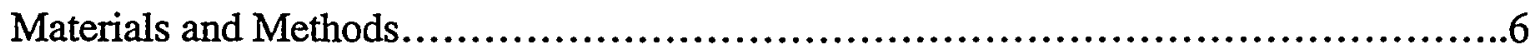

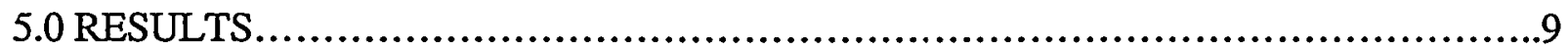

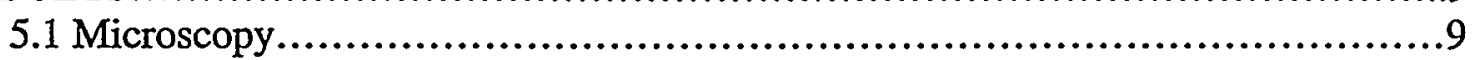

5.2 Compositional Analyses and Density Measurements...........................34

5.3 Product Consistency Test - PCT.............................................34

5.4 INEEL Phase Separations...................................................48

6.0 CONCLUSIONS.....................................................................53

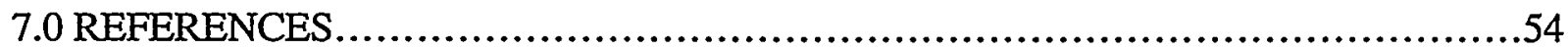


WSRC-TR-2000-00010, Revision 0

\title{
TECHNICAL STATUS REPORT ON IMMISCIBILITY PREDICTION AND EFFECTS IN HLW GLASSES (U)
}

\author{
R.L. SCHULZ AND C.M. JANTZEN \\ Westinghouse Savannah River Technology Center \\ Savannah River Site \\ Aiken, South Carolina 29808
}

\subsection{INTRODUCTION}

As part of the Tanks Focus Area's (TFA) effort to increase waste loading for high-level waste vitrification at various facilities in the Department of Energy (DOE) complex, the occurrence of phase separation in waste glasses spanning the Savannah River Site (SRS) and Idaho National Engineering and Environmental Laboratory (INEEL) composition ranges were studied. The type, extent, and impact of phase separation on glass durability for a series of SRS-type and INEEL-type glasses were examined.

Phase separation has been shown to have an adverse and unpredictable effect on durability of borosilicate nuclear waste glasses containing little to no phosphate in the United States ${ }^{1,2,3}$ and in Europe.

${ }^{4}$ For this reason, in the SRS Defense Waste Processing Facility (DWPF) glass compositions that have a tendency to phase separate are excluded from consideration during waste processing. ${ }^{2,5}$ The formation of liquid-liquid phase separation in molten glass at high temperatures is kinetically a very rapid phenomena. The effects of glass chemistry and thermal history (slow cooling) of the waste glass during solidification in a waste canister can impact the kinetics of phase separation and thus, the long term durability of a glass. A series of experiments spanning a liquid-liquid immiscibility boundary in composition space were undertaken for various DWPF glasses spanning the composition range to be processed in the DWPF, e.g. glasses. from the DWPF Waste Compliance Plan (WCP) spanning compositions rich in $\mathrm{Al}_{2} \mathrm{O}_{3}$ ( $\mathrm{HM}$ wastes) to those rich in $\mathrm{Fe}_{2} \mathrm{O}_{3}$ (Purex wastes). The cooling kinetics (thermal history) expected in a waste glass canister was varied to simulated both the surface and the centerline cooling of a full-scale canister. The scale of the amorphous phase separation observed (microscopic vs. macroscopic vs. both), the kinetics, and the effects of the phase separation and composition on glass durability were examined. Once these effects are better understood, phase separation in Hanford HLW waste glasses can be examined.

The type and scale of phase separation in phosphate containing borosilicate glasses, such as those proposed for the processing of high level waste at the INEEL is different than the phase separation in borosilicate glasses containing less than 2.5-3 wt\% $\mathrm{P}_{2} \mathrm{O}_{5}$. The high concentrations of $\mathrm{P}_{2} \mathrm{O}_{5}$ in the INEEL wastes arise from one of the processing options: dissolution of calcined waste and then a separation of the High Activity Waste (HAW) portion for vitrification. It is the separation process that concentrates the radionuclides in the HAW and adds large concentrations of $\mathrm{P}_{2} \mathrm{O}_{5}$. In phosphate-rich glasses, phosphaterich regions form that are droplet like and rapidly transform into crystalline alkali phosphate phases, e.g. one phase the matrix remains amorphous while the other crystallizes. The scale of the phase separation observed, the kinetics, and the effects of the phase separation and composition on glass durability were examined. Once these effects are better understood, a recommendation can be made for a $\mathrm{P}_{2} \mathrm{O}_{5}$ process limit for INEEL waste glasses. 


\subsection{BACKGROUND}

Amorphous phase separation is typically defined as the separation, upon cooling, of a homogeneous melt into two or more liquid phases (e.g., glass-in-glass phase separation). Glasses that contain significant amounts of two or more glassformers are likely candidates for phase separation. Borosilicate glasses, although prone to amorphous phase separation, are widely used in the commercial glass industry. Compositions are selected to avoid the phase separated region or to take advantage of glass properties, such as thermal expansion, that are positively influenced by phase separation. When alkali borosilicate glasses undergo glass-in-glass phase separation, two compositions differing in composition usually develop that are not miscible in each other, e.g. like oil and water. Each compositional domain is usually enriched in one of the three major glass formers, silicon as $\left(\mathrm{SiO}_{4}\right)^{-4}$ tetrahedral units, boron as $\left(\mathrm{BO}_{4}\right)^{-5}$ tetrahedral units where $\mathrm{B}$ is IV coordinated or $\left(\mathrm{BO}_{3}\right)^{-3}$ trigonal units where $\mathrm{B}$ is III coordinated, or phosphate as $\left(\mathrm{PO}_{4}\right)^{-3}$ tetrahedral units. The competition for clominant structural role causes one or more of the three types of tetrahedral units to phase separate, e.g. in borosilicate glasses, $\left(\mathrm{PO}_{4}\right)^{-3}$ will separate first along with accompanying charge balancing cations. In general, the strong tendency toward phase separation can be anticipated from the competitive strong field strengths of the glass-formers $\mathrm{P}^{+5}=2.1$, $\mathrm{Si}^{4+}=1.57, \mathrm{~B}^{3+}=1.63_{\mathrm{III}}$ or $1.34_{\mathrm{IV}}$ (where $\mathrm{II}$ and $\mathrm{IV}$ refer to the number of oxygen ions surrounding each $\mathrm{B}$ ) which causes phase separation in all the known binary systems, e.g. $\mathrm{SiO}_{2}-\mathrm{B}_{2} \mathrm{O}_{3}, \mathrm{SiO}_{2}-\mathrm{P}_{2} \mathrm{O}_{5}$, and $\mathrm{B}_{2} \mathrm{O}_{3}-$ $\mathrm{P}_{2} \mathrm{O}_{5}{ }^{6}$ When all three cations are present, as in the $\mathrm{Na}_{2} \mathrm{O}-\mathrm{B}_{2} \mathrm{O}_{3}-\mathrm{SiO}_{2}-\mathrm{P}_{2} \mathrm{O}_{5}$ system, the cation with the highest field strength, $\mathrm{P}^{+5}$, dominates the de-mixing process, and gathers alkali from the already unmixed borosilicate phase into an additional droplet phase rich in $\mathrm{P}_{2} \mathrm{O}_{5}{ }^{6}$

In borosilicate glasses containing little or no phosphate (glasses predominately in the $\mathrm{Na}_{2} \mathrm{O}_{-}-\mathrm{B}_{2} \mathrm{O}_{3}-$ $\mathrm{SiO}_{2}$ system), a silica-rich phase often phase separates from an alkali-boron enriched domain. Tomozawa ${ }^{7}$ described the three types of phase separation based on microstructure:

Type A: Both phases are continuous and interconnected (see Figure 1A).

- the durability of the glass is governed by the least durable phase

- usually formed as a result of spinodal decomposition

Type B: A silica-rich phase is dispersed as droplets in a continuous matrix of an alkaliborate phase (see Figure 1B)

- the durability of the glass is governed by the continuous phase that is not durable

- usually formed by nucleation and growth.

Type C: An alkali-borate phase is dispersed as droplets in a continuous matrix of a silicarich phase (see Figure 1C)

- the durability of the glass is governed by the continuous phase that is highly durable

- usually formed by nucleation and growth.

Combinations of these microstructures commonly occur as shown in Figure 1B and 1C. Figure 1B shows "primary" phase separation of Type $\mathrm{B}$ (large $\mathrm{SiO}_{2}$-rich droplets in a sodium borate rich continuous matrix). However, the borate-rich continuous matrix has undergone a "secondary" phase separation of the Type $\mathrm{B}$ type and smaller $\mathrm{SiO}_{2}$-rich droplets can be seen within the borate-rich matrix. Likewise, in Figure 1C the "primary" phase separation is Type $\mathrm{C}$ and large sodium-borate rich droplets have formed in a durable $\mathrm{SiO}_{2}$-rich continuous matrix phase. There are also smaller Type $\mathrm{C}$ sodium-borate rich precipitates in the continuous $\mathrm{SiO}_{2}$-rich matrix formed by "secondary" phase separation. In addition, the large sodium-rich droplets have undergone a Type B "secondary" phase separation. The resulting glass has 4 different phases - three Type $C$ separated phases and one Type B separated phase. ${ }^{6}$ 
WSRC-TR-2000-00010, Revision 0

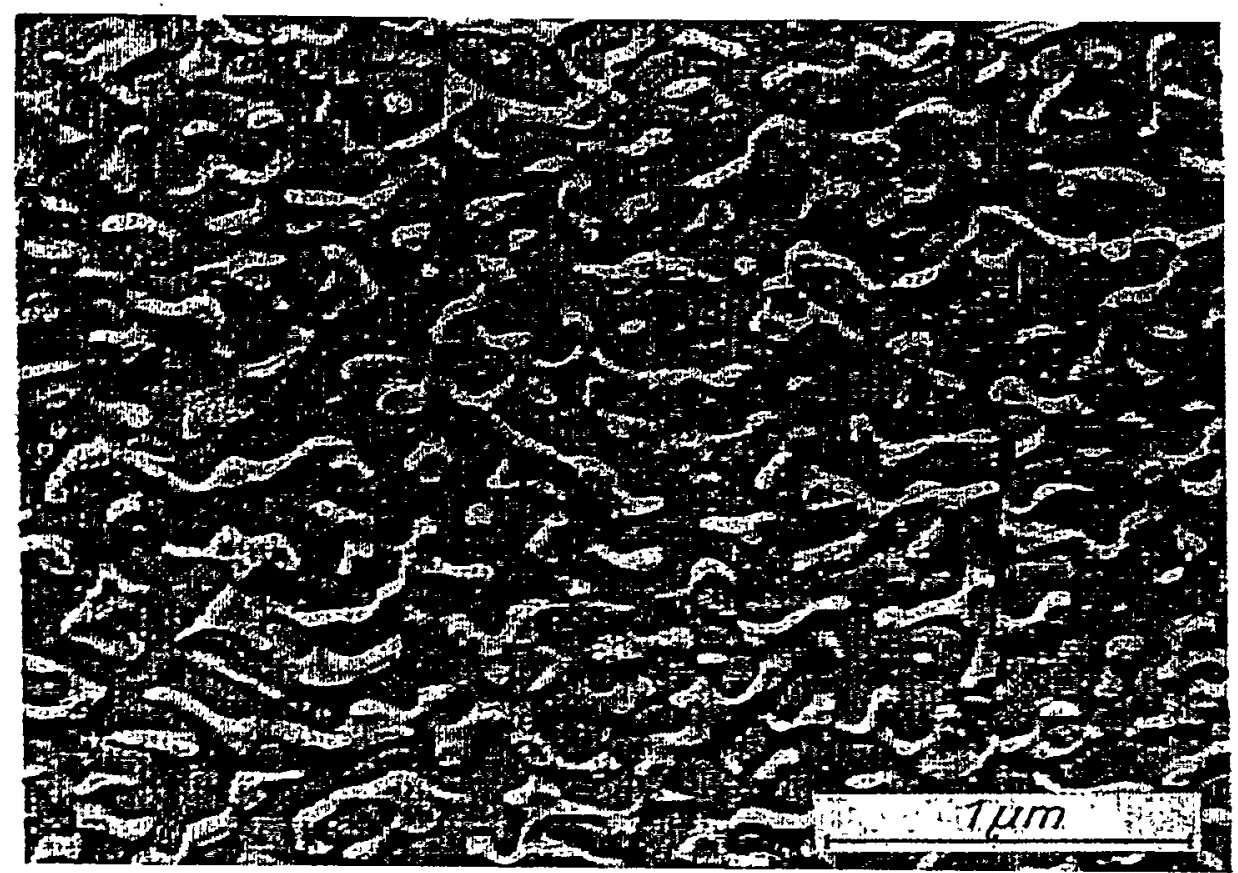

A - Type A phase separation

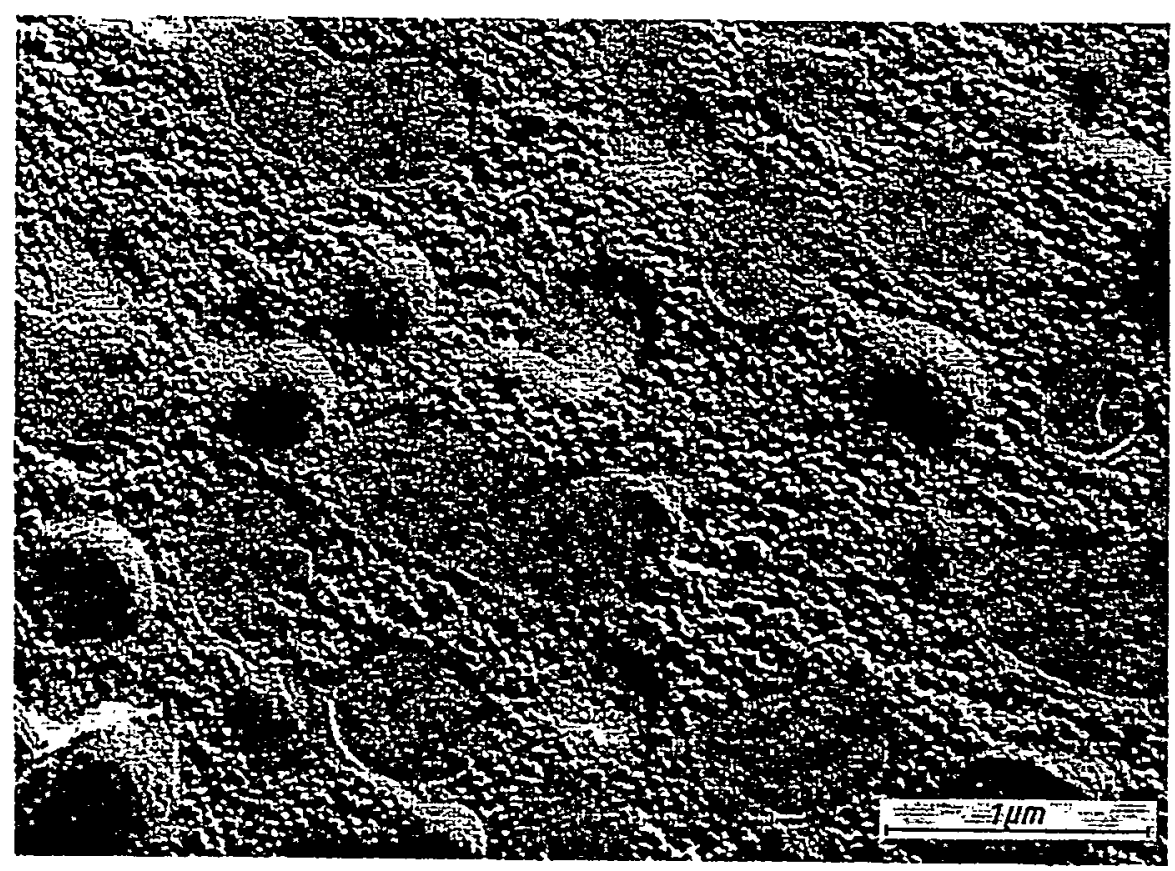

B - Type B phase separation

Figure 1. Examples of Types A,B,C phase separation (described above) in sodium borosilicate glass ${ }^{6}$. 


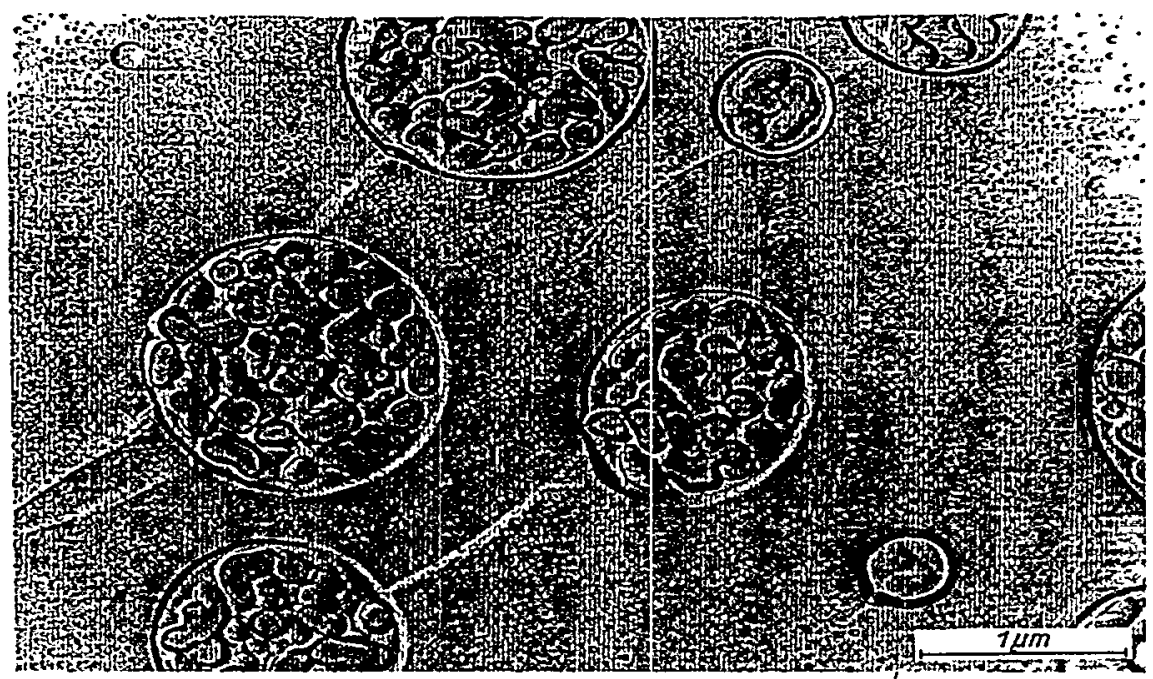

$\mathrm{C}$ - Type $\mathrm{C}$ phase separation

Figure 1., continued.

Multi-component borosilicate glasses such as the SRS DWPF glasses tend to phase separate in manners similar to the alkali borosilicates but there are fewer studies related to these complex 19 component glasses. Additional background information on phase separation in general, and in multicomponent waste glasses can be found in publications by Jantzen, et $\mathrm{al}^{5,8,9,10,11,12}$, Hrma, et al., ${ }^{3}$ and Peeler and $\mathrm{Hrma}^{13}$. Jantzen also examined the role of phosphate phase separation in borosilicate waste glasses as early as $1986 .^{14}$

\subsection{OBJECTIVES}

Previous studies pertaining to phase separation in DWPF type borosilicate waste glasses with little or no phosphate have examined whether phase separation in borosilicate waste glasses occurred at the melt temperature, e.g. would a given glass phase separate macroscopically into two different layers in a melter, or microscopically. Either type, or a mixture of both, could impact glass durability. Because phase separation is a very rapid phenomenon kinetically, some of the glasses previously studied had been rapidly quenched to "freeze in" any melt temperature phase separation. Others had been poured into small stainless steel cans during pilot scale melter campaigns in the SRS Integrated DWPF Melter System (IDMS) and cooled more slowly (see Figure 3 for the cooling regime at the top surface of the IDMS type canister). Some of the glasses (primarily pure frits) exhibited Type B phase separation on a microscopic scale even with the most rapid cooling (pan quenched). Since the cooling in larger $10 \mathrm{ft}$ tall by $2 \mathrm{ft}$ diameter full scale DWPF canisters is somewhat slower, the phase separation may be enhanced (aged or coarsened into larger scale phase separation) when slowly cooled. To study the kinetic effects of coarsening on phase separation in SRS-DWPF full-scale canisters, experiments were designed to indicate which of the time and temperature (cooling rate) scenarios shown in Figure 2 were most probable. The results of these experiments are given in Section 5 of this report.

The INEEL vitrification process and canister design are less evolved and the phase separation is of a type that transforms so rapidly to a crystalline form that amorphous glass-in-glass phase separation cannot easily be studied. Data was taken from the INEEL waste glass composition variability study ${ }^{15}$ and the phase separated phases identified by $\mathrm{x}$-ray diffraction (XRD). A database of these glass compositions and data from high $\mathrm{P}_{2} \mathrm{O}_{5}, \mathrm{Al}_{2} \mathrm{O}_{3}$, and $\mathrm{Na}_{2} \mathrm{O}$ waste glass produced at SRS was compiled. The durability of all these glasses was tested using ASTM. C1285-94 and measured glass compositions were available. Literature data was also surveyed. A statistical analysis of the effects of phosphate on phase separation and durability was performed and appears in Section 5.4 of this report. 


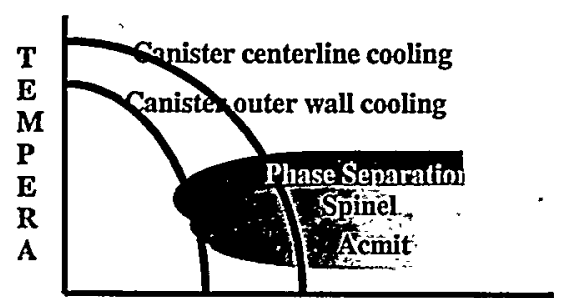

A
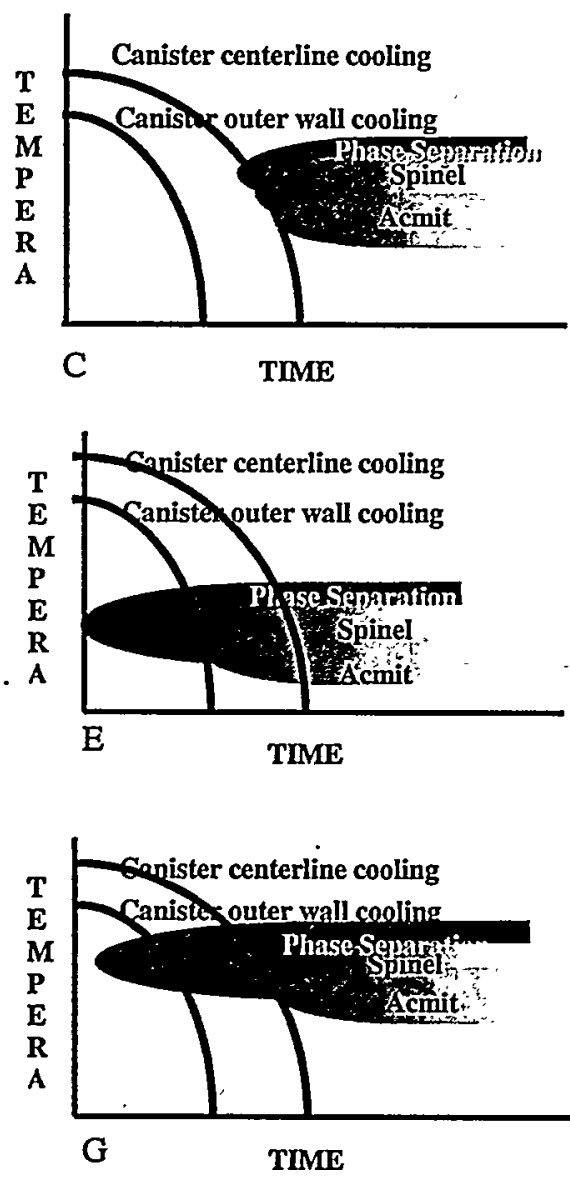
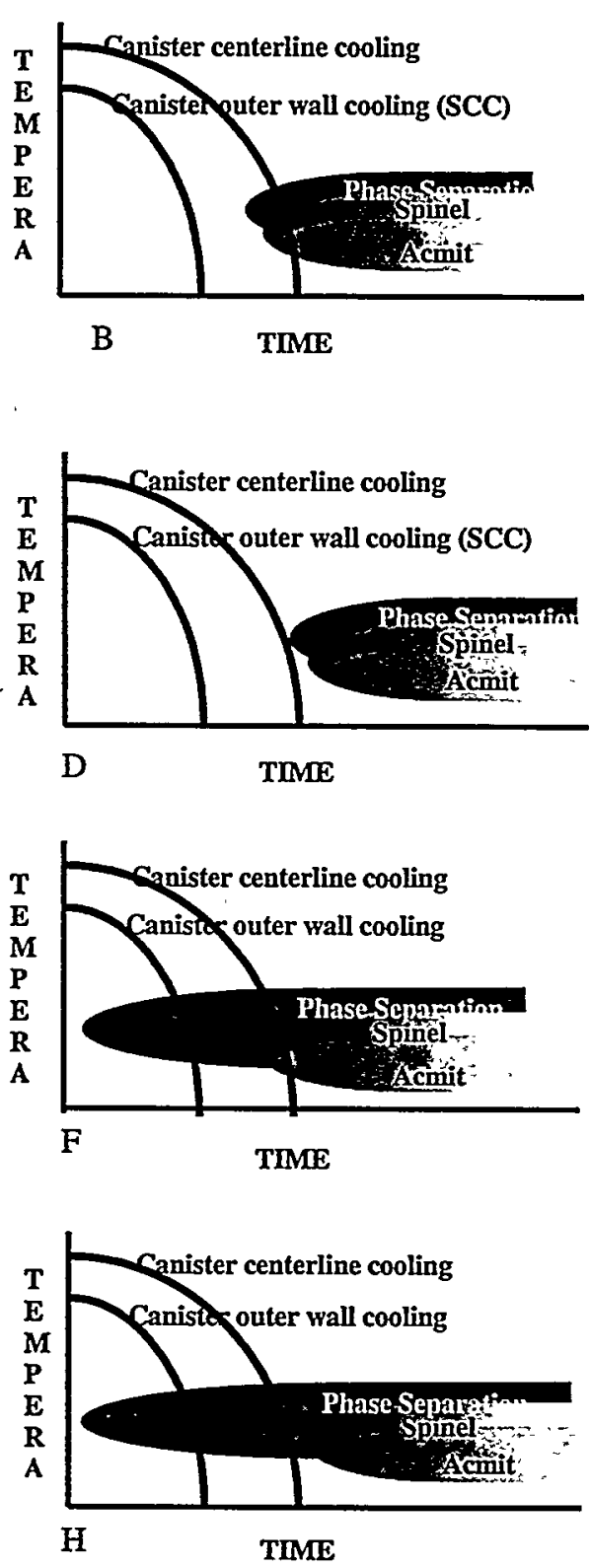

Figure 2. Potential time-temperature transformation (TTT) relationships between phase separation and crystallization in DWPF-type glasses. 


\subsection{EXPERIMENTAL}

\section{Materials and Methods}

Various DWPF glasses were subjected to two cooling regimes (simulated canister surface (SCC) and centerline.(CLC) cooling) in an effort to determine the type of phase separation, the extent of phase separation (if any), and the impact of phase separation on the glass durability. Composition and cooling rates of the glasses were varied. The glasses selected for the study were the DWPF Waste Compliance Plan (WCP) glasses and included, the WCP-Purex which represents Frit 202 loaded with 28 wt\% simulated high $\mathrm{Fe}_{2} \mathrm{O}_{3}$ containing sludge and $8 \mathrm{wt} \%$ precipitate hydrolysis product (PHP), the WCP-HM glass which represents Frit 202 loaded with 28 wt\% simulated high $\mathrm{Al}_{2} \mathrm{O}_{3}$ containing sludge, and the WCP-Blend glass which is an intermediate (average) composition between the Purex and HM formulations. The glass compositions are listed in Table 1. The laboratory furnace programming schedules are shown in Figure 3A. The pan-quench, CLC, SCC along with several other cooling curve graphs (for comparison) are shown in Figure 3B.

Prior to melting, the WCP glasses (Purex, HM and Blend), were crushed, sieved and mixed in varying proportions with excess 202 frit as shown in Table 2. Frit 202 was chosen since the frit itself is known to be phase separated and the addition of excess frit to an already homogeneous glass will at some point cause it to phase separate (e.g. cross the immiscibility boundary in multicomponent composition space). Each test used 20 grams of material with the exception of the runs vitrified for the Product Consistency Test (PCT - ASTM 1285-94), where 50 grams of material was needed. Platinum/gold crucibles were used for all experiments. Upon completion of the cooling schedule, the glasses were removed from the crucibles. Each specimen was cut in half and a thin slice was removed from one the halves as shown in Figure 4. The thin section was mounted to a microscope slide, polished and examined

Table 1. Average Glass Compositions for the Phase Separation Experiments (in wt $\%)^{16}$.

\begin{tabular}{|c|c|c|c|c|}
\hline Component & WCP-Blend (wt\%) & WCP-HM (wt\%) & WCP-Purex (wt\%) & Frit 202 (wt\%) \\
\hline $\mathrm{Al}_{2} \mathrm{O}_{3}$ & 4.16 & 7.15 & 2.99 & 0.40 \\
\hline $\mathrm{CaO}$ & 1.03 & 1.01 & 1.09 & 0.10 \\
\hline $\mathrm{Fe}_{2} \mathrm{O}_{3}$ & 10.91 & 7.78 & 13.25 & -- \\
\hline $\mathrm{MgO}$ & 1.41 & 1.49 & 1.41 & 1.90 \\
\hline $\mathrm{MnO}$ & 1.67 & 1.75 & - & - \\
\hline $\mathrm{Na}_{2} \mathrm{O}$ & 9.13 & 8.56 & 12.62 & 5.80 \\
\hline $\mathrm{Li}_{2} \mathrm{O}$ & 4.44 & 4.62 & 3.22 & 6.60 \\
\hline $\mathrm{NiO}$ & 0.89 & 0.41 & 1.19 & -- \\
\hline $\mathrm{SiO}_{2}$ & 51.90 & 55.80 & 46.50 & 77.04 \\
\hline $\mathrm{Cr}_{2} \mathrm{O}_{3}$ & 0.13 & 0.09 & 0.15 & - \\
\hline $\mathrm{B}_{2} \mathrm{O}_{3}$ & 8.05 & 7.03 & 10.33 & 7.81 \\
\hline $\mathrm{ZrO}_{2}$ & 0.14 & 0.33 & 0.05 & -- \\
\hline $\mathrm{TiO}_{2}$ & 0.89 & 0.56 & 0.68 & 0.10 \\
\hline $\mathrm{K}_{2} \mathrm{O}$ & 3.68 & 2.21 & 3.41 & 0.30 \\
\hline $\mathrm{Cs}_{2} \mathrm{O}$ & 0.08 & 0.06 & 0.06 & -- \\
\hline $\mathrm{Na}_{2} \mathrm{O}_{3}$ & 0.22 & 0.55 & 0.06 & - \\
\hline $\mathrm{BaO}_{\mathrm{MoO} O}$ & 0.18 & 0.11 & 0.20 & -- \\
\hline $\mathrm{CuO}_{\mathrm{Cu}} \mathrm{O}$ & 0.15 & 0.22 & 0.08 & -- \\
\hline $\mathrm{Total}$ & 0.22 & 0.13 & 0.21 & -- \\
\hline & 0.20 & 0.11 & 0.19 & -- \\
\hline & 99.48 & 99.97 & 99.37 & 100.05 \\
\hline
\end{tabular}




\section{CENTERLINE CANISTER COOLING (CLC)}

$\begin{array}{lllllllll}\text { Temperature }\left({ }^{\circ} \mathrm{C}\right) & 1150 & 926 & 779 & 715 & 598 & 490 & 382 & 70\end{array}$

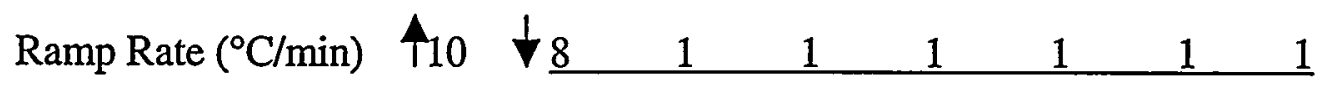

\begin{tabular}{lllllllll} 
Hold Time (hrs) & 4 & 0.1 & 2.8 & 3.4 & 4.2 & 4.3 & 7.4 & end \\
\hline
\end{tabular}

\section{SURFACE CANISTER COOLING (SCC)}

$\begin{array}{llllll}\text { Temperature }\left({ }^{\circ} \mathrm{C}\right) & 1150 & 475 & 400 & 325 & 75\end{array}$

Ramp Rate $\left({ }^{\circ} \mathrm{C} / \mathrm{min}\right) \quad \uparrow_{10}$ samples moved to $\downarrow^{0.06} \quad 0.42 \quad 0.126$

\begin{tabular}{llllll} 
Hold Time (hrs) & 4 & 0.33 & 0.08 & 0.08 & end \\
\hline
\end{tabular}

A

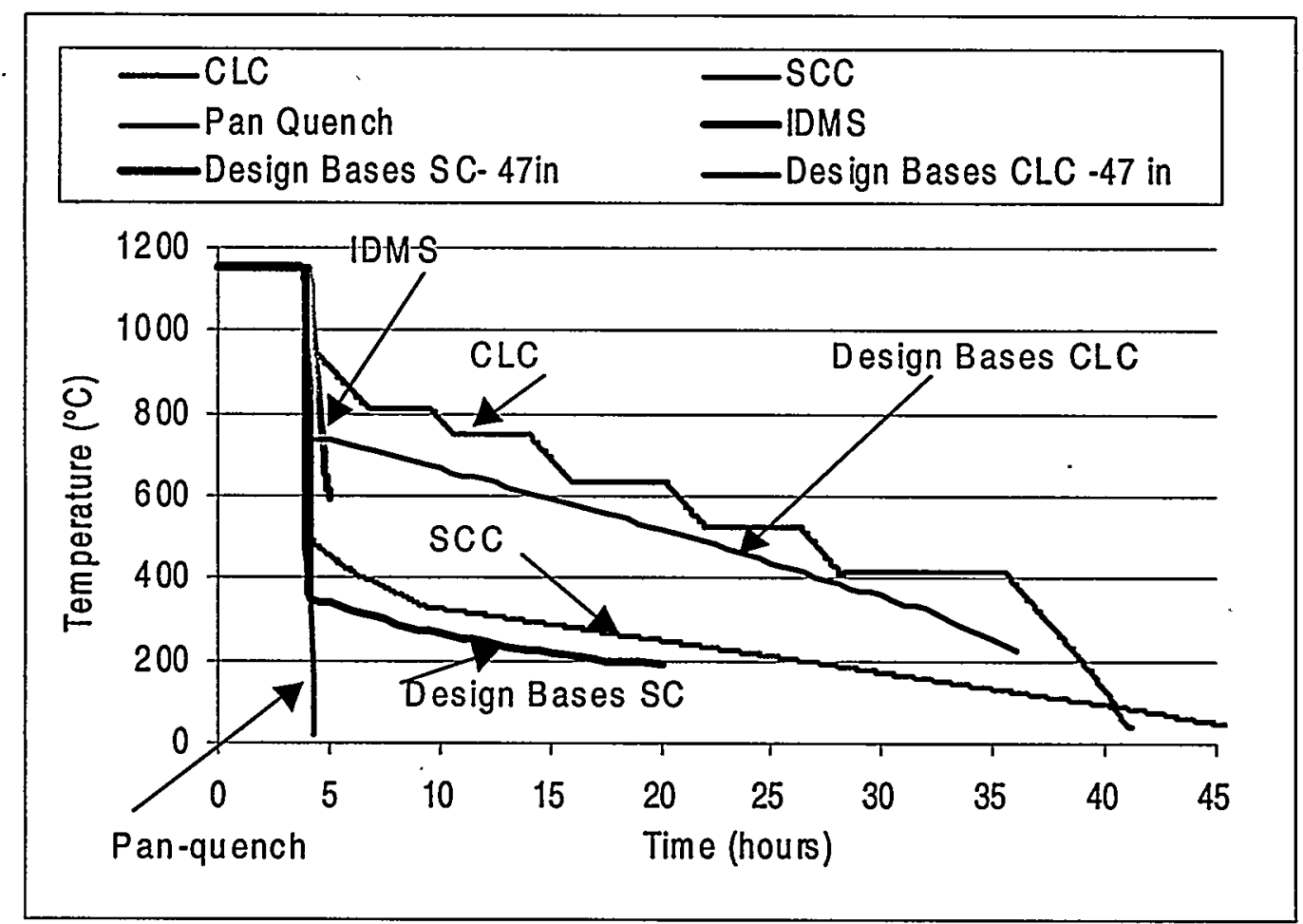

B

Figure 3. A) Centerline and surface cooling furnace programming schedules ${ }^{17}$. B) Cooling rate curves $^{18,19}$. 
Table 2. Basic Test Matrix Showing Glass Types and Mixtures for the Two Cooling Schediules.

\begin{tabular}{|c|c|c|c|c|c|c|c|c|c|}
\hline Mix & \multicolumn{8}{|c|}{ Weight Percent (Wt\%) } & \multirow{2}{*}{$\begin{array}{l}\begin{array}{l}\text { Cooling } \\
\text { Schedule }\end{array} \\
\text { CLC }\end{array}$} \\
\hline \multirow[t]{2}{*}{ WCP-Purex/202 } & $100 / 0$ & $90 / 10$ & $80 / 20$ & $70 / 30$ & $60 / 40$ & $40 / 60$ & $20 / 80$ & $0 / 100$ & \\
\hline & -- & $90 / 10$ & $80 / 20$ & $70 / 30$ & $60 / 40$ & $40 / 60$ & $20 / 80$ & -- & SCC \\
\hline \multirow[t]{2}{*}{ WCP-HM/202 } & $100 / 0$ & $90 / 10$ & $80 / 20$ & $70 / 30$ & $60 / 40$ & $40 / 60$ & $20 / 80$ & $0 / 100$ & CLC \\
\hline & -- & $90 / 10$ & $80 / 20$ & $70 / 30$ & $60 / 40$ & $40 / 60$ & $20 / 80$ & - & SCC \\
\hline \multirow[t]{2}{*}{ WCP-BL/202 } & $100 / 0$ & $90 / 10$ & $80 / 20$ & $70 / 30$ & $60 / 40$ & $40 / 60$ & $20 / 80$ & $0 / 100$ & CLC \\
\hline & - & $90 / 10$ & $80 / 20$ & $70 / 30$ & $60 / 40$ & $40 / 60$ & $20 / 80$ & $-\cdots$ & SCC \\
\hline
\end{tabular}

\section{Remove from Remove thin crucible \\ Cut in half section}
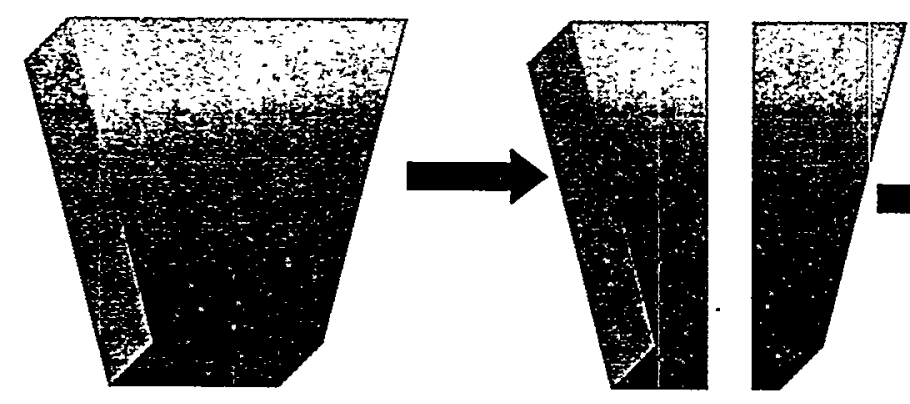

Polish

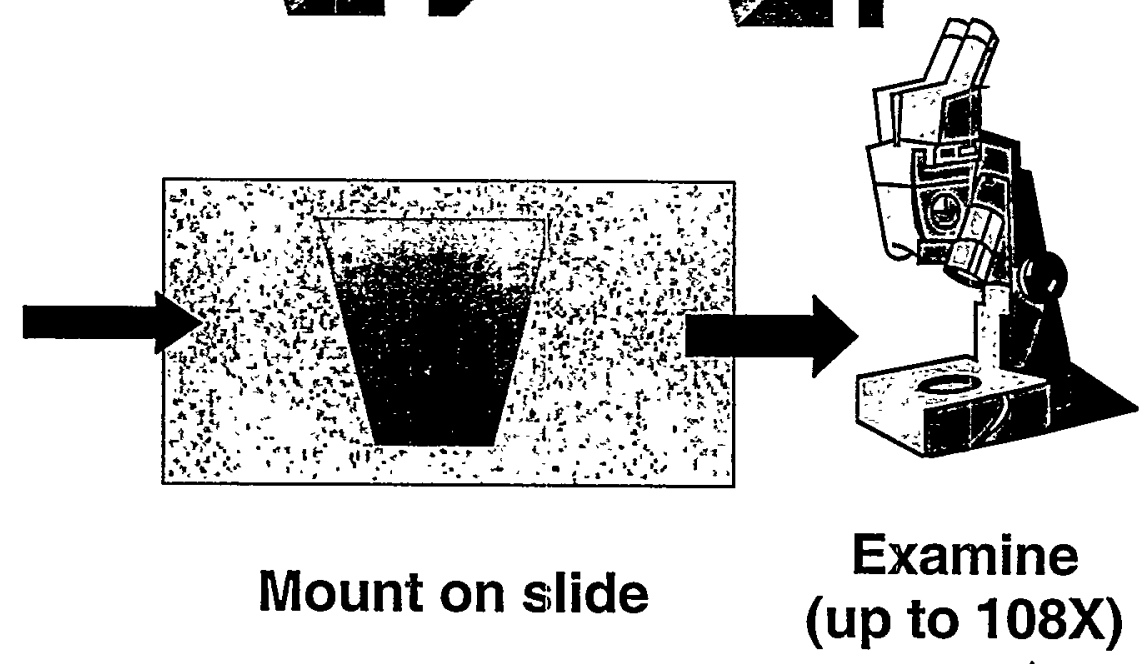

Figure 4. Preparation for examining glass samples using optical microscopy. 
WSRC-TR-2000-00010, Revision 0

using an optical microscope. The remaining glass sections were submitted for density measurements and in some cases, compositional analyses. Selected glasses were examined using scanning electron microscopy with energy dispersive spectroscopy (SEM/EDS) and/or x-ray diffraction.

\subsection{RESULTS}

\subsection{Microscopy}

The results of the optical (OM), scanning electron and transmission electron (TEM) microscopic examination of the WCP/202 glasses along with durability data are shown in Figures 5-13. The first set of data shows glasses prepared in a previous study ${ }^{20}$ where WCP Purex and Frit 202 were mixed in the same proportions described in the previous section. However, these glasses were rapidly quenched (held at $1150^{\circ} \mathrm{C}$ for four hours, molten glass poured out onto a steel plate and allowed to air cool) rather than following the centerline or surface canister cooling schedules. As can be seen from the swirl/layered effects visible in the optical micrographs (Figure 5), there is evidence to suggest macroscopic phase separation occurred at the melt temperature and was "frozen in" during the rapid cooling. This implies that the phase separation occurs at, or near the melt temperature (stable immiscibility), and that phase separation does not occur upon cooling.

The same compositions were predicted by the DWPF Phase Separation Discriminator (PSD), which is mathematically described as a probability function, to be homogeneous at the 50:50 probability level and/or revealed by TEM (Figure 6) to be homogeneous on a microscopic scale. The PSD predicted at the 50:50 probability level that phase separation could occur in WCP Purex glasses with $\geq 15 w t \%$ excess Frit 202, in WCP Blend 1 glass with $\geq 10$ wt\% excess Frit 202, and in WCP HM glasses with $\geq 15 w t \%$ excess Frit 202 . The macroscopic phase separation observed in this study at $\sim 10 \mathrm{wt} \%$ in all the WCP glasses was predicted by the PSD to be phase separated at $15 \%, 50 \%$, and $20 \%$ probabilities for Purex, Blend 1, and HM glasses, respectively.

In the tests conducted during this study, varying amounts of the WCP-Purex, WCP-HM and WCP-Blend glasses were mechanically mixed with Frit 202 . The glasses were melted at $1150^{\circ} \mathrm{C}$ for 4 hours and then subjected to DWPF simulated canister centerline cooling or surface cooling. As shown in Figure 7, crystals were present in the greatest number in the bottom of the samples and while not clearly shown in these photographs, a layering effect (lighter color glass on the top, darker on bottom) was observed in most of the samples substantiating that macroscopic phase separation appears to be occurring. The glasses that did not exhibit the macroscopic phase separation were the $100 \%$ Purex and $100 \%$ Frit 202.

The 20\% Purex $/ 80 \% 202$ glass mixture was further distinguished by a light green crystalline layer that formed on the surfaces in contact with the crucible after SCC cooling. This crystalline material was identified as cristobalite by $\mathrm{x}$-ray diffraction analysis (XRD). The layering effect is easily identified in some of the micrographs shown in Figure 8 which represents the WCP Purex and Frit 202 mixtures subjected to surface canister cooling. In all cases, the lighter color glass was found at the top of the melt and the darker color glass at the bottom. There was little evidence of crystallization in any of the SCC glasses and the surface crystallization observed in the 20/80 mix that was subjected to the CLC schedule was not observed in the SCC 20/80 mix. Similar trends were observed for the WCP-HM/202 and WCP. Blend/202 glasses as well (Figures 9-12). However, there was a greater degree of crystallinity observed in the WCP-HM and Blend glasses that were subjected to centerline canister cooling than was found in the WCP-Purex glasses. The crystals observed in the HM and Blend glasses subjected to CLC were identified as acmite with a nucleation center of ruthenium or a center consisting of a Ni-Fe spinel (see Figures 13-15 (SEM/EDS)). Crystals were not found in the HM or Blend SCC glasses. However, the layering/swirl effect was still clearly visible. Undissolved solids observed were identified as ruthenium.

From the data gathered thus far, it appears that the most likely TTT scenario would be one where the phase separation nose intersects both the CLC and SCC cooling curves ahead of the spinel and acmite formation. The spinel and acmite noses would intersect the CLC curve at a point in time after the phase 
WSRC-TR-2000-00010, Revision 0
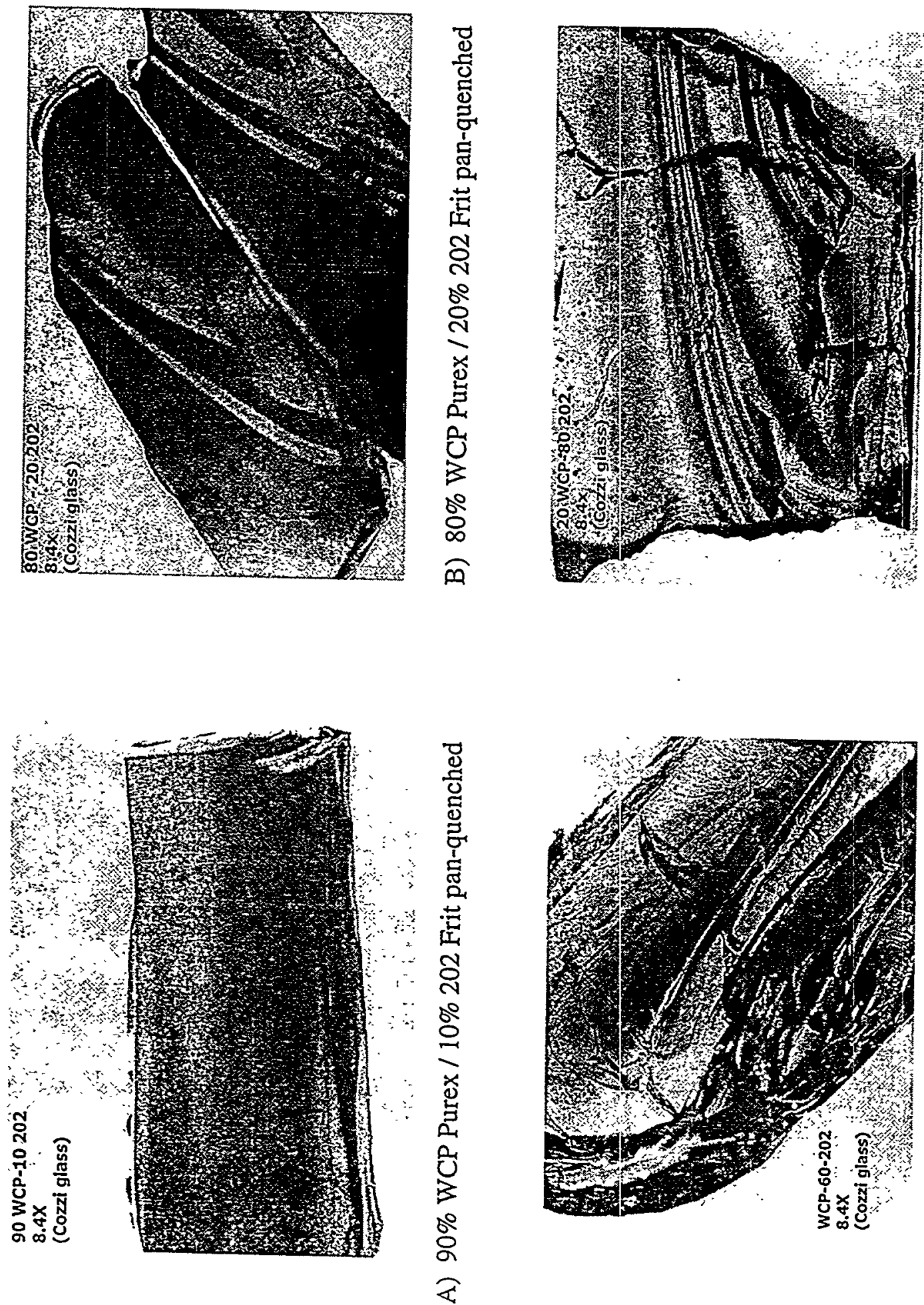

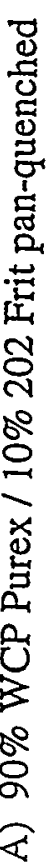
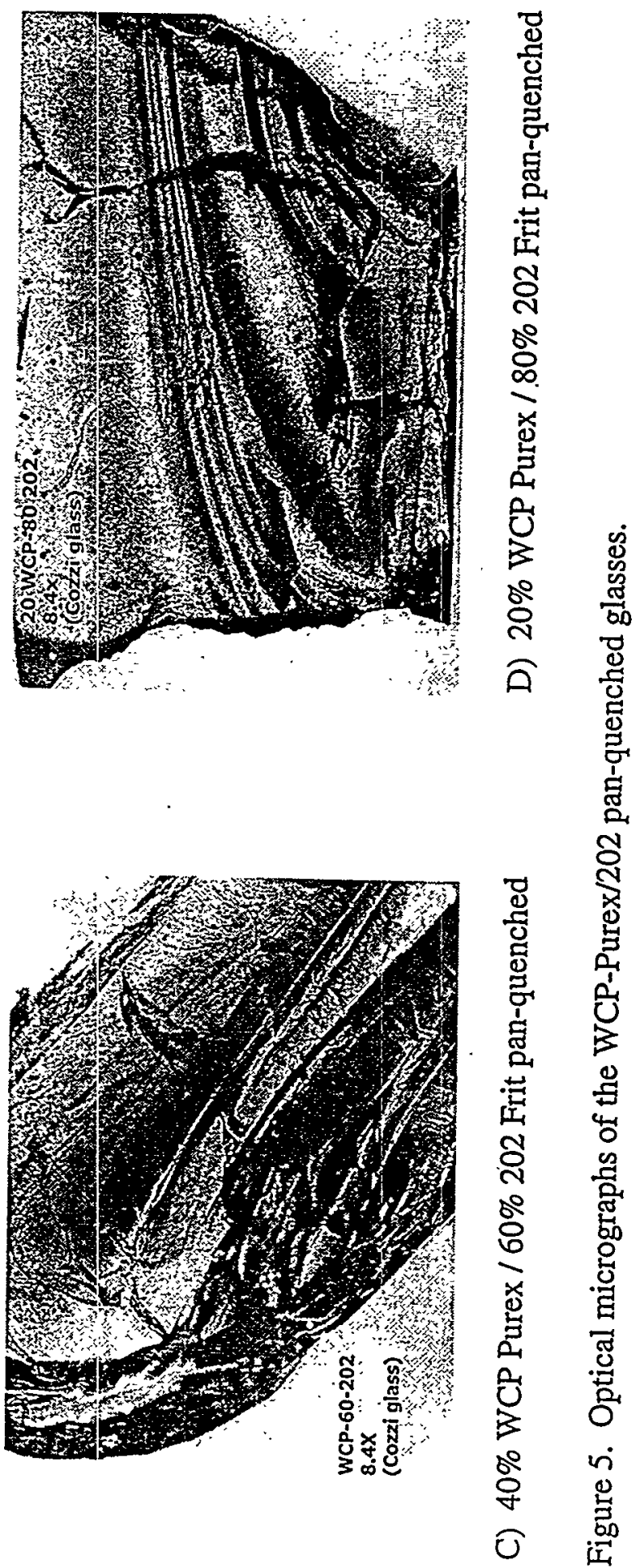
WSRC-TR-2000-00010, Revision 0
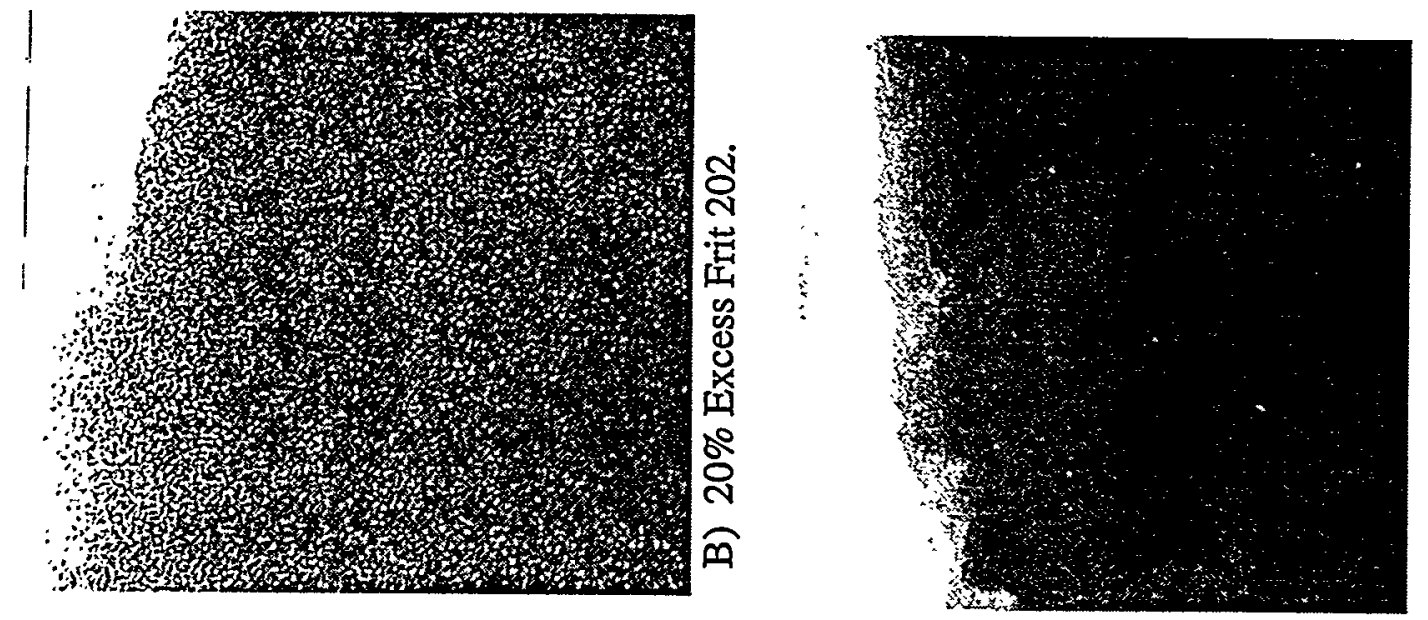

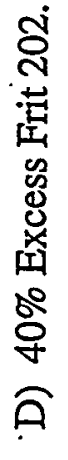
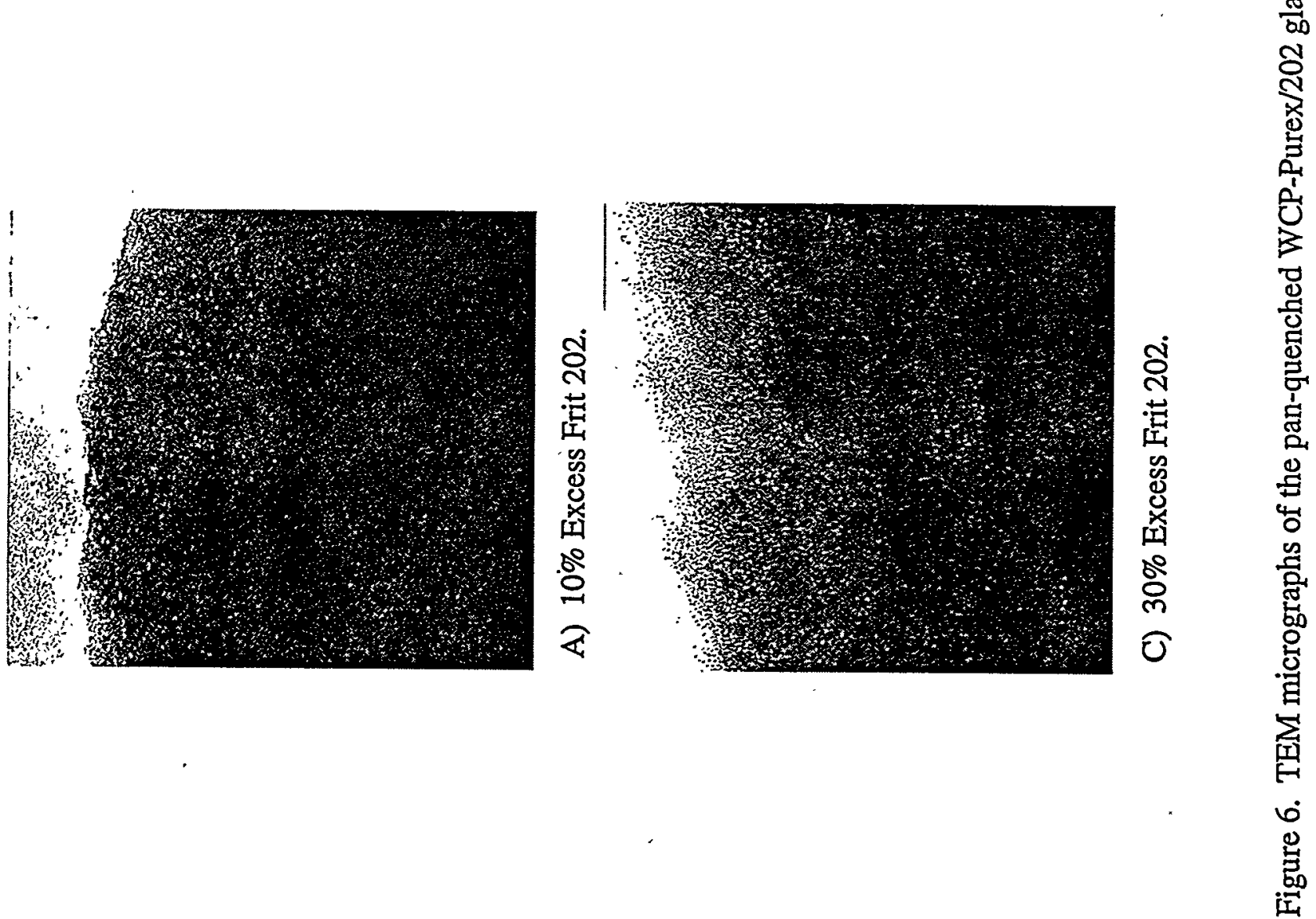

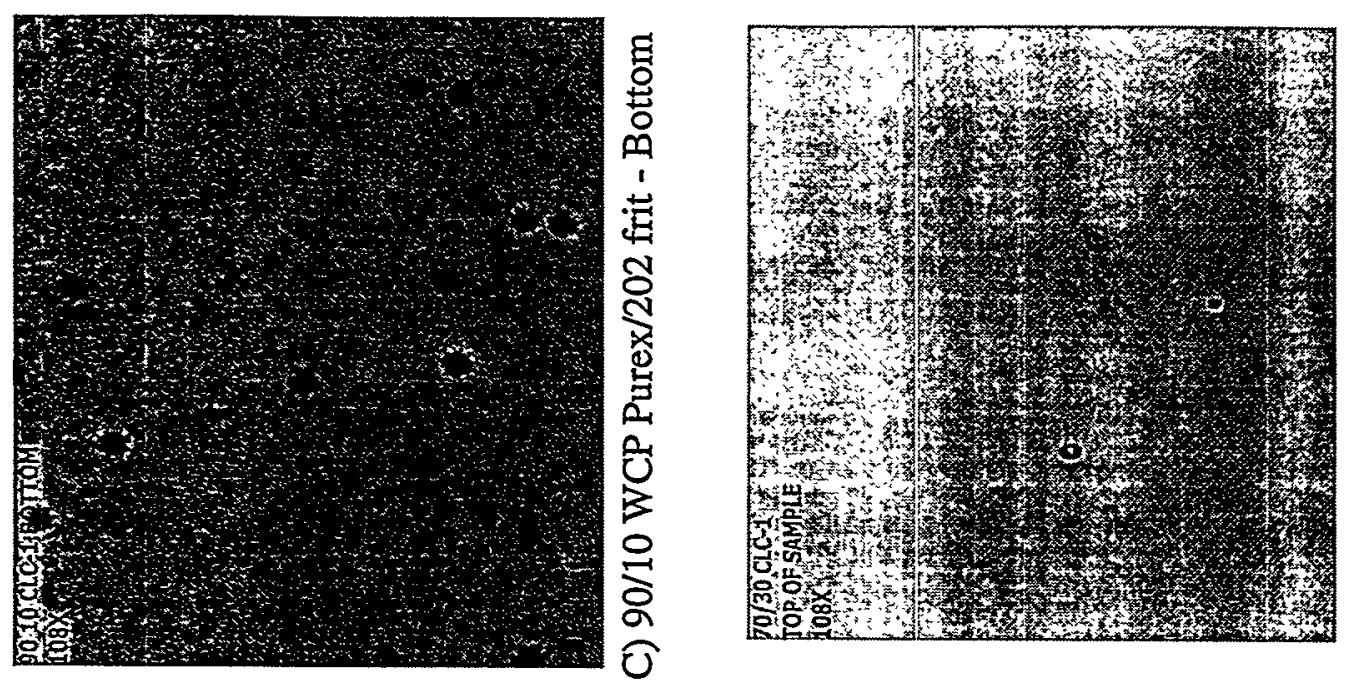

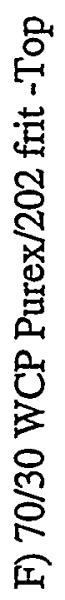

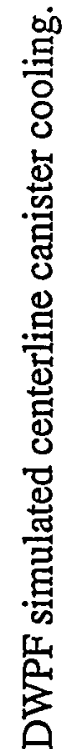
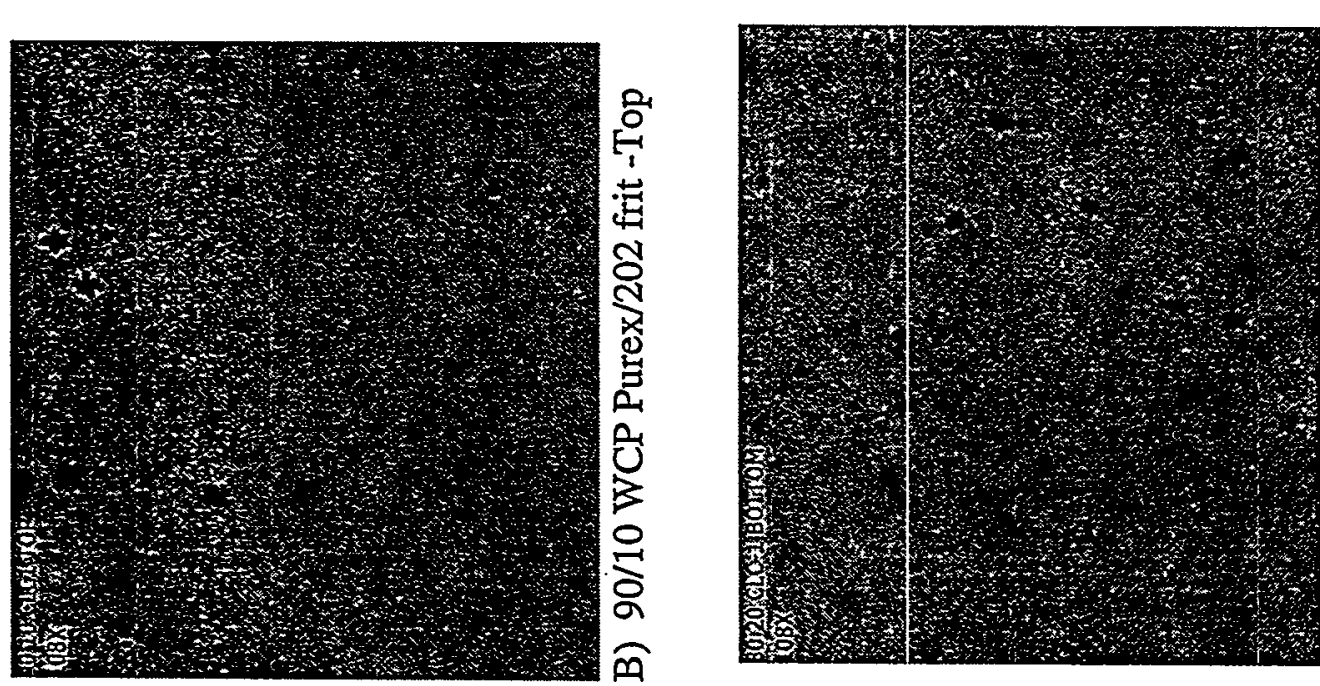

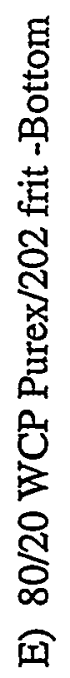
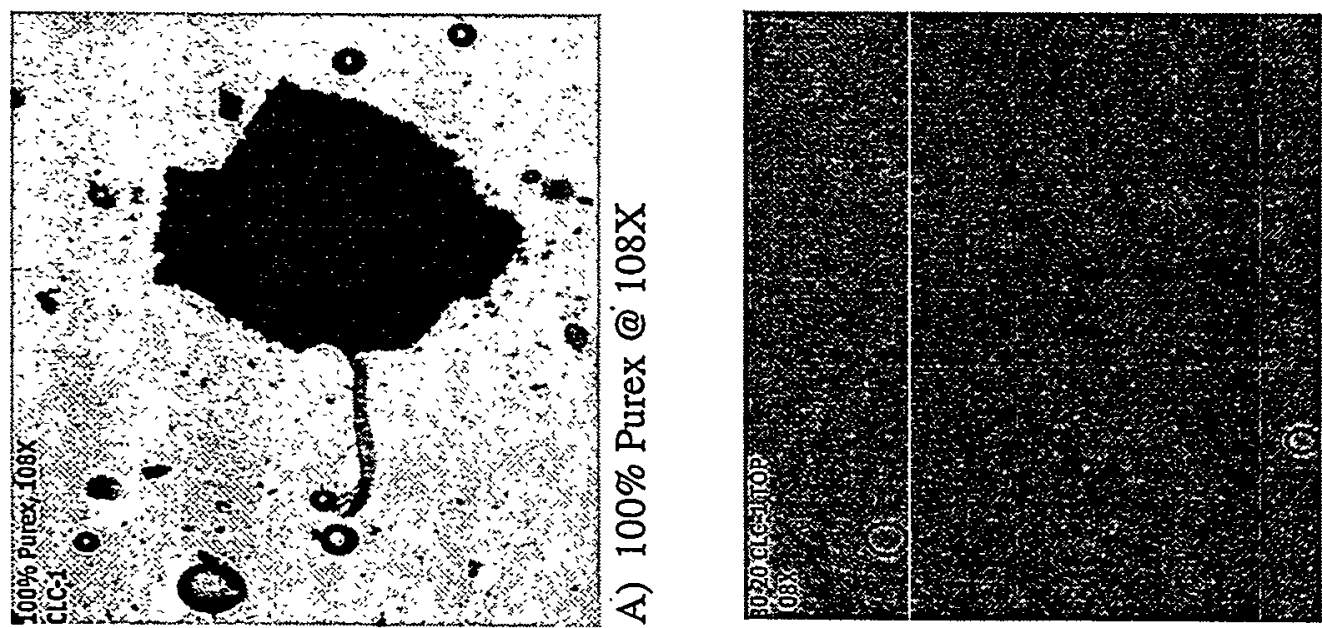



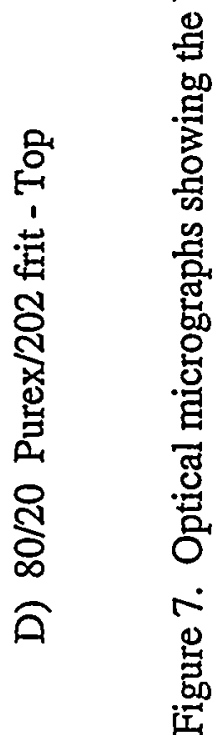


WSRC-TR-2000-00010, Revision 0
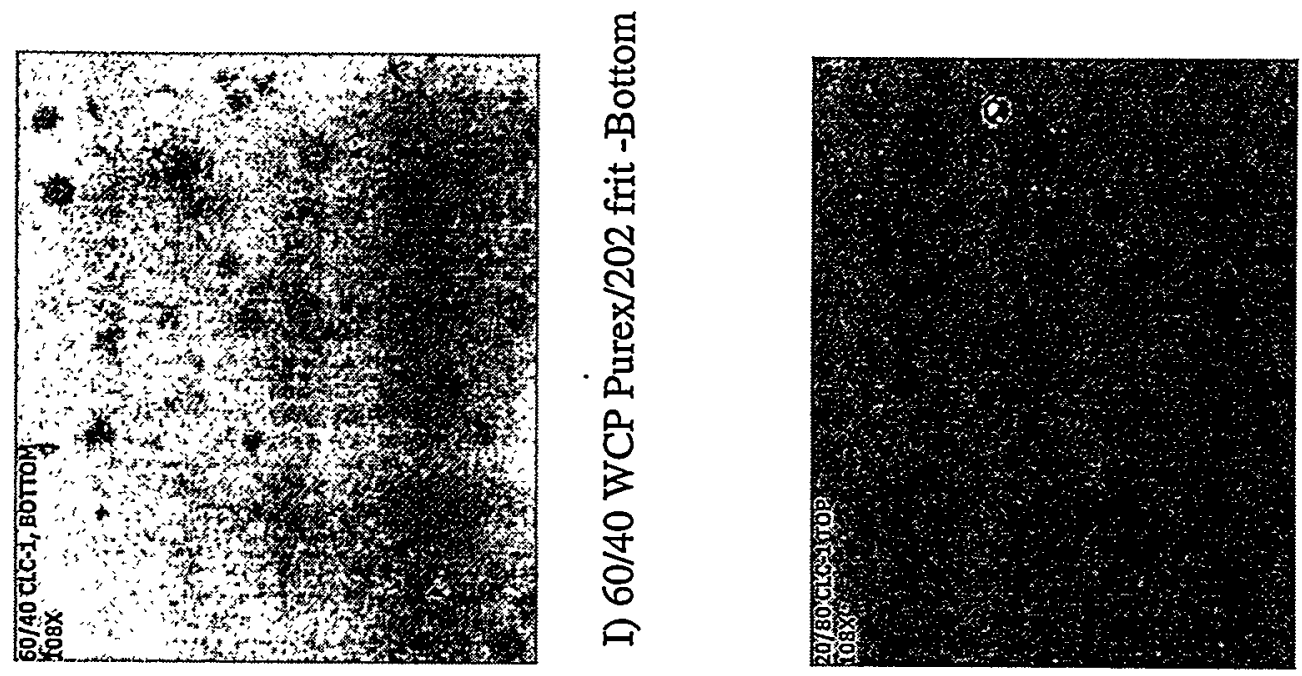

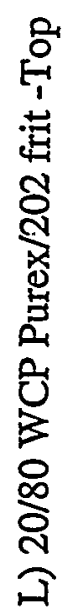

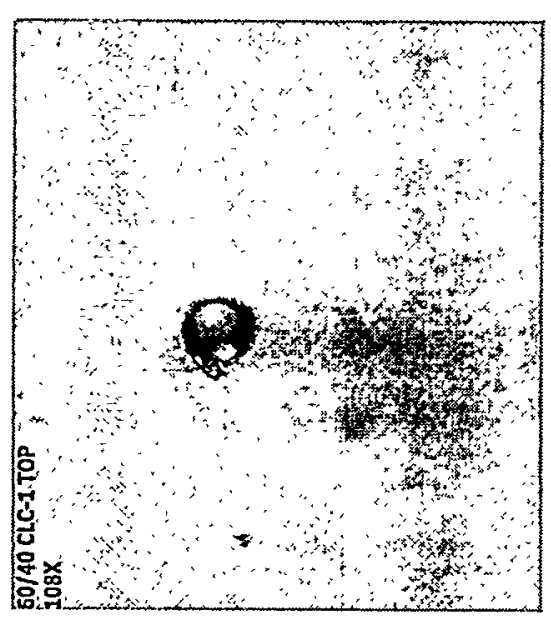

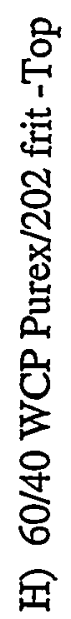
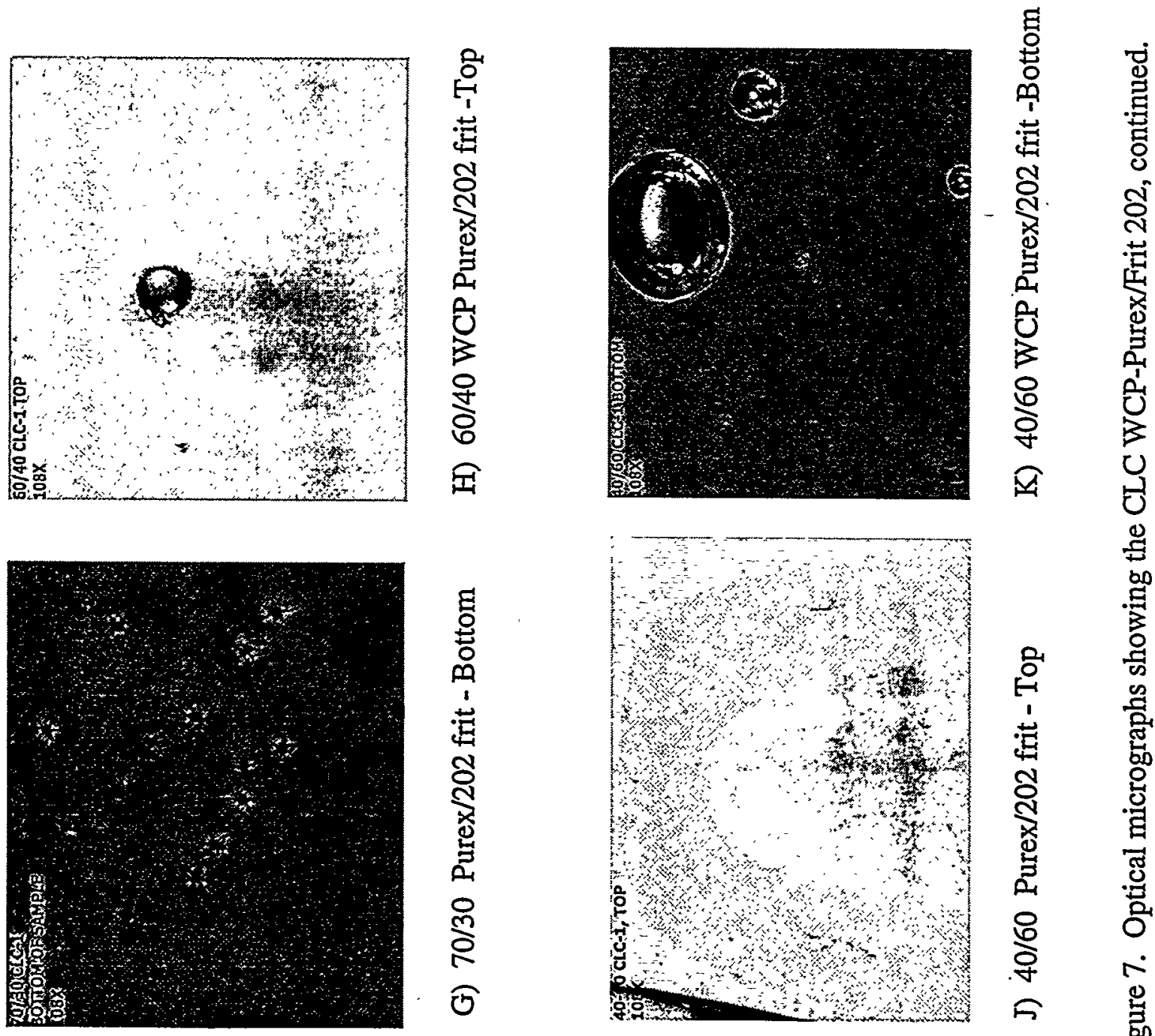

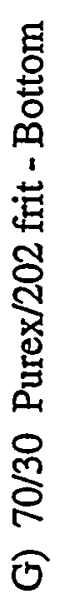

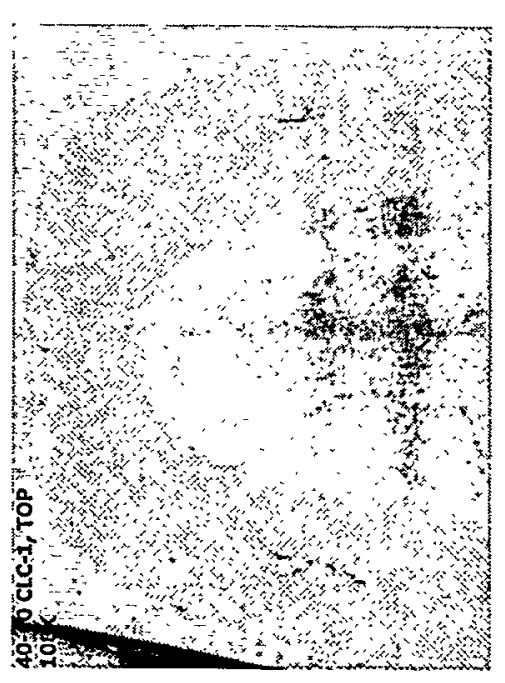

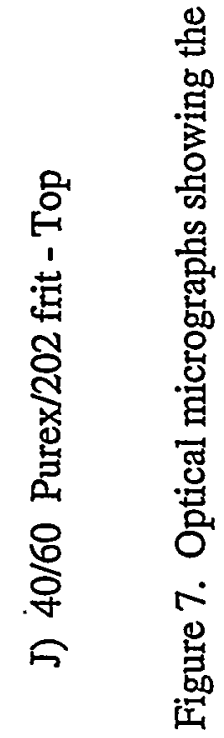


WSRC-TR-2000-00010, Revision 0

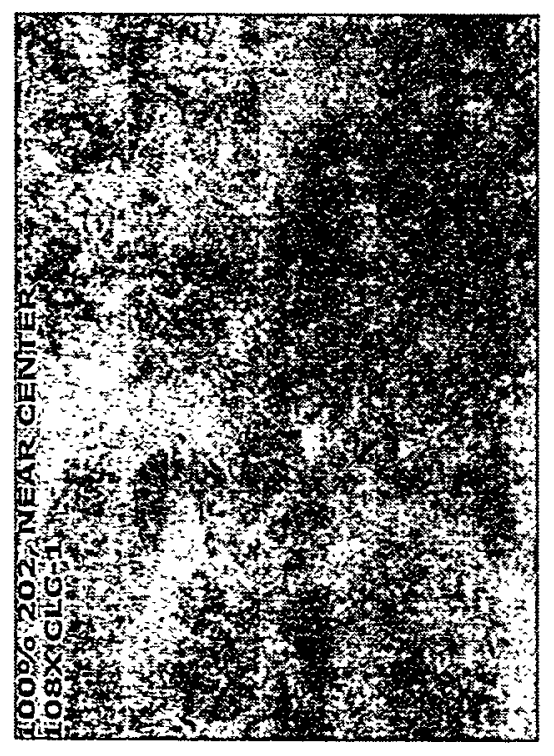

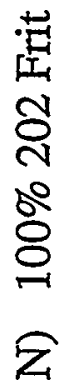

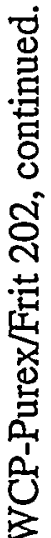

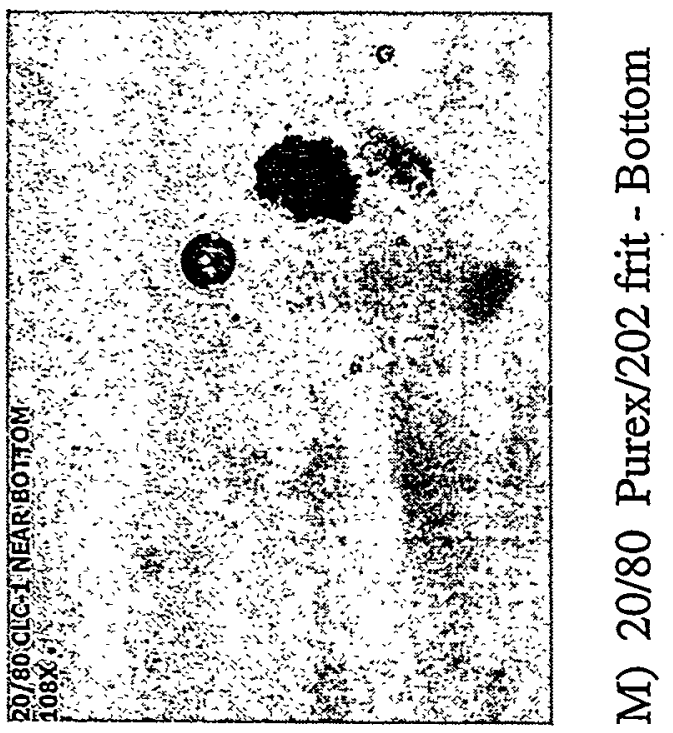

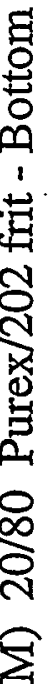




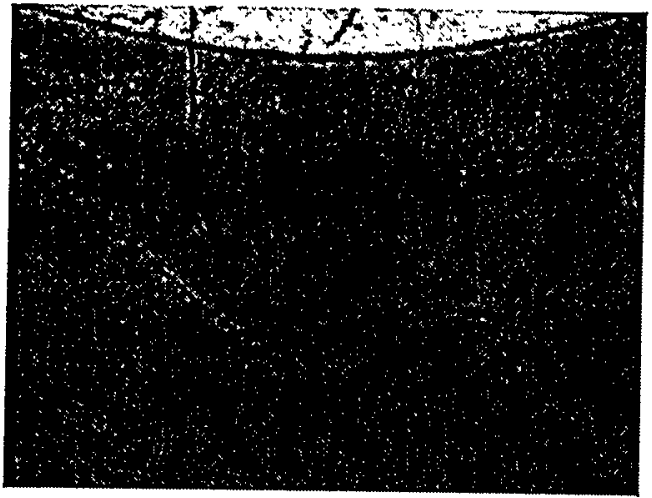

A) $90 / 10$ SCC-1 $8.4 \mathrm{X}$

$\vec{n}$

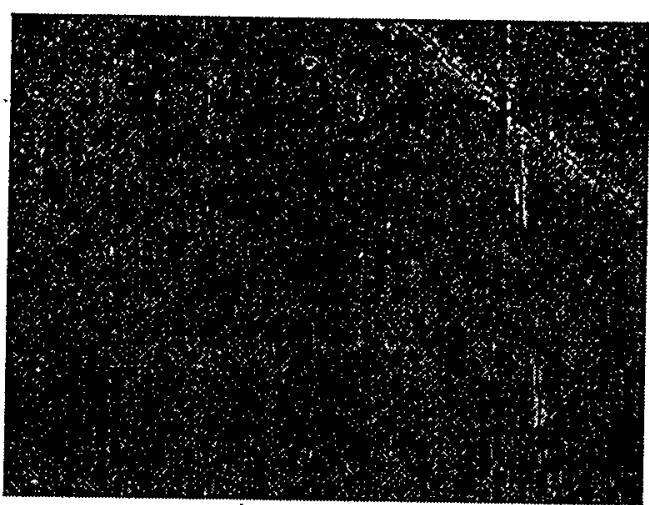

B) $90 / 10$ SCC-1 TOP

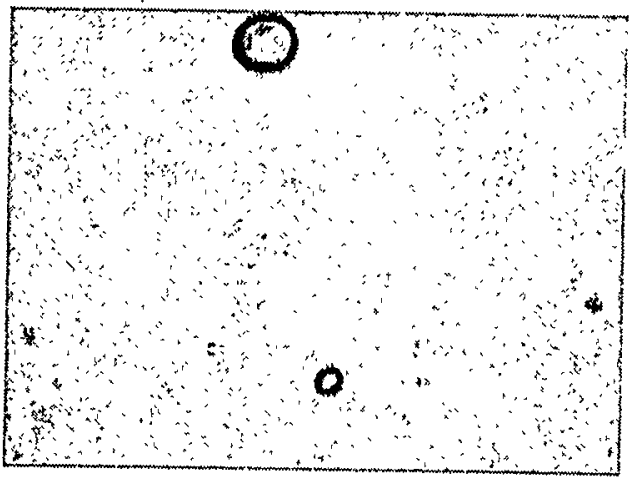

E) $80 / 20$ SCC-1 TOP
C) $90 / 10$ SCC-1 BOTTOM
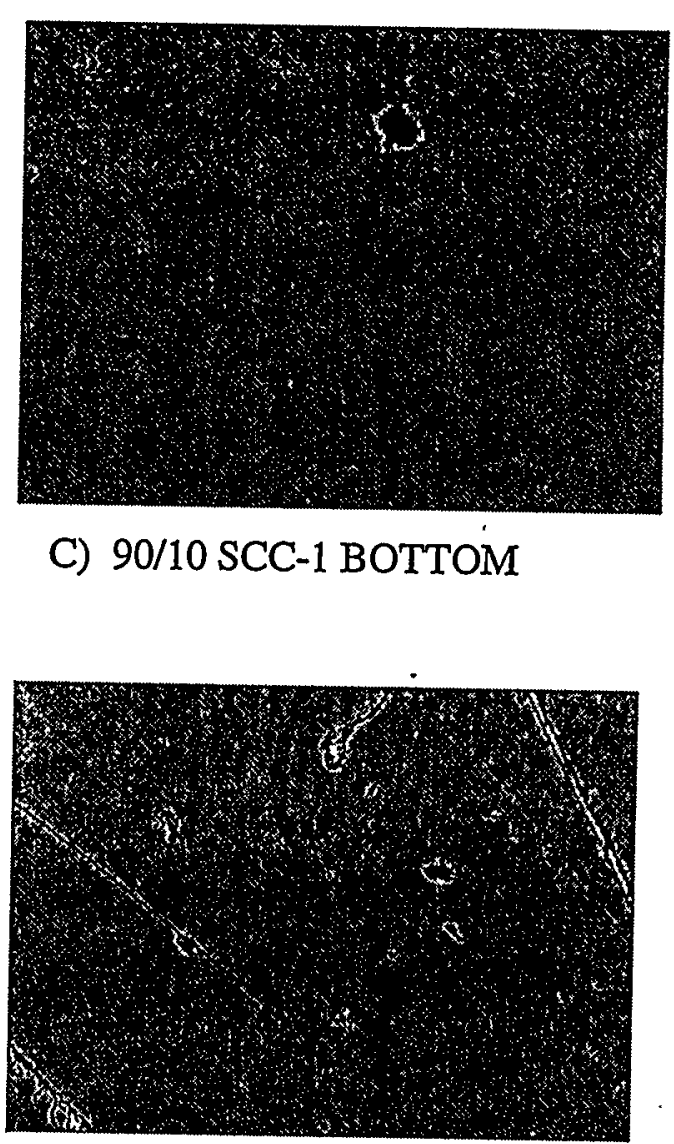

F) $80 / 20$ SCC-1 BOTTOM

Figure 8. Optical micrographs showing the WCP Purex/202 Frit subjected to simulated DWPF surface canister cooling. 

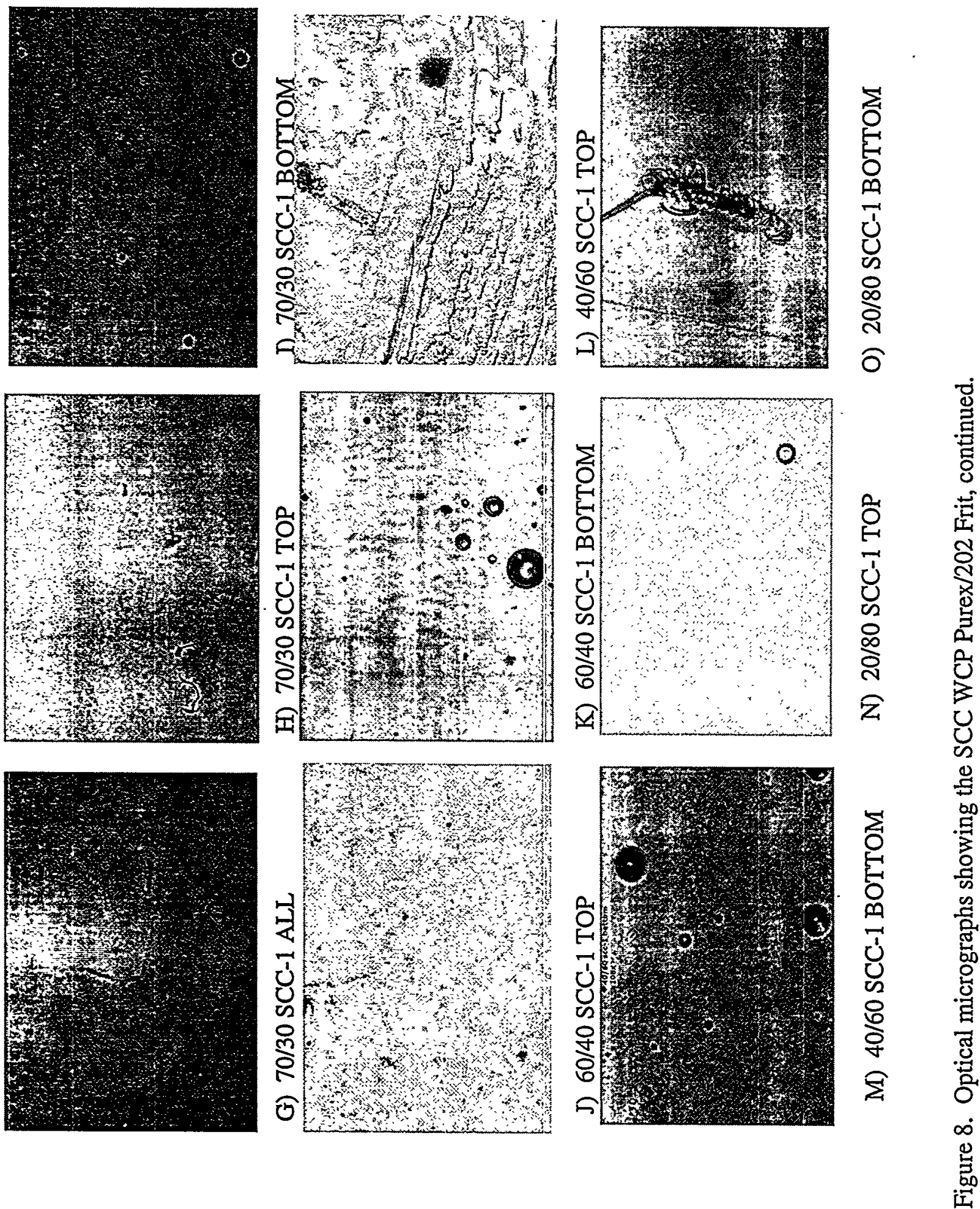

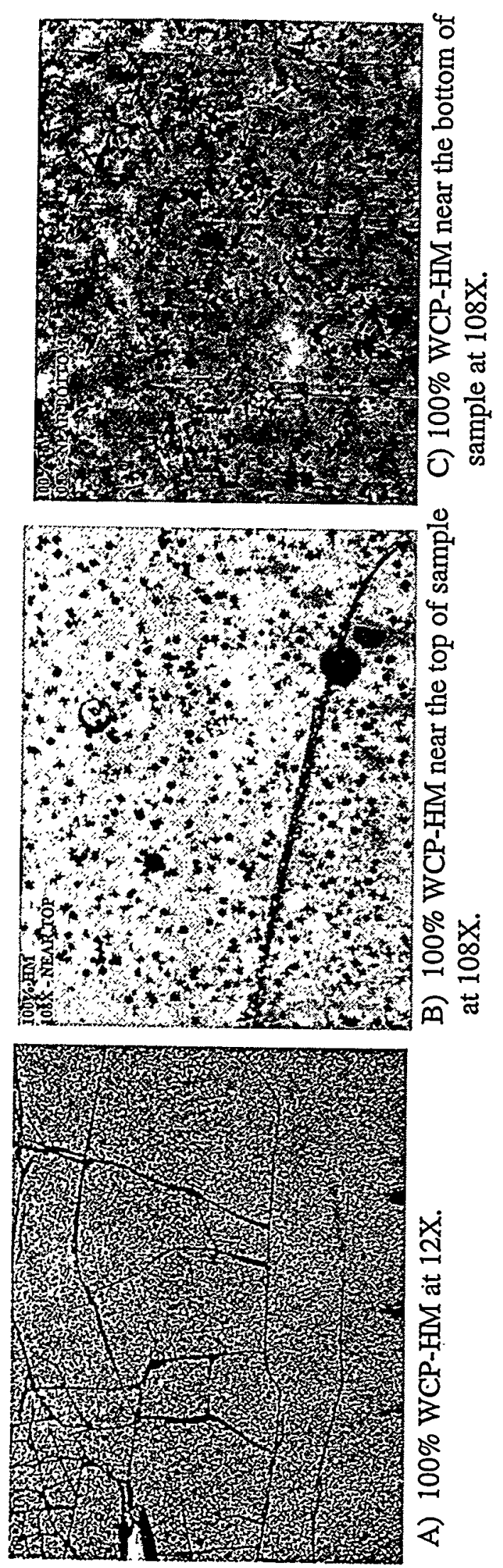
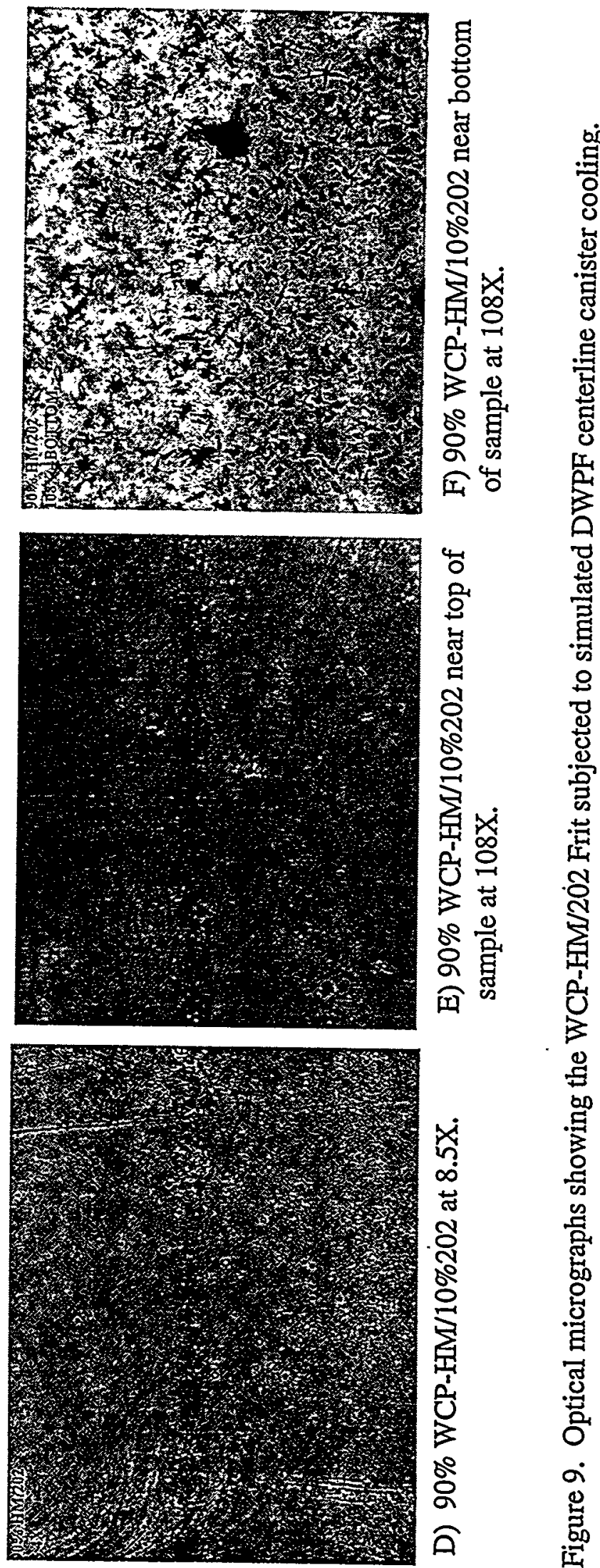

要

옹

营

茄

을

莒

i

్ㅗㅀ

诖 
WSRC-TR-2000-00010, Revision 0
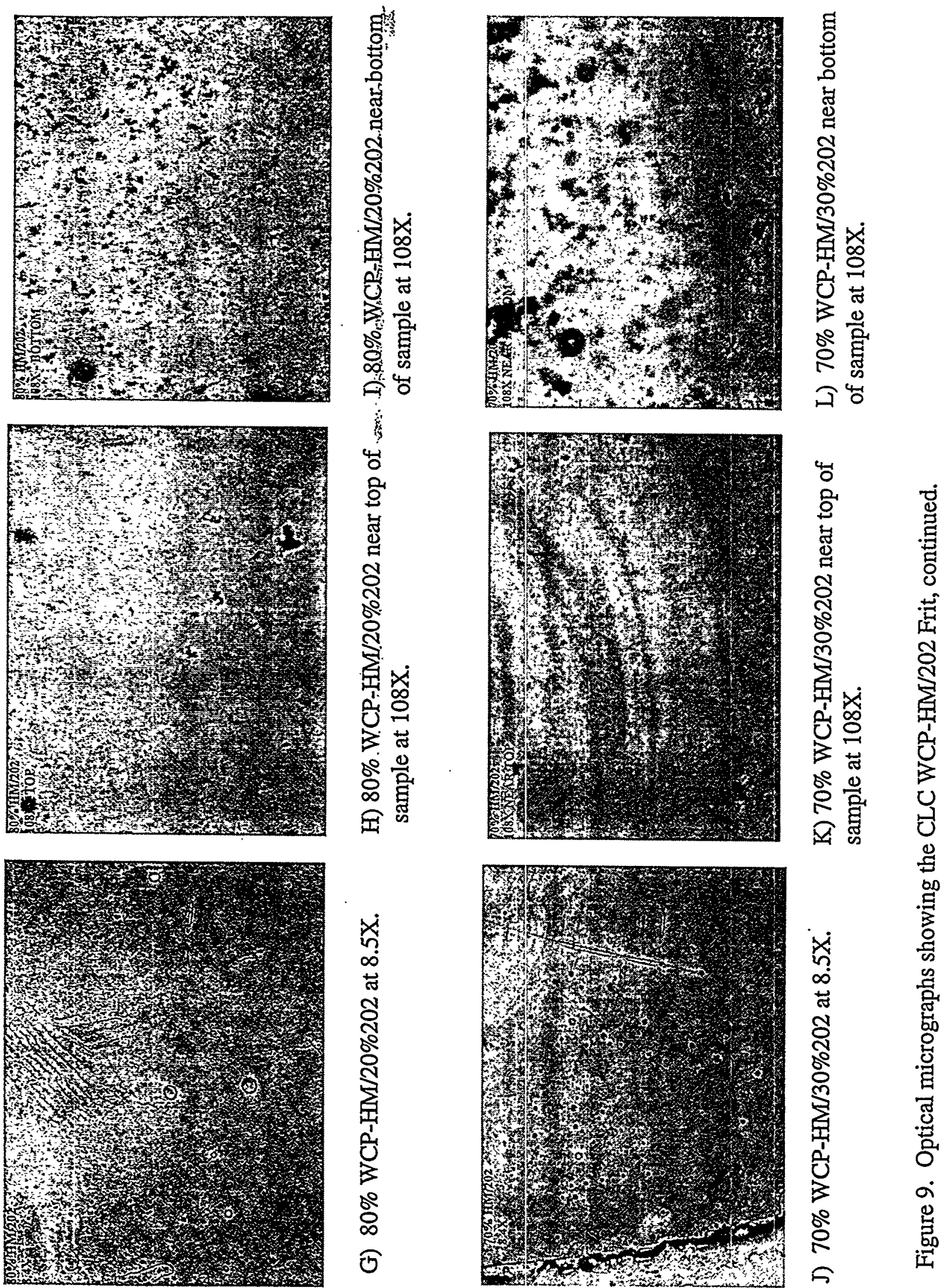


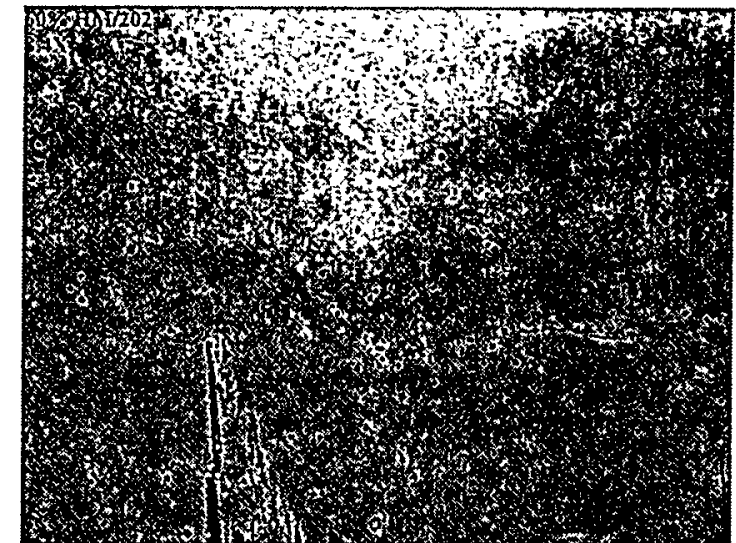

M) $60 \% \mathrm{WCP}-\mathrm{FM} / 40 \% 202$ at $8.5 \mathrm{X}$.

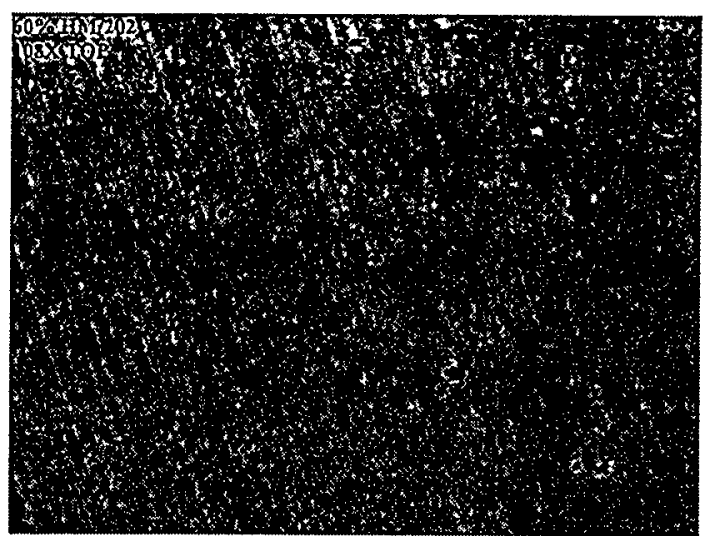

N) $60 \%$ WCP-HM/40\%202 near top of sample at $108 \mathrm{X}$.

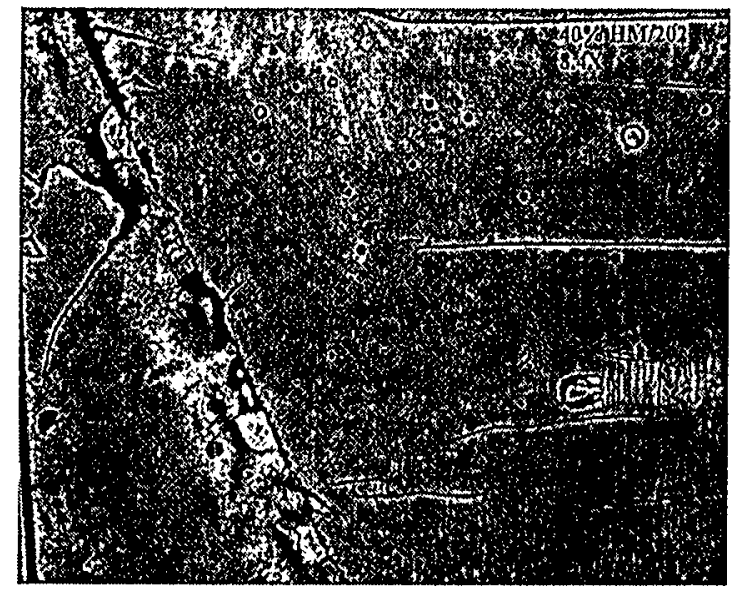

P) $40 \% \mathrm{WCP}-\mathrm{HM} / 60 \% 202$ at $8.5 \mathrm{X}$.

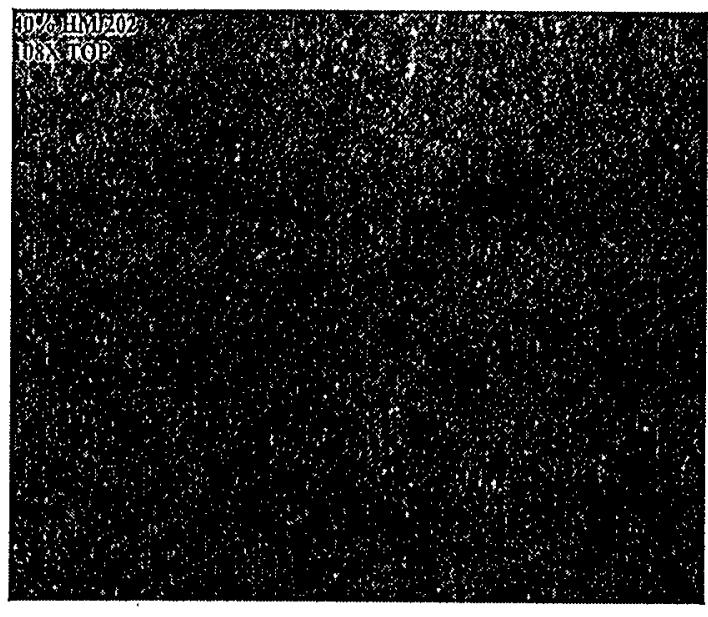

Q) $40 \%$ WCP-HM/60\%202 near top of sample at $108 \mathrm{X}$.

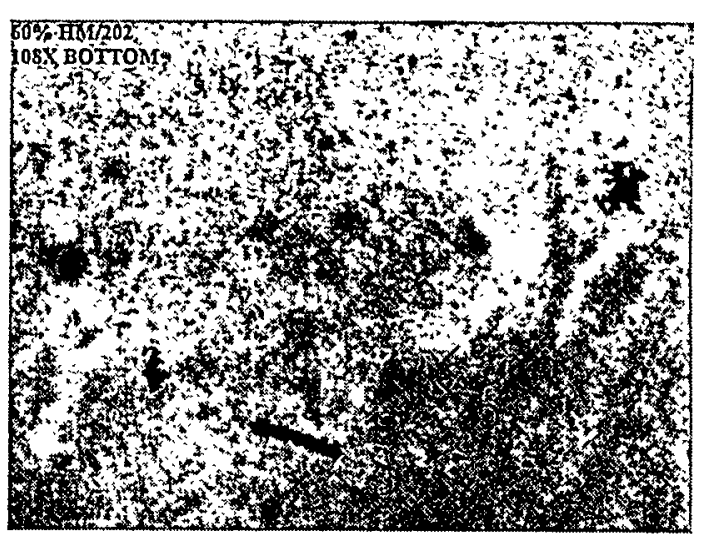

0) $60 \%$ WCP-HM/40\%202 near bottom of sample at $108 \mathrm{X}$.

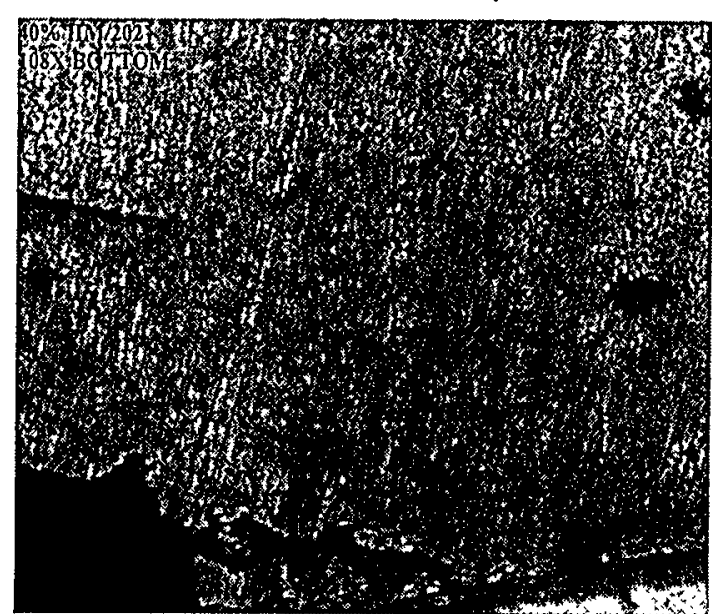

R) $40 \%$ WCP-HM $/ 60 \% 202$ near bottom of sample at $108 \mathrm{X}$.

Figure 9. Optical micrographs showing the CLC WCP-HM/202 Frit, continued. 
WSRC-TR-2000-00010, Revision 0
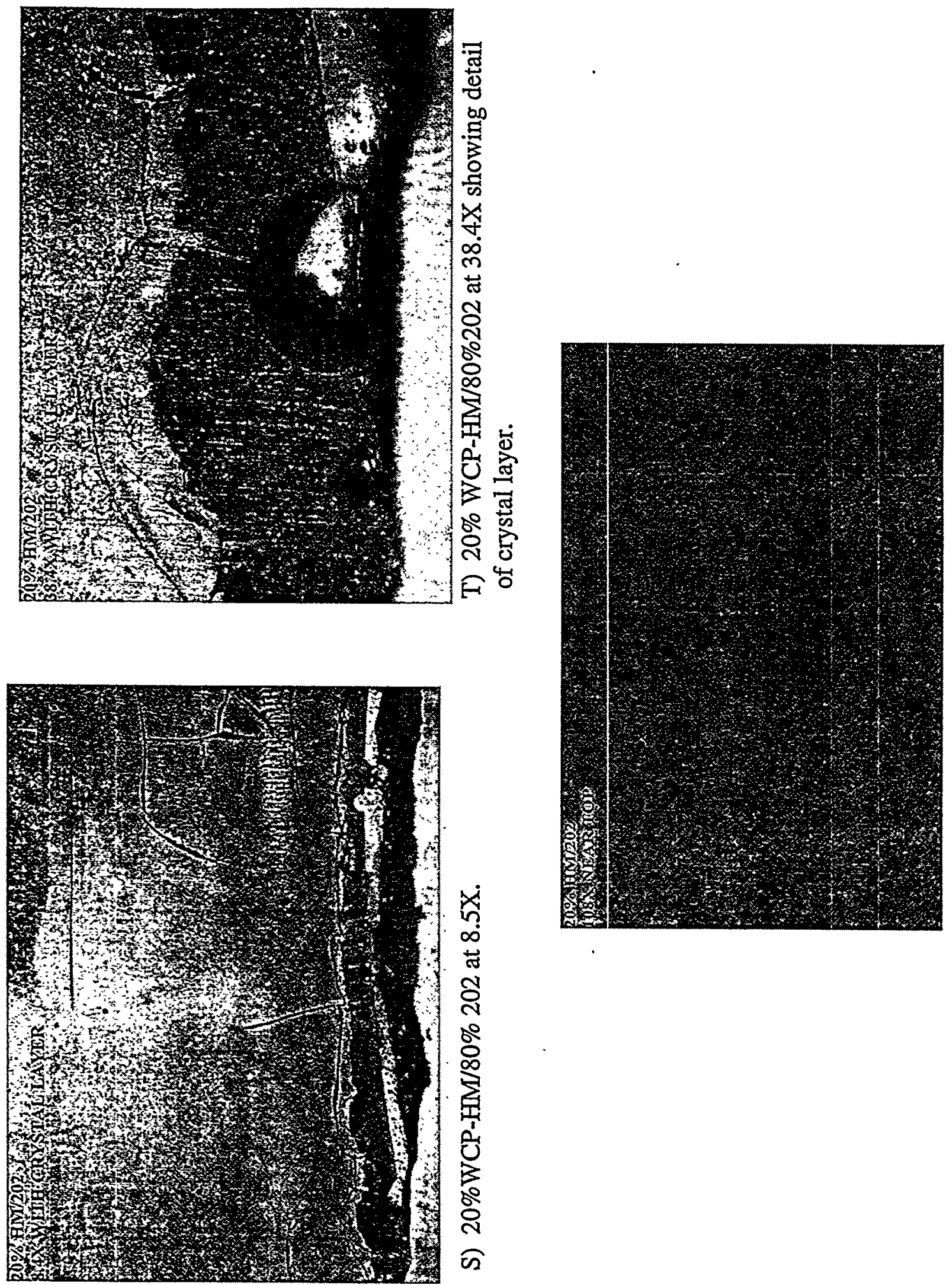

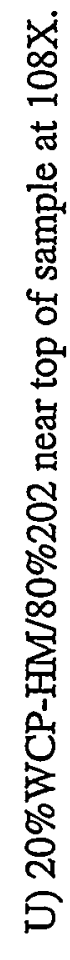

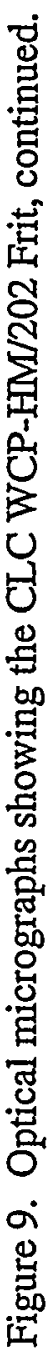




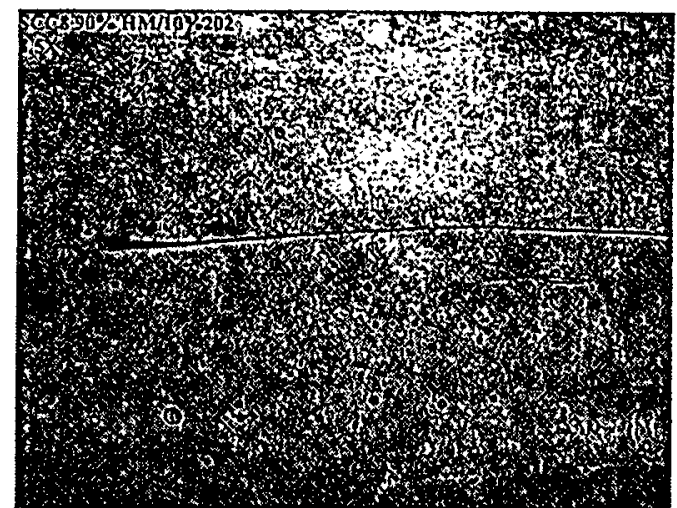

A) $90 \%$ WCP-HM/ $10 \% 202$ at $8.4 \mathrm{X}$.

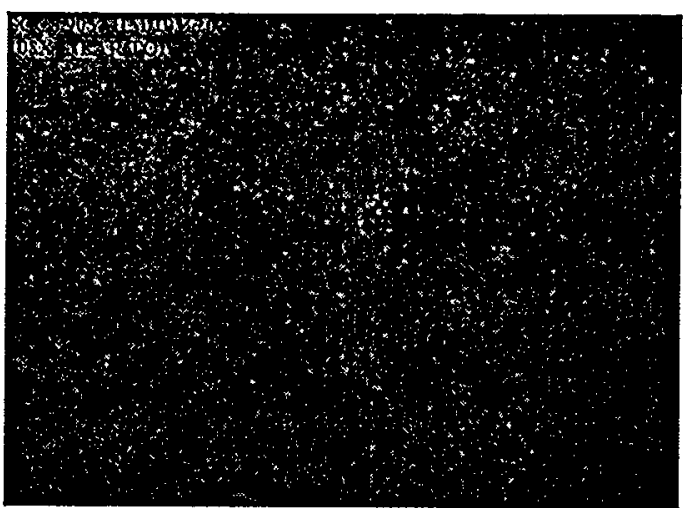

B) $90 \%$ WCP-HM/10\% 202 near top at $108 \mathrm{X}$

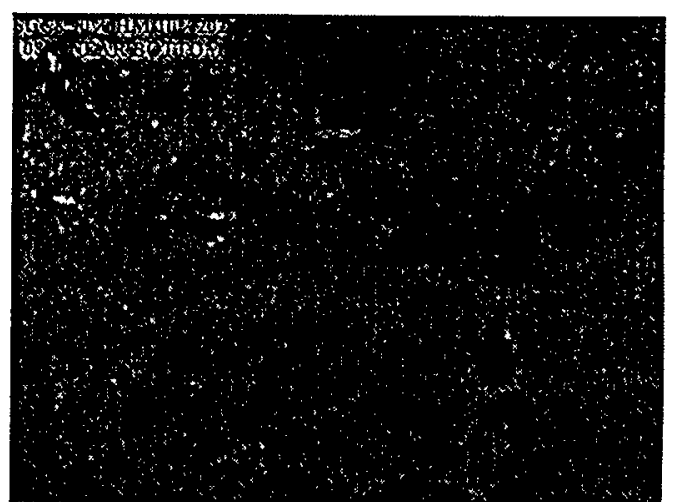

C) $90 \%$ WCP-HM/10\% 202 near bottom.

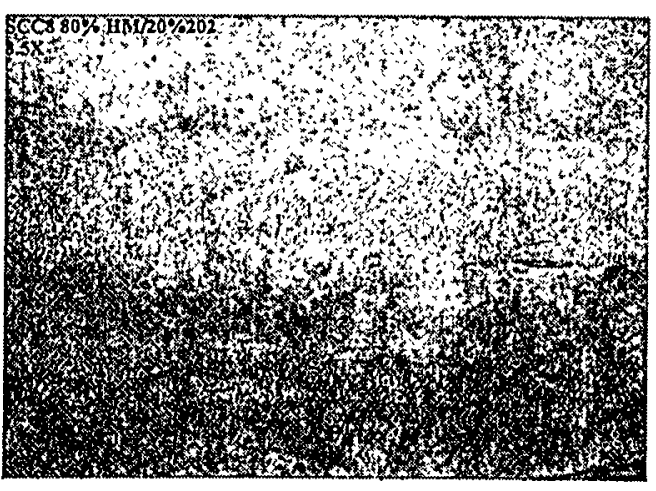

D) $80 \%$ WCP-HM $/ 20 \% 202$ at $8.4 \mathrm{X}$.

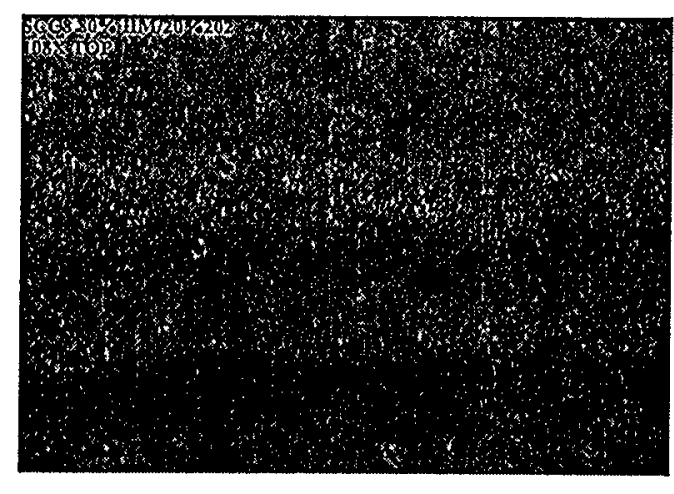

E) $80 \%$ WCP-HM/20\% 202 near top at $108 \mathrm{X}$

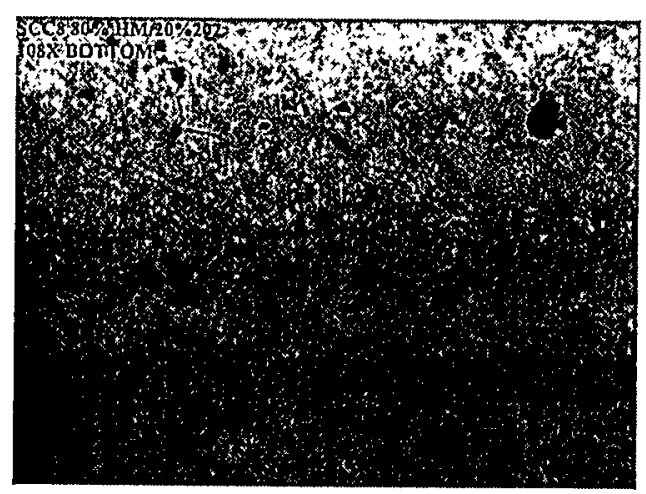

F) $80 \%$ WCP-HM/20\% 202 near bottom.

Figure 10. Optical micrographs showing the WCP-HM/Frit 202 glasses subjected to DWPF simulated surface canister cooling . 
WSRC-TR-2000-00010, Revision 0
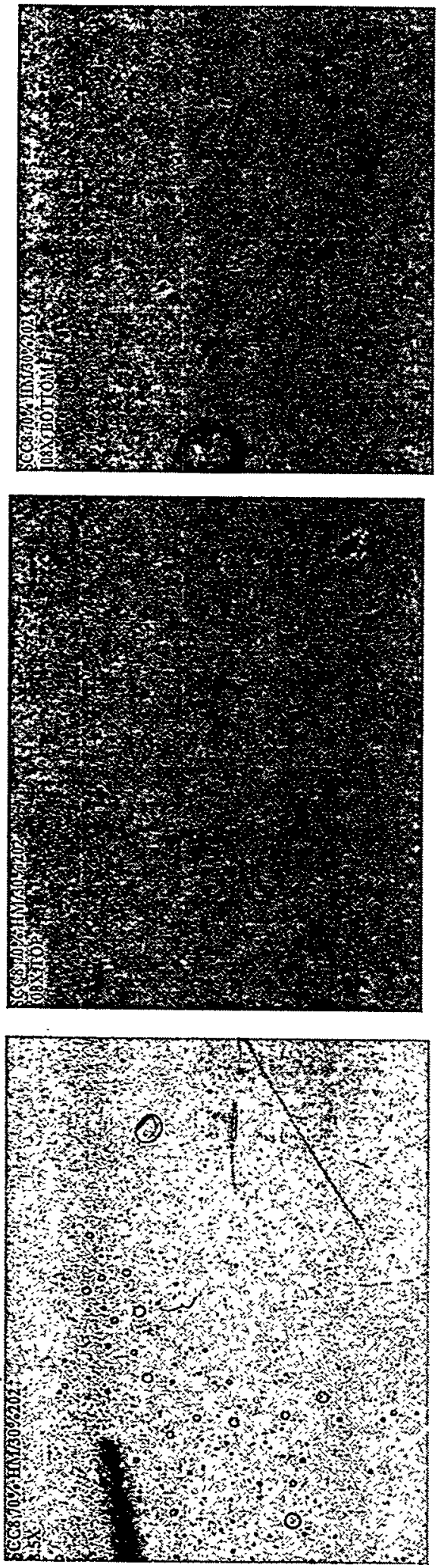
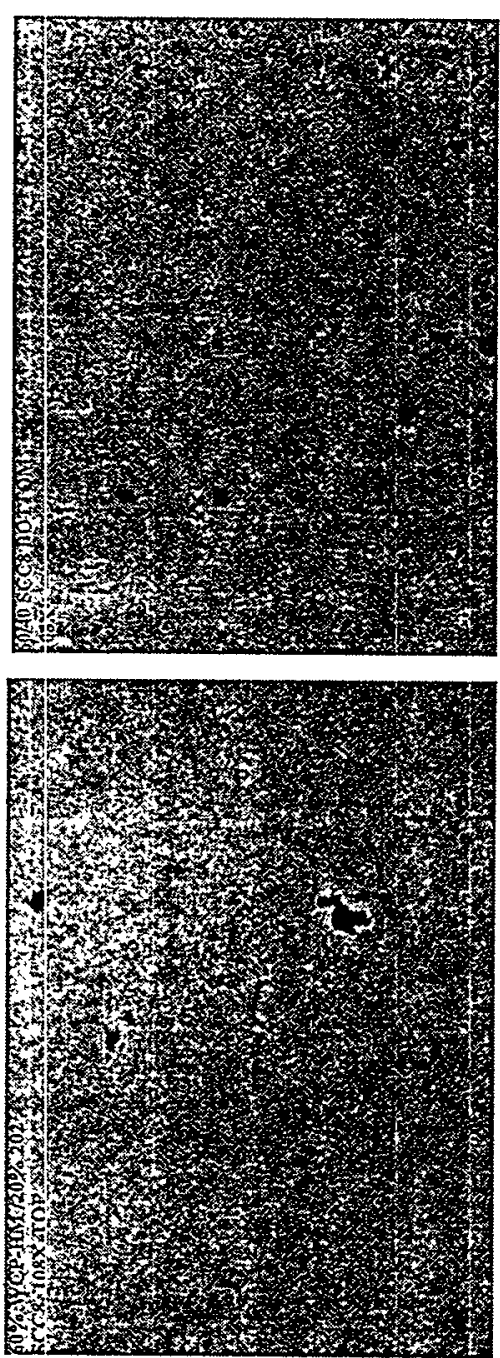

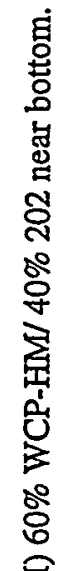
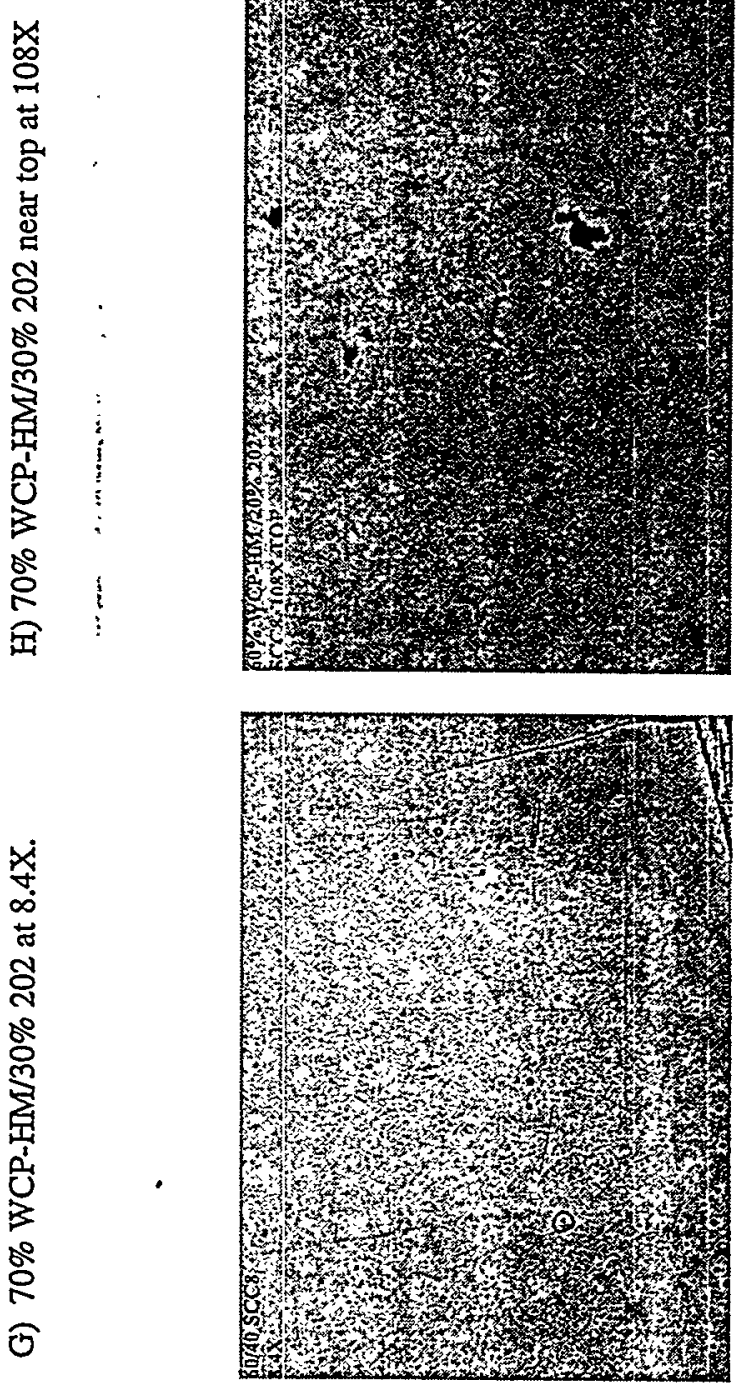

'0త

$\stackrel{0}{乛}$

照

爻

受

ปั

ㅇํㅇ

\&

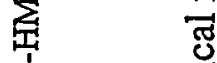

$\bigcup_{1}^{1} \quad$ हैं

今ᄋ

ธิ

总 
WSRC-TR-2000-00010, Revision 0
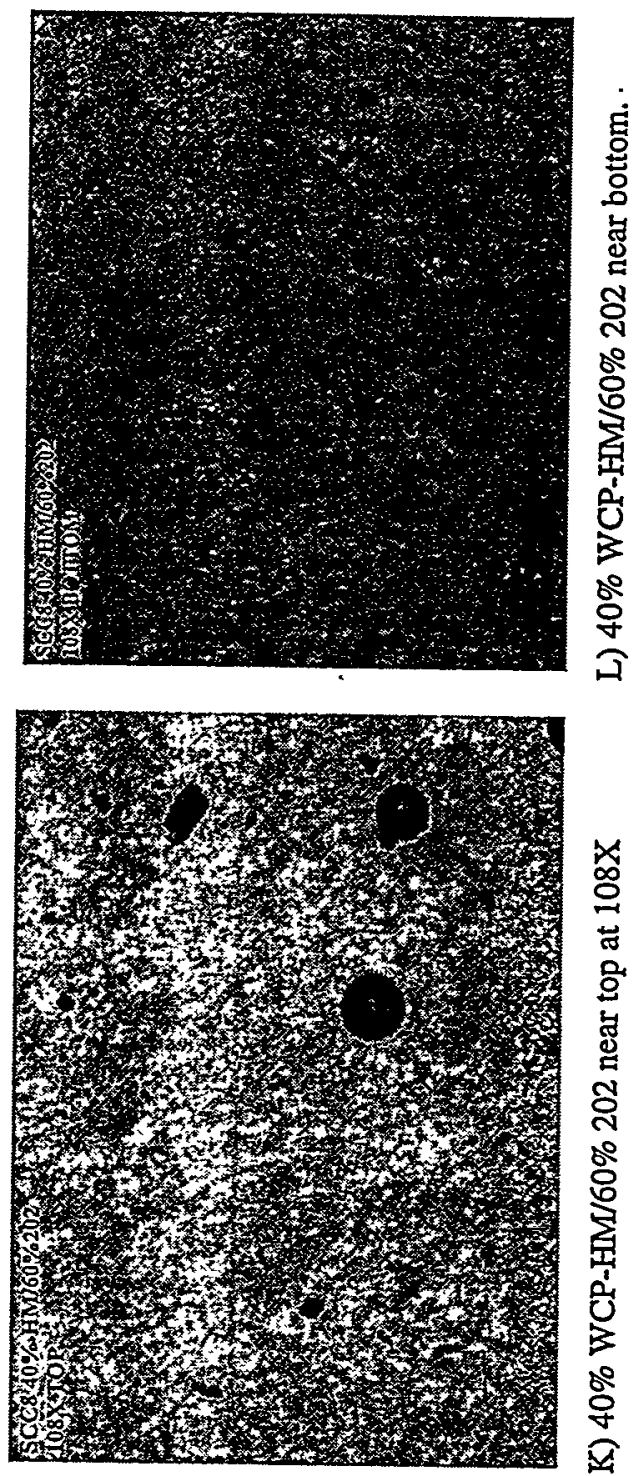

苂

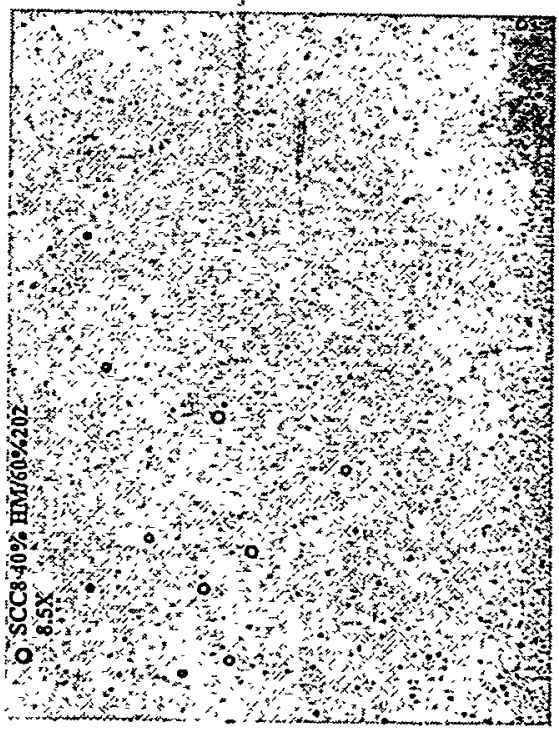

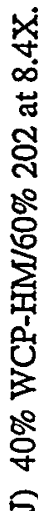

ઠิ

空

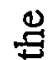

弯

$\stackrel{\dot{9}}{9}$

总 

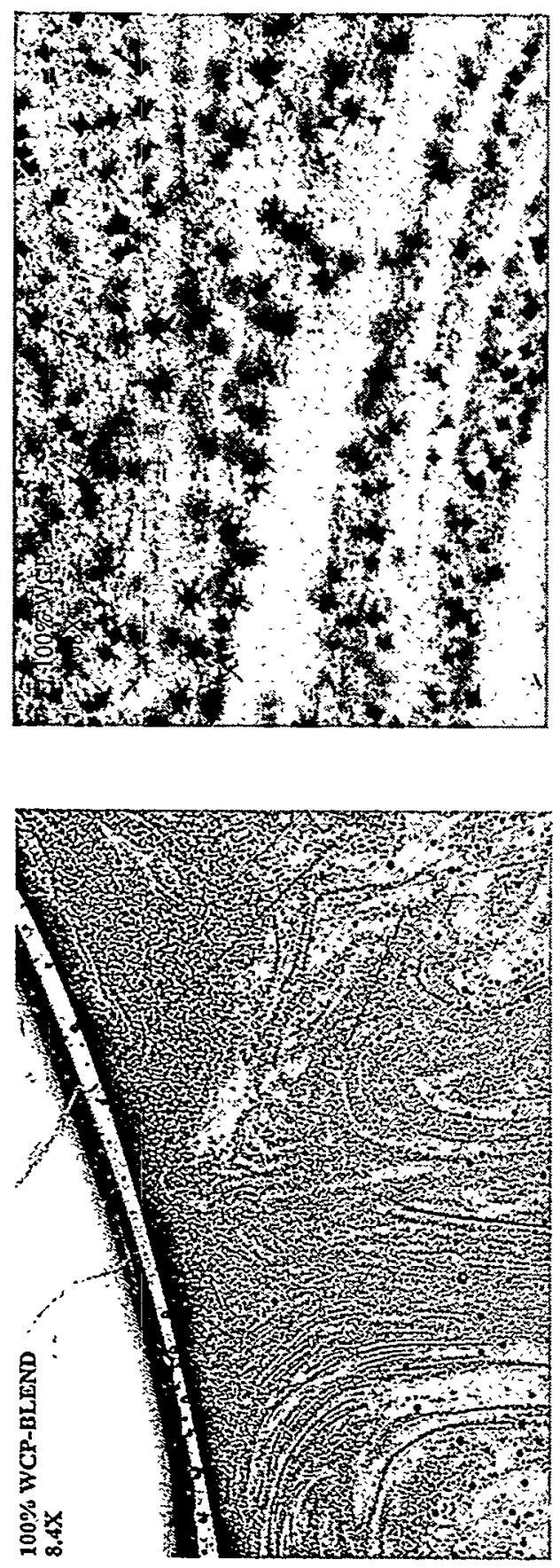

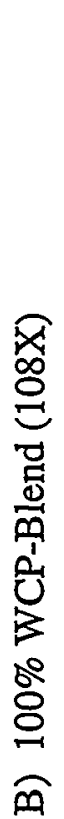

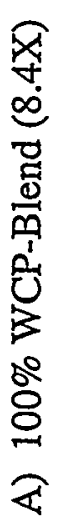

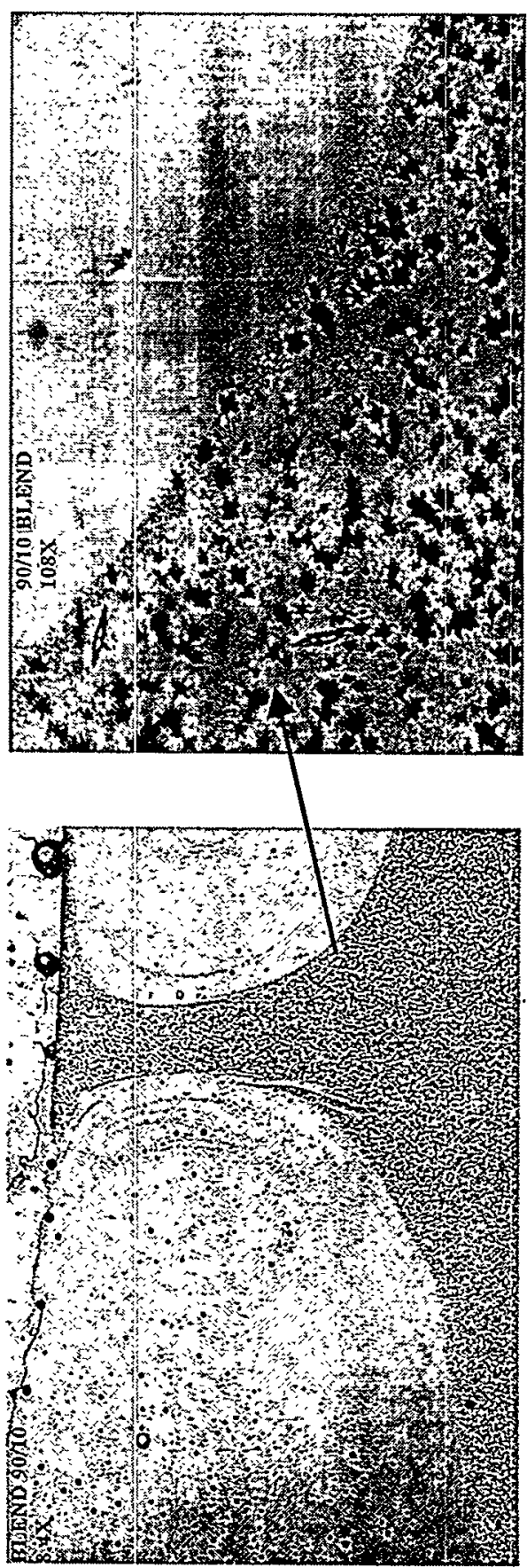

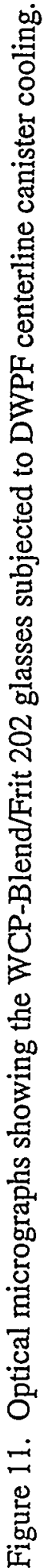




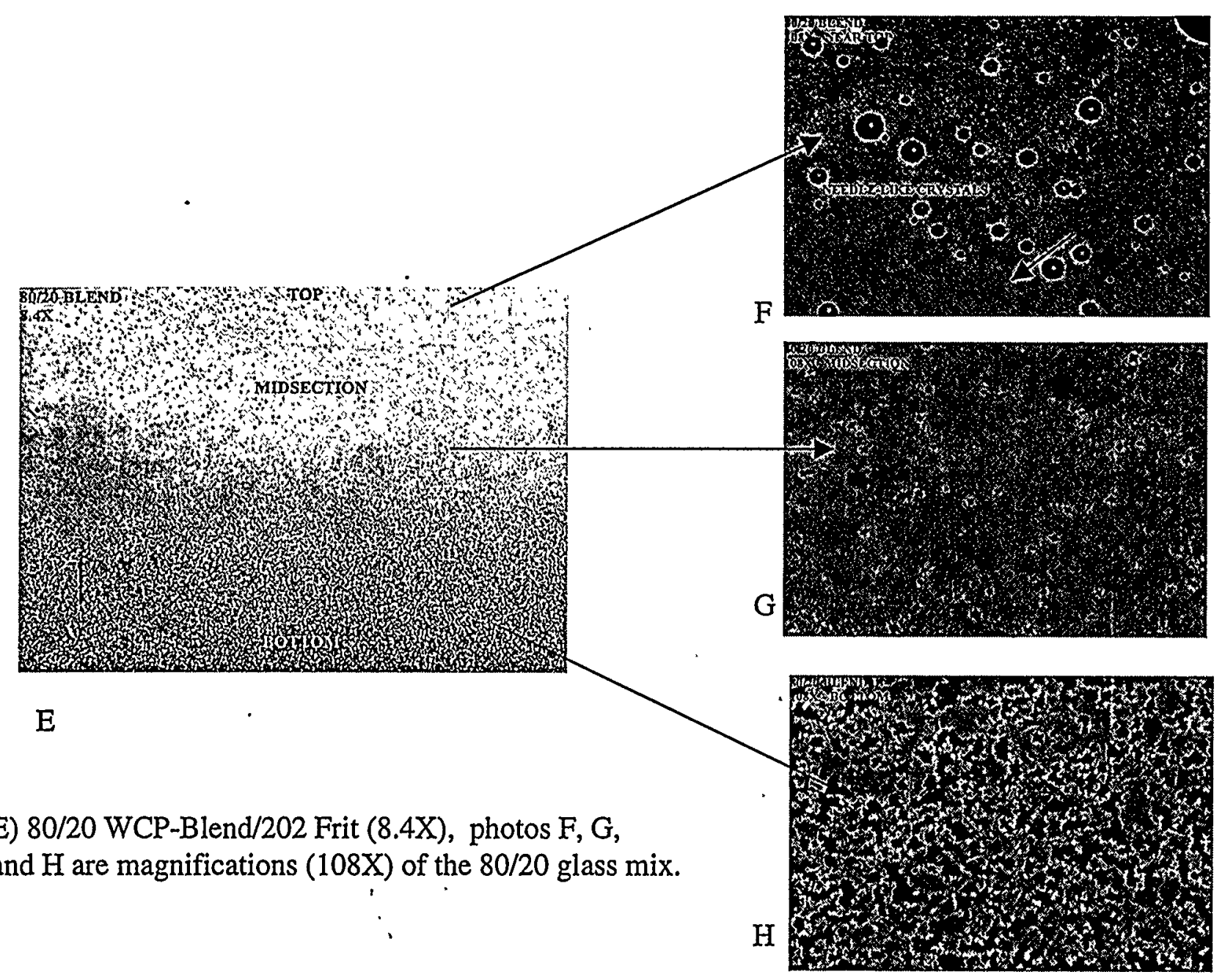

Figure 11. Optical micrographs showing the CLC WCP-Blend/Frit 202 glasses, continued. 
WSRC-TR-2000-00010, Revision 0
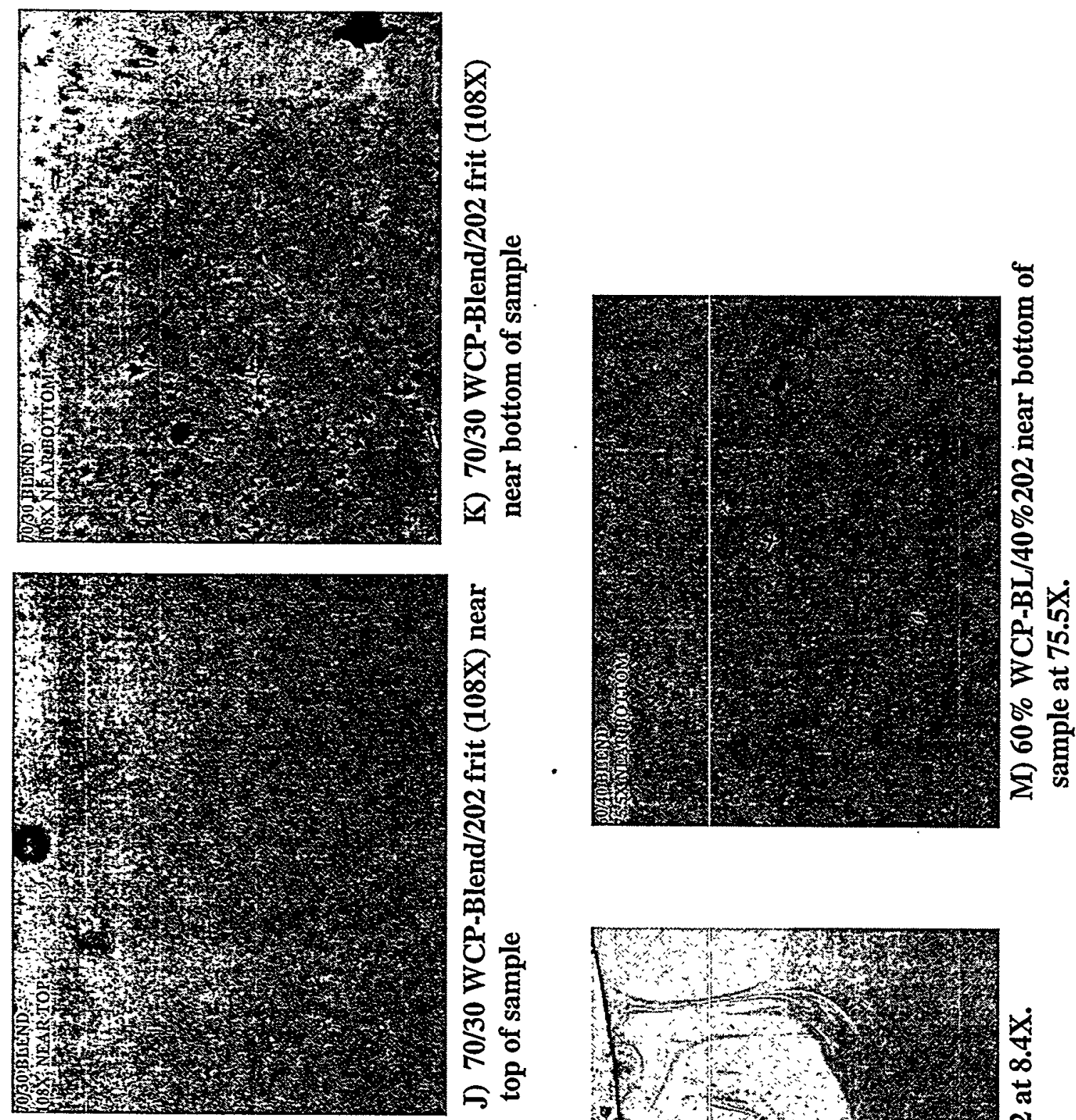

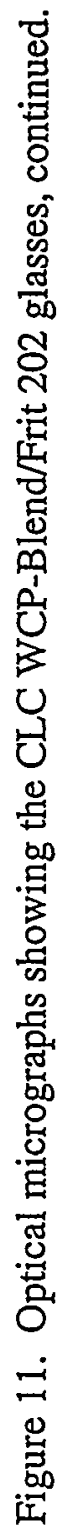
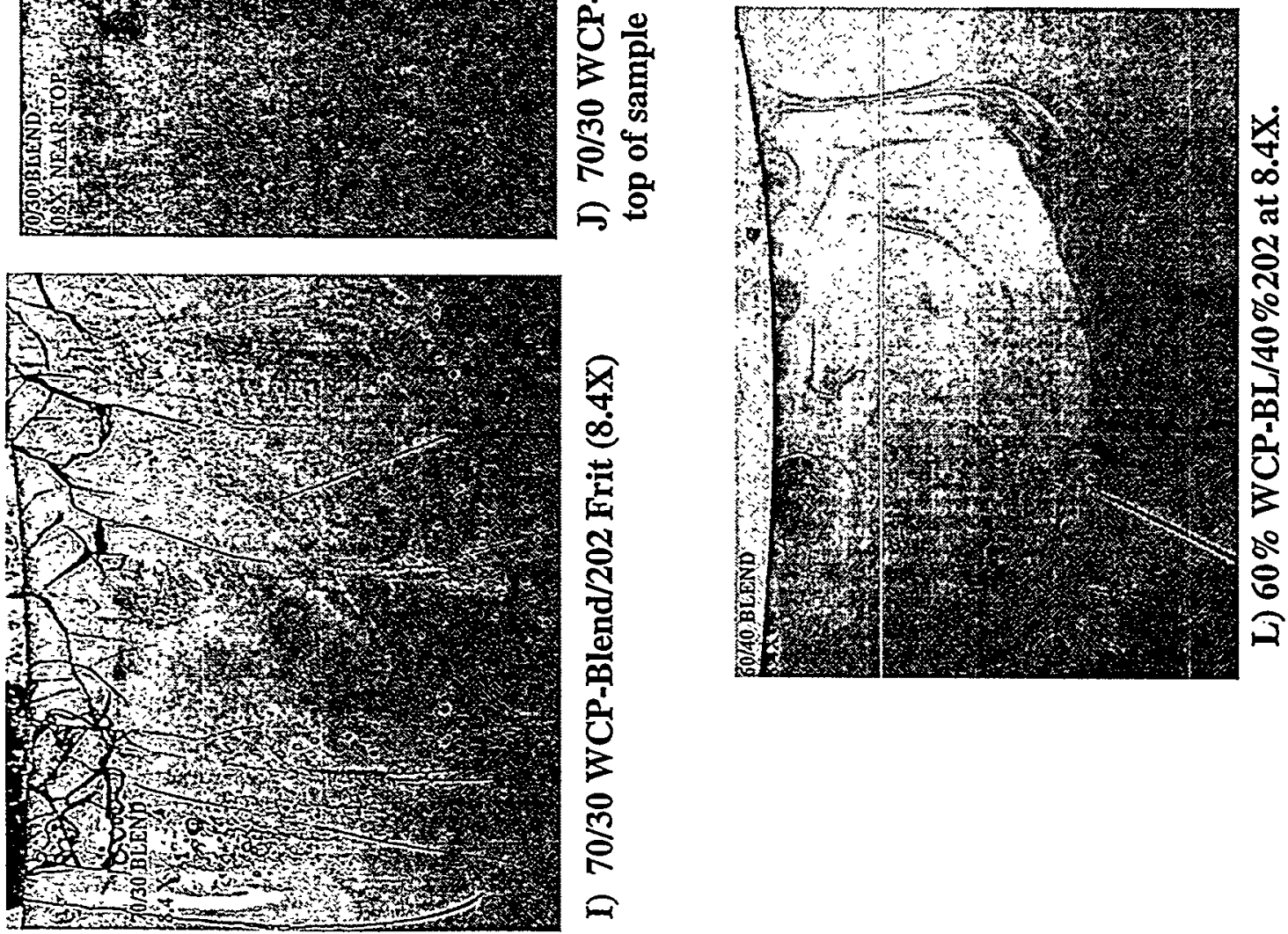


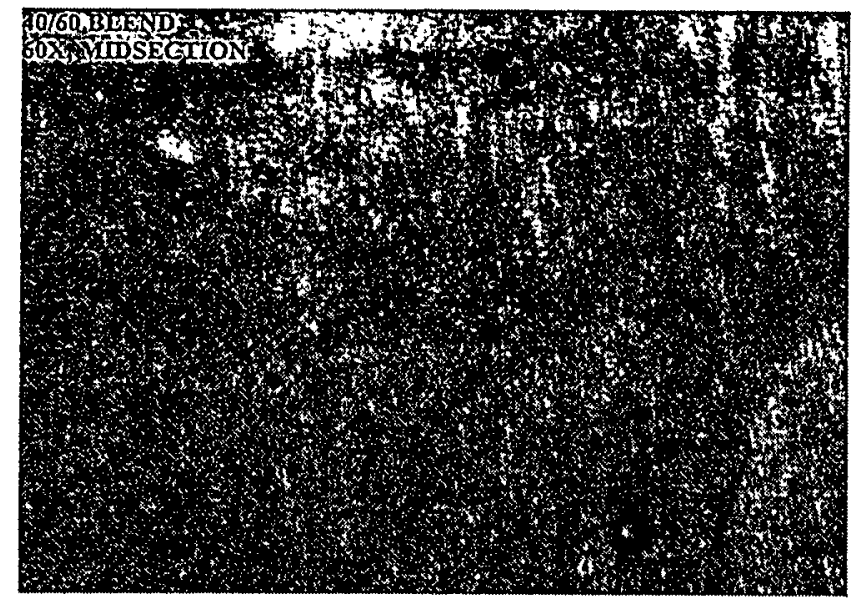

N) 40/60 WCP-Blend/202 Frit (60X)

N

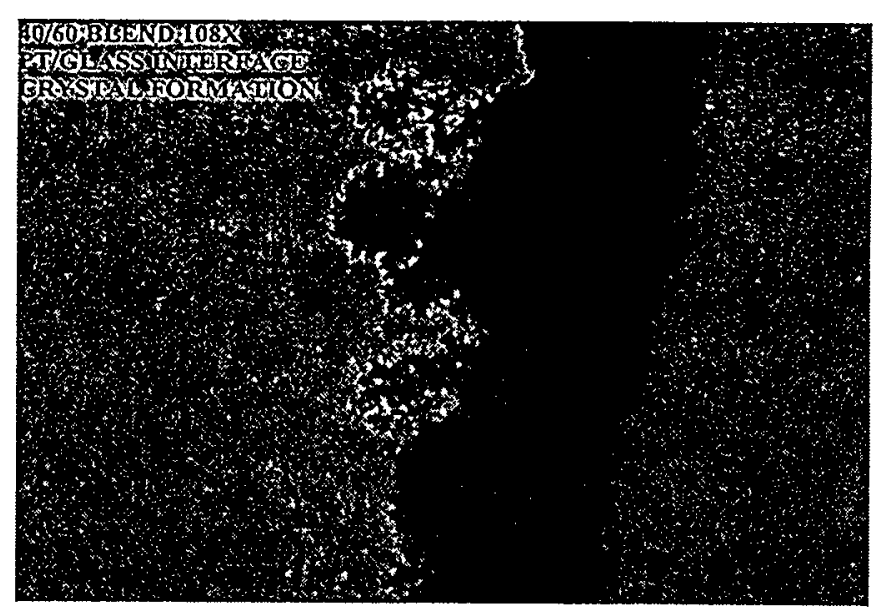

O) 40/60 WCP-Blend/202 Frit at Pt/sample interface (108X). Beginning development of thin crystalline layer at the Pt/glass interface.

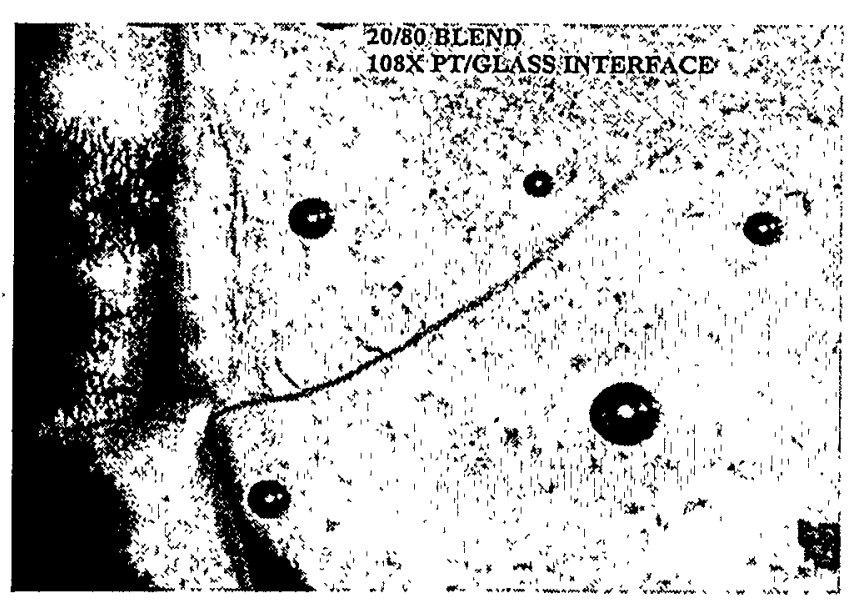

P) 20/80 WCP-Blend/202 Frit (108X) crystalline development at $\mathrm{Pt} /$ sample interface.

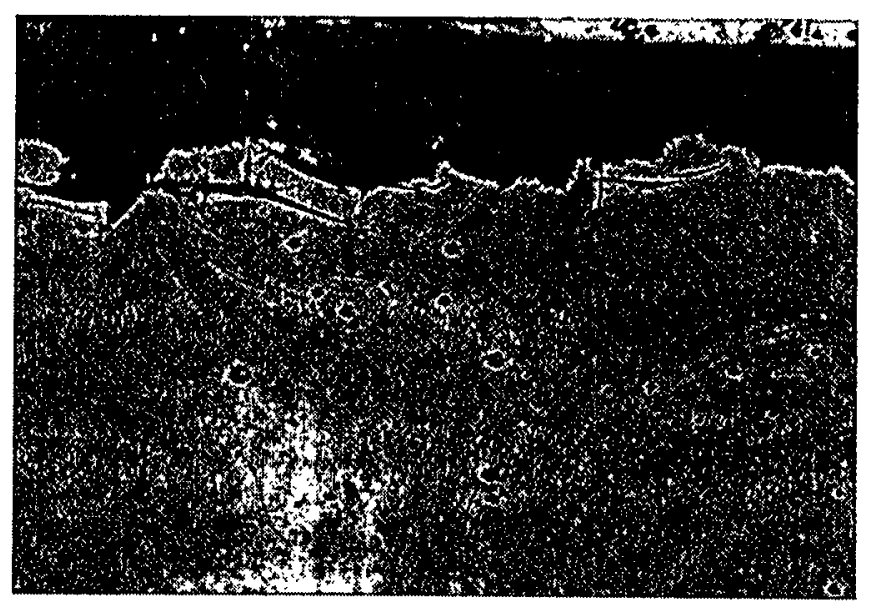

Q) 20/80 WCP-Blend/202 Frit (38.4X) showing crystalline development at $\mathrm{Pt} /$ sample interface.

Figure 11. Optical micrographs showing the CLC WCP-Blend/Frit 202 glasses, continued. 
WSRC-TR-2000-00010, Revision 0
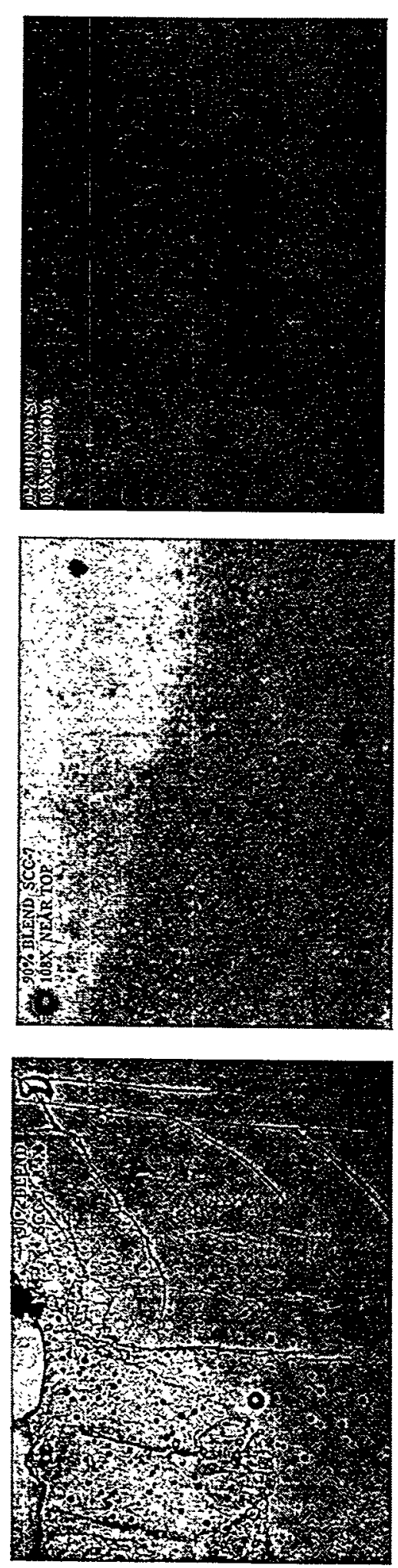
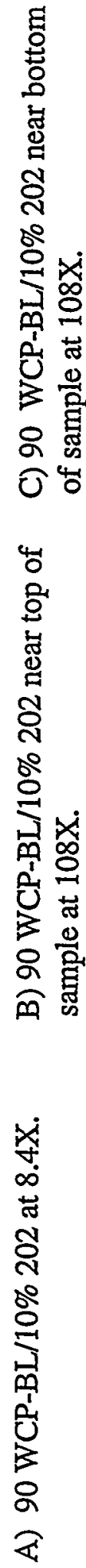
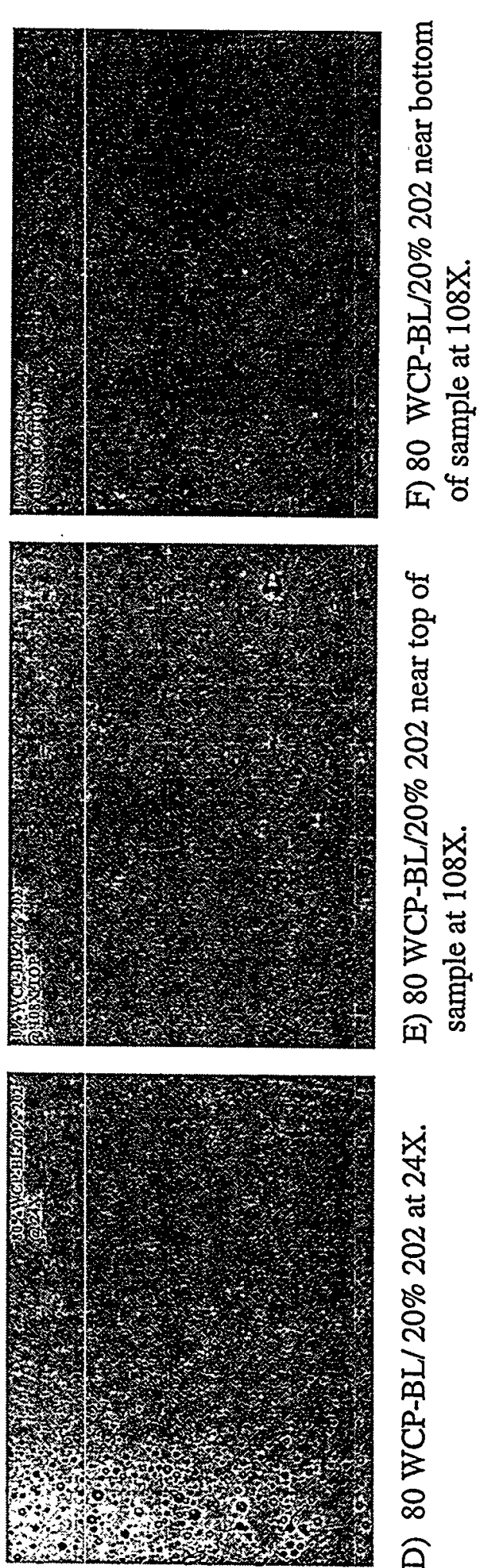


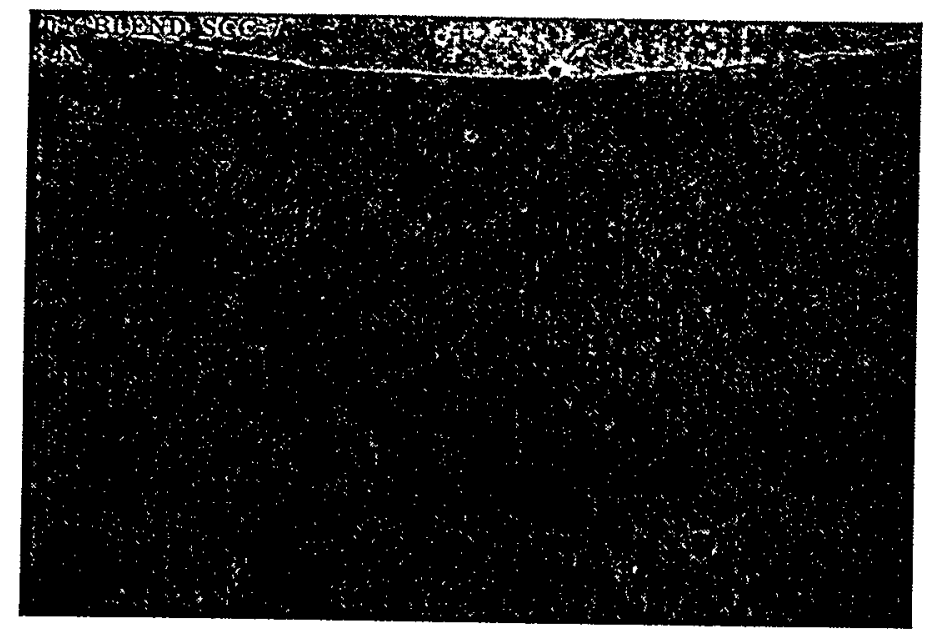

G) $70 \%$ WCP-BL/30\%202 at $8.4 \mathrm{X}$.

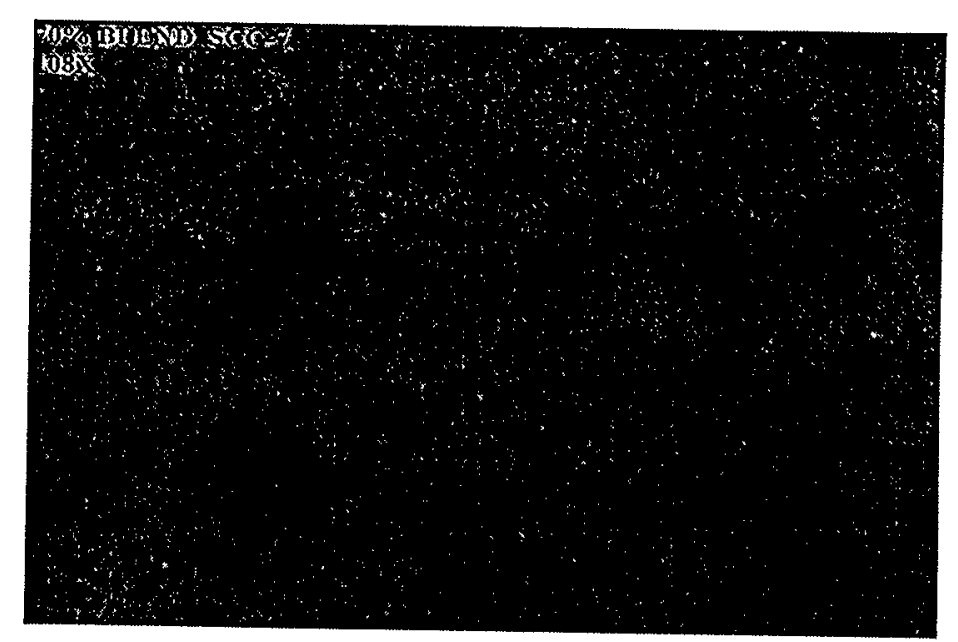

H) $70 \% \mathrm{WCP}-\mathrm{BL} / 30 \% 202$ at $108 \mathrm{X}$.

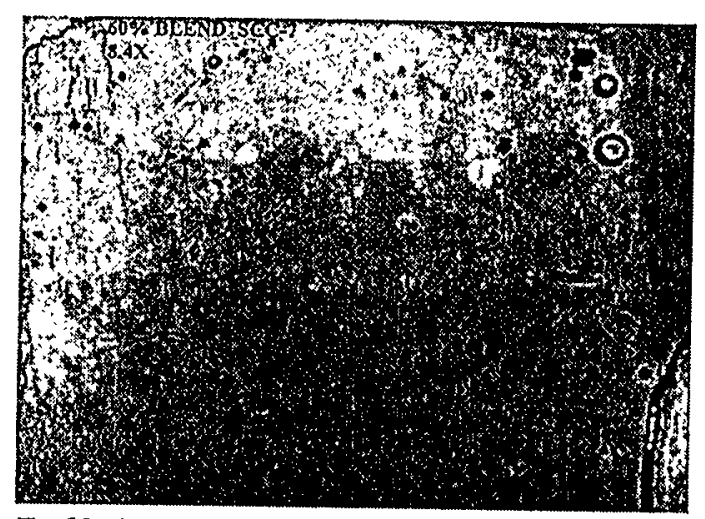

D) $60 \% \mathrm{WCP}-\mathrm{BL} / 40 \% 202$ at $8.4 \mathrm{X}$. sample at 108X.

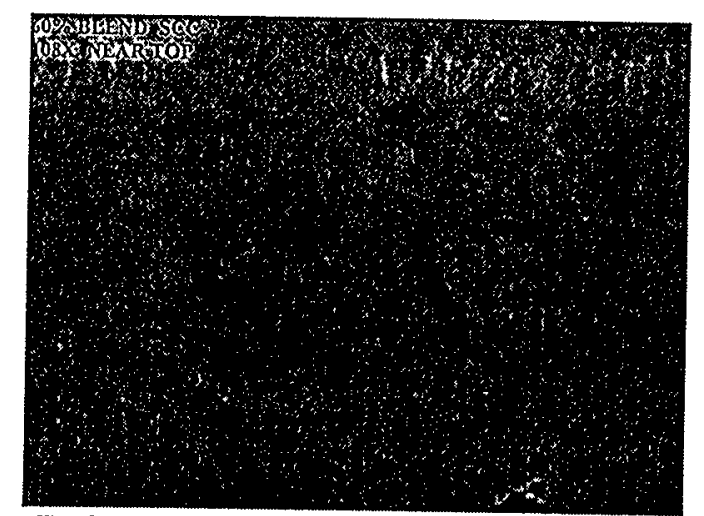

J) $60 \%$ WCP-BL/40\% 202 near top of bottom of sample at 108X.

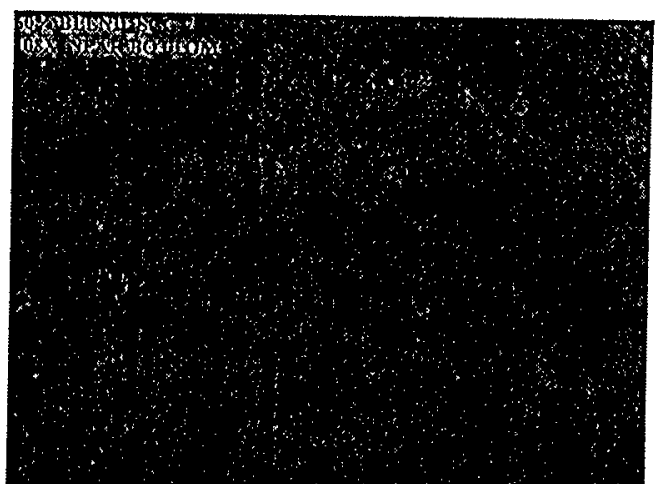

K) $60 \% W C P-B L / 40 \% 202$ near

Figure 12. Optical micrographs showing the SCC WCP-Blend/Frit 202 glasses, continued. 
WSRC-TR-2000-00010, Revision 0
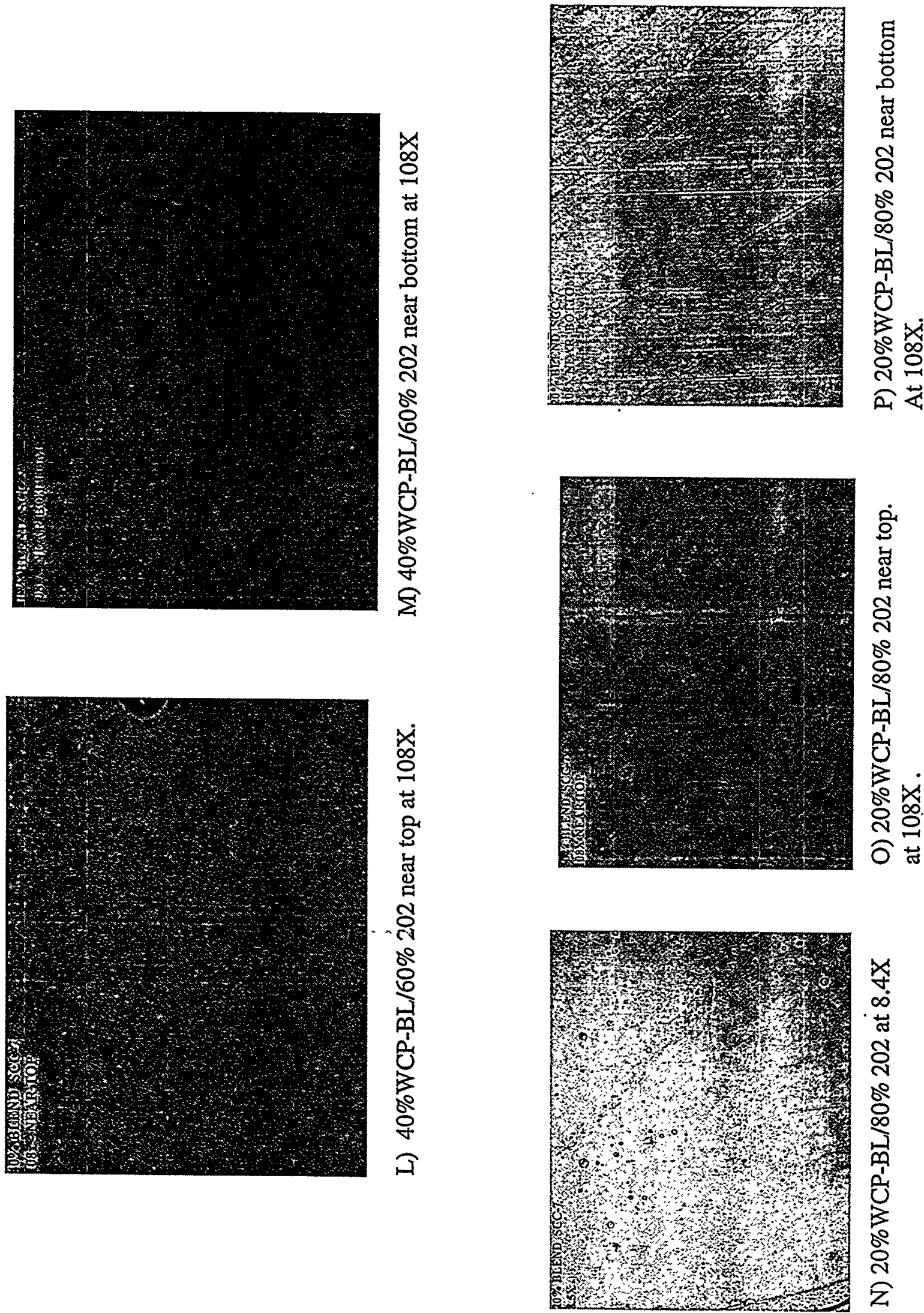

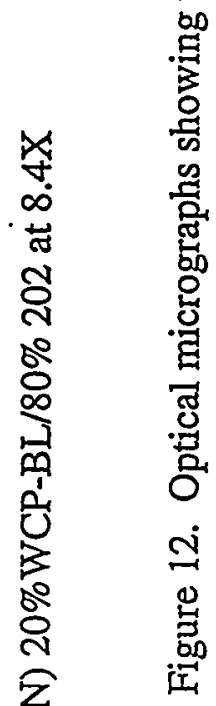


WSRC-TR-2000-00010, Revision 0

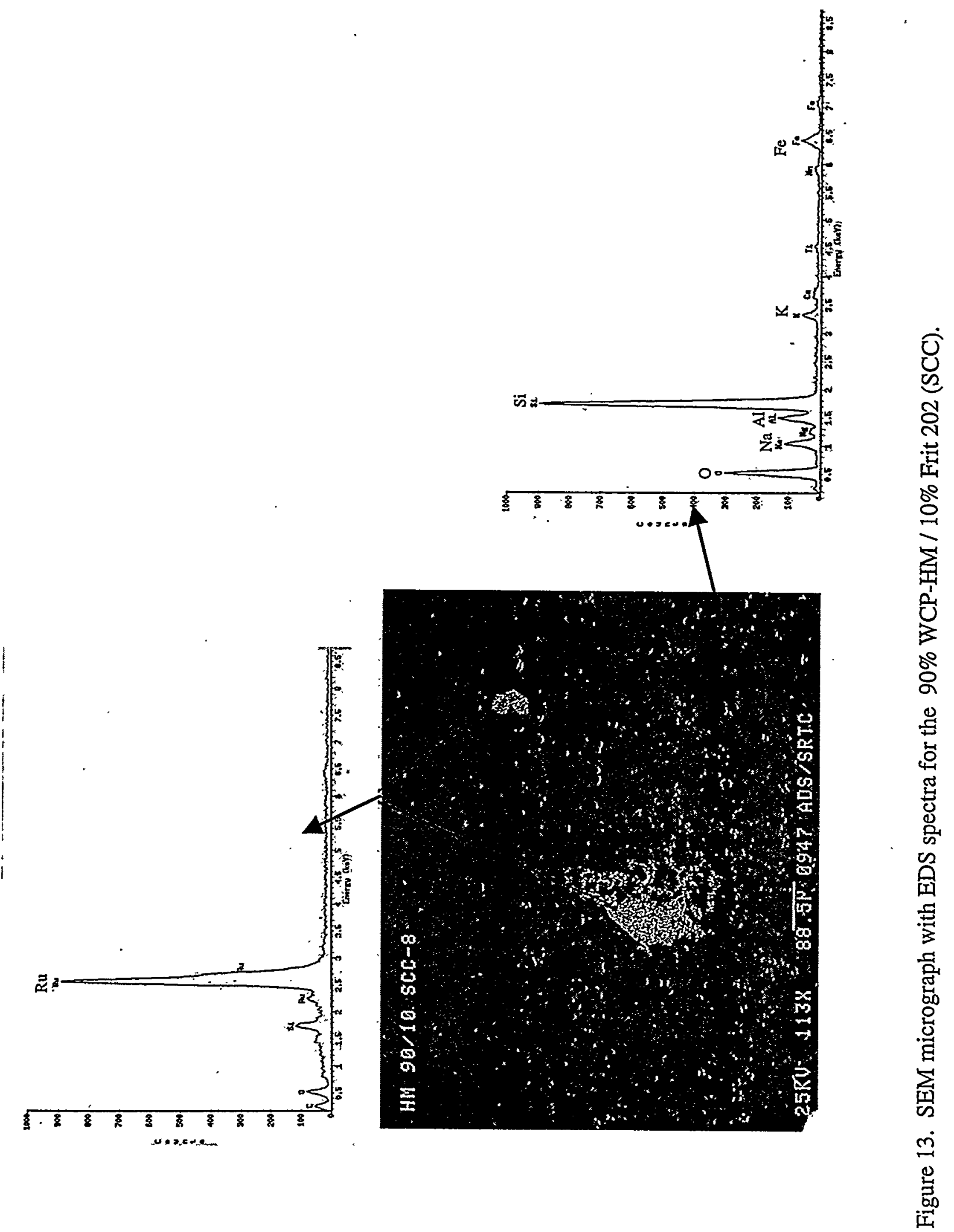


WSRC-TR-2000-00010, Revision 0

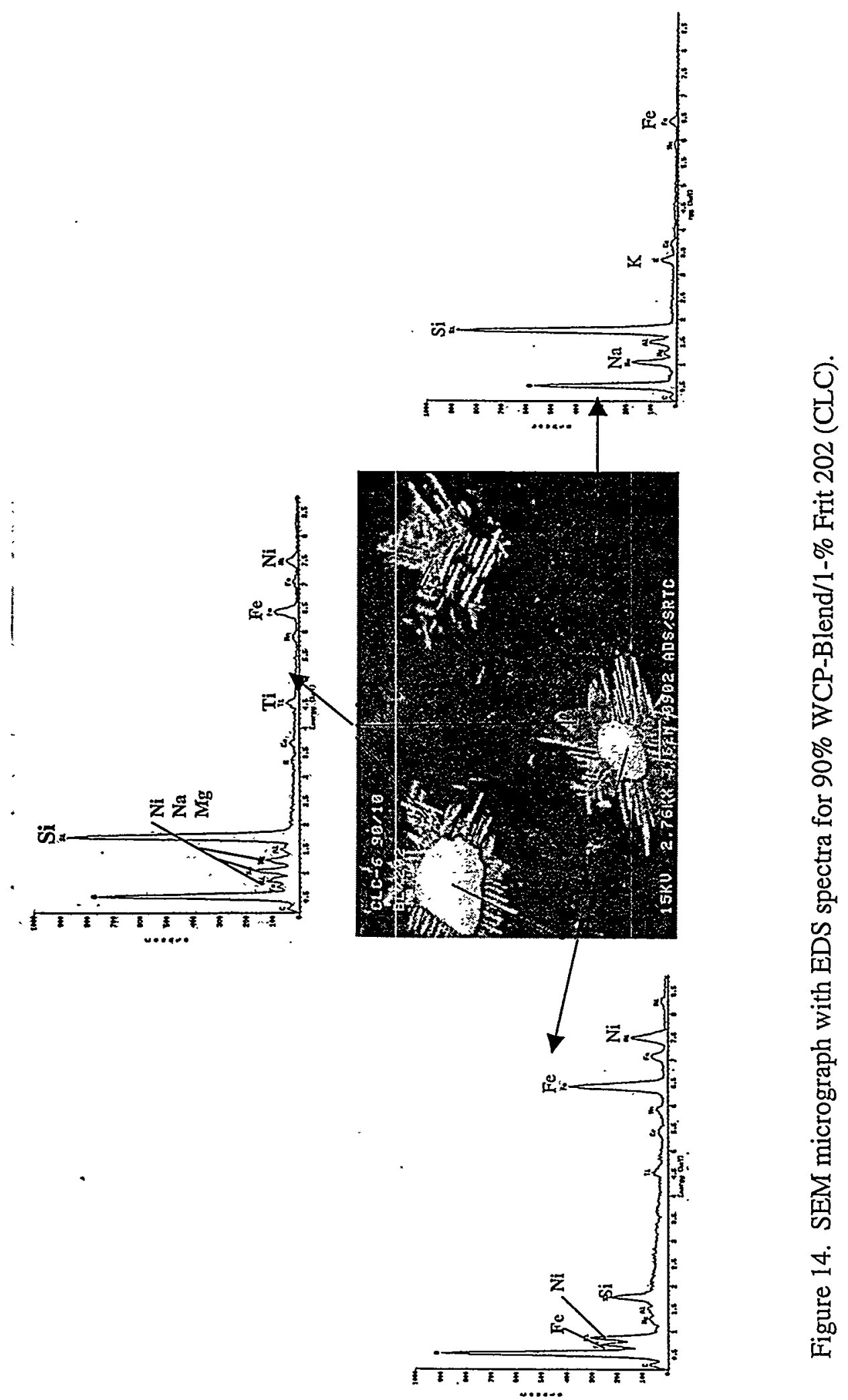


WSRC-TR-2000-00010, Revision 0

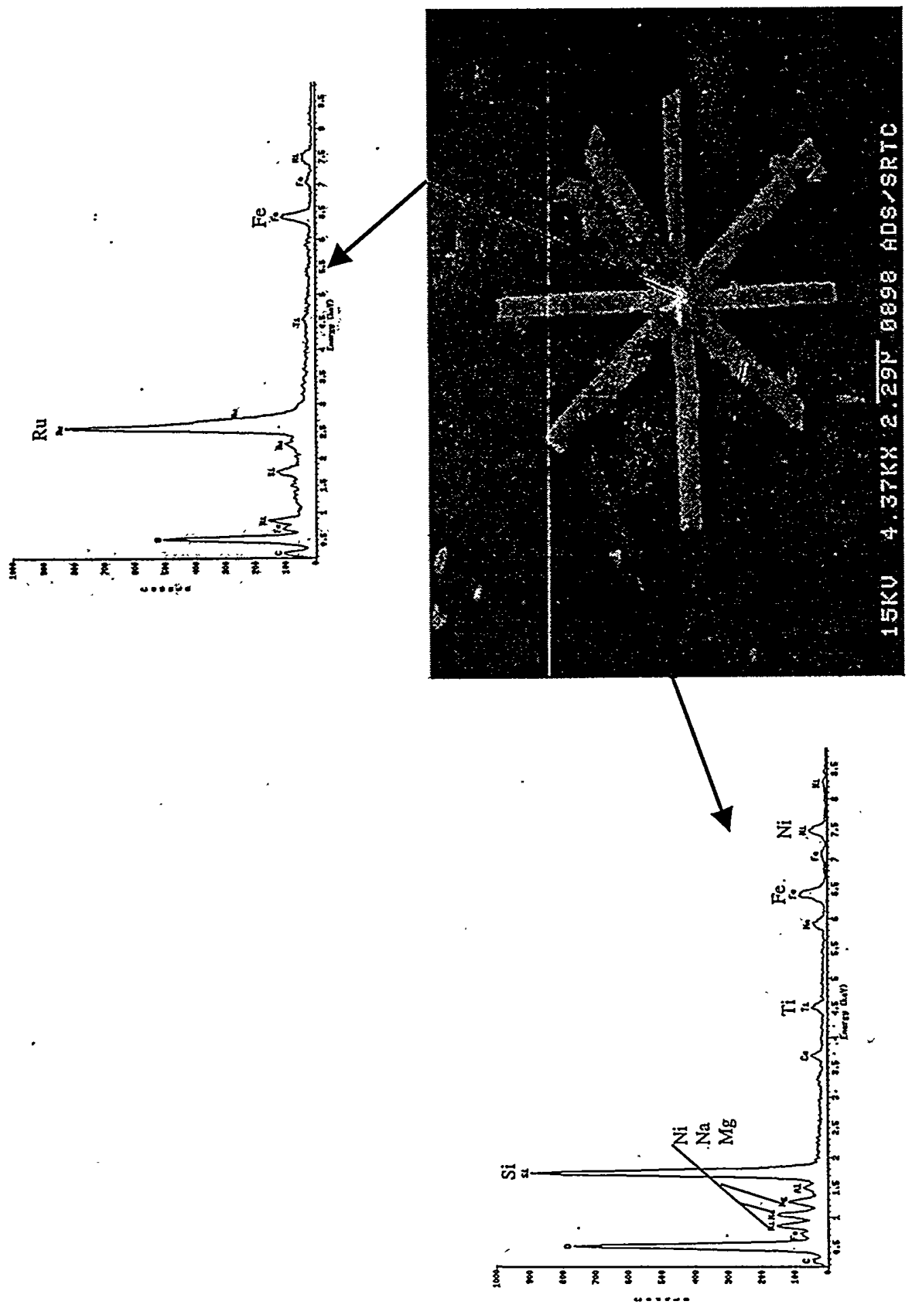

它

ชั

吉

80

马्ב

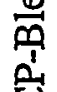

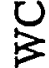

웅

$\stackrel{0}{ \pm}$

苍

要

峁

兊

녹

要

.0․ㅇ․․

$\sum_{\text {空 }}^{5}$

$\dot{n}$

号

i昰 
separation nose, but would not cross the SCC curve. The proposed TTT diagram that agrees with this pathway is TTT " $F$ " shown in Figure 2.

It was speculated that the macroscopic phase separation (layering) observed may have been due to insufficient time allowed for homogenization of the two glasses or perhaps incomplete mixing prior to melting. To determine if either of these were the cause of the observed phenomena, two additional experiments were conducted. The first involved taking selected specimens from the WCP-Purex/202 CLC and SCC runs, crushing the glasses and re-melting them. For the centerline cooled 80/20 glass the same layering effect was observed and for the $20 / 80 \mathrm{mix}$ an even greater degree of crystallization was observed (see Figure 16). The SCC glasses (60/40, 40/60 and 20/80) were crushed and re-melted, but after holding at $1150^{\circ} \mathrm{C}$ for 4 hours, the molten glass was poured into graphite crucibles and then placed in a second furnace for the remainder of the SCC run. The results are shown in Figure 17. While the distinct top/bottom layering was not evident, a ring or swirl pattern with light and dark glass was observed, somewhat similar to the pan-quenched glasses. As with the previous SCC glasses, crystals were not detected. The second experiment involved holding selected WCP-Purex/202 (95/5, 90/10, 85/15, $80 / 20,75 / 25$ and $70 / 30$ ) compositions at $1150^{\circ} \mathrm{C}$ for 5 days. The specimens were removed from the furnace and allowed to air cool in the crucibles. During sectioning operations all the samples fractured as internal stresses were relieved. Therefore, it was decided that the glasses should be re-melted, held at $1150^{\circ} \mathrm{C}$ for 3 days, followed by an annealing step $\left(450^{\circ} \mathrm{C}\right.$ for 1 hour) and allowed to furnace cool. The glasses will be examined microscopically and subjected to durability testing. Results from these experiments will be provided in a future report.

\subsection{Compositional Analyses and Density Measurements}

Results of the compositional analyses of the glass specimens prior to PCT are shown in Table 3. Density measurements are shown in Table 4. Density measurements showed that the densities of the two layers (top and bottom) were slightly different: phase separation is the separation of two phases with different compositions and different densities. As would be expected, the denser glass composition settled to the bottom of the crucible. An analysis by oxide composition as a function of excess frit and cooling schedule (SCC or CLC) indicated that in general, the transition metal oxides along with, iron, aluminum, titanium, copper, calcium, barium, and some sodium, potassium and boron oxides were found in larger concentrations in the denser phase. Lithium appeared to be, for the most part, evenly distributed between the lighter and the denser phases. Silica and magnesium oxide were more concentrated in the lighter phase. These trends are shown graphically in Figures 18-24. Comparing the centerline cooled sample compositions (tops vs. bottoms) vs. the surface cooled sample compositions there are larger compositional differences between the separated phases in the more rapid canister surface cooled samples than in the canister centerline cooled samples. This is consistent with the most recent findings of Tomozawa ${ }^{21}$ and unpublished results by Peeler that a rapidly cooled specimen can have a phase-separated structure that can disappear upon low-temperature annealing. This also implies that the DWPF PSD is conservative in that it avoids glass compositions that have a tendency to phase separate at the melt temperature which have the potential to be annealed or rehomogenized as the waste glass canisters cool.

\subsection{Product Consistency Test - PCT}

The results of standardized durability testing on the top and bottom layers of the 80/20 and 20/80 WCP-Purex/202 glasses are summarized graphically in Figure 25. The pan-quenched glasses tested in a previous study ${ }^{20}$ (also mixtures of Purex and 202 glasses) are shown for comparison. As can be seen from the data, three glasses (the crystallized outer portion of the centerline cooled 20/80 mix, the 20/80 and $100 \%$ frit 202 pan-quenched glass) have normalized boron release rates that exceed that of the DWPF Environmental Assessment (EA) glass, and would be classified as unacceptable with respect to durability. In addition, two samples fell within \pm 2 standard deviations of the EA glass's accepted boron release rate. 


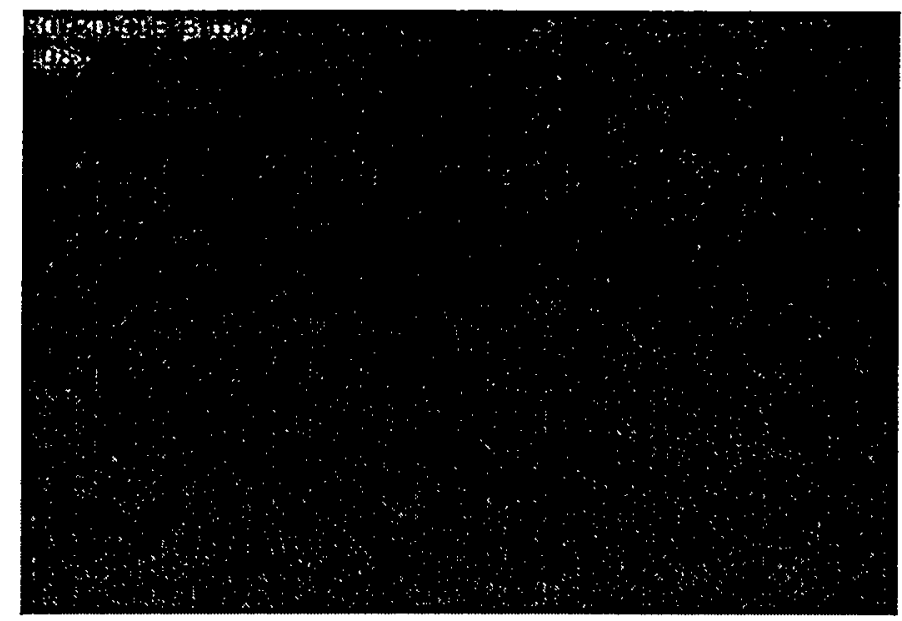

A) $80 \% W C P$ Purex $/ 20 \%$ Frit 202 re-melted (top

w

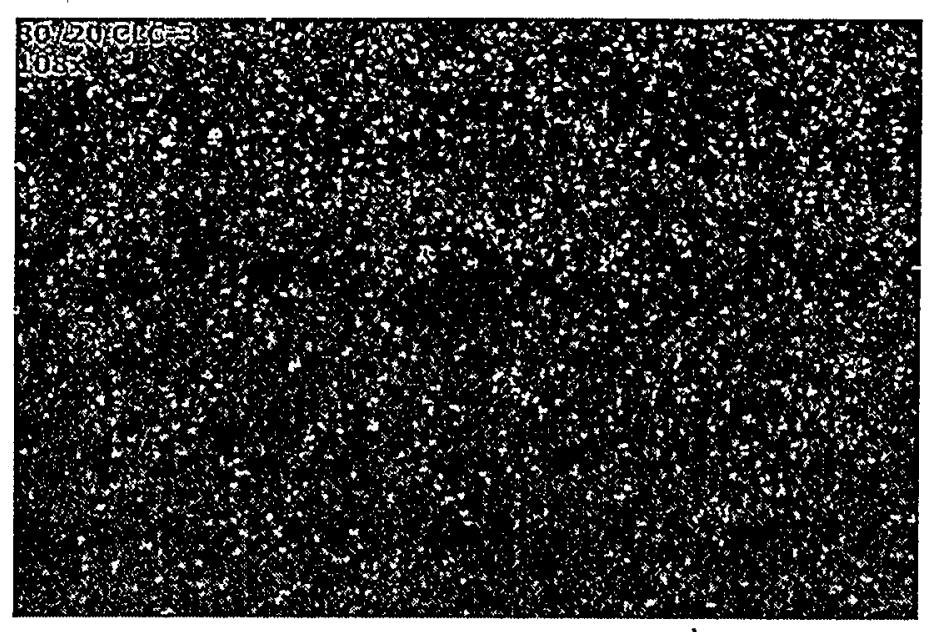

B) $80 \%$ WCP Purex/20\% Frit 202 re-melted (bottom)

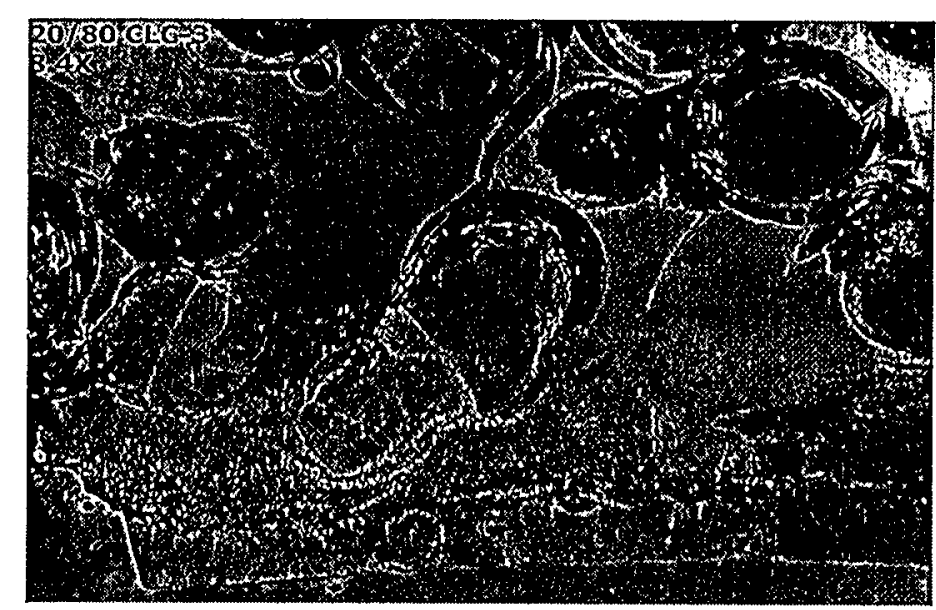

D) $20 \%$ WCP Purex/80\% Frit 202 re-melted showing crystals and crystal development at crucible interface. crystals in the glass matrix.

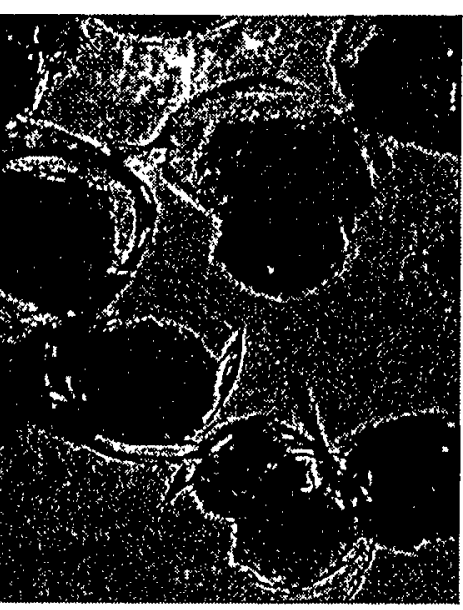

C) $20 \% \mathrm{WCP}$ Purex $/ 80 \%$ Frit 202 re-melted showing

Figure 16. Optical micrographs showing the WCP-Purex/Frit 202 glass after crushing and re-melting using the centerline cooling schedule for a second time. 


\section{A) 90/10 SCC-3 @ 8.4X}

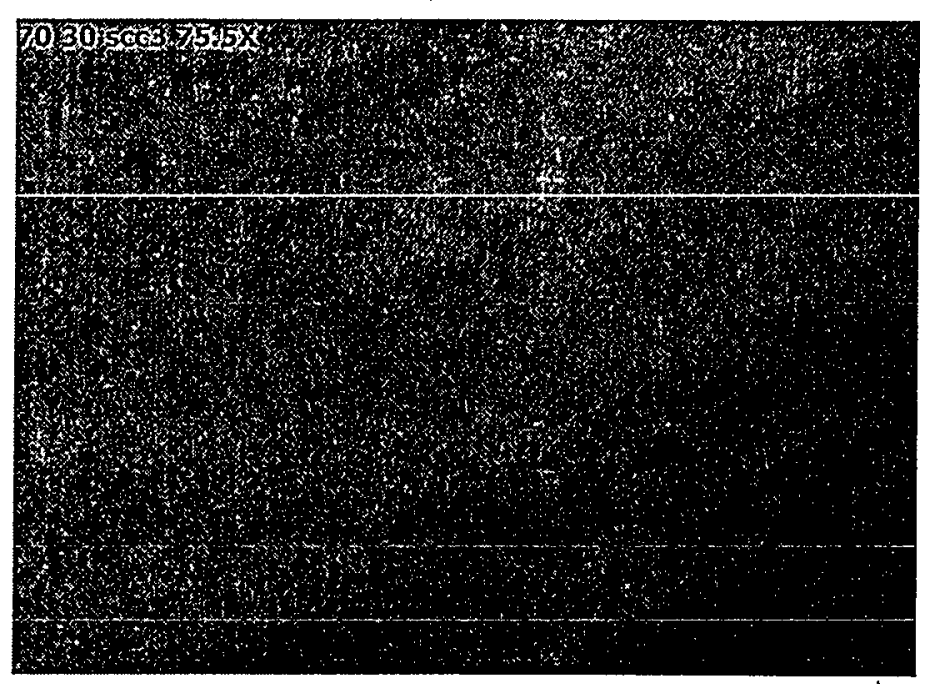

C) 70/30 SCC-3 @75.5X (WATER)

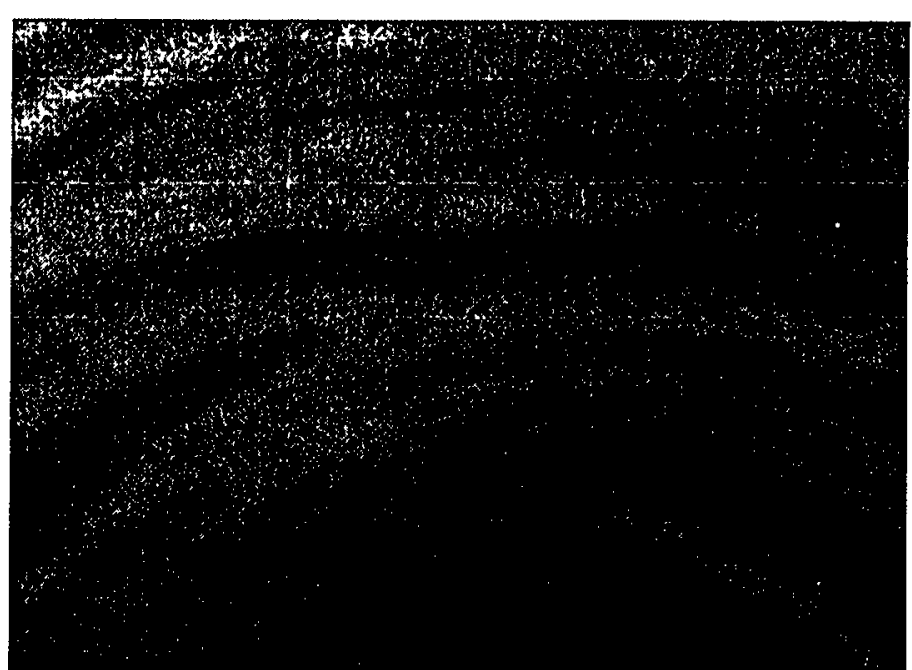

B) 70/30 SCC-3 ALL (WATER)

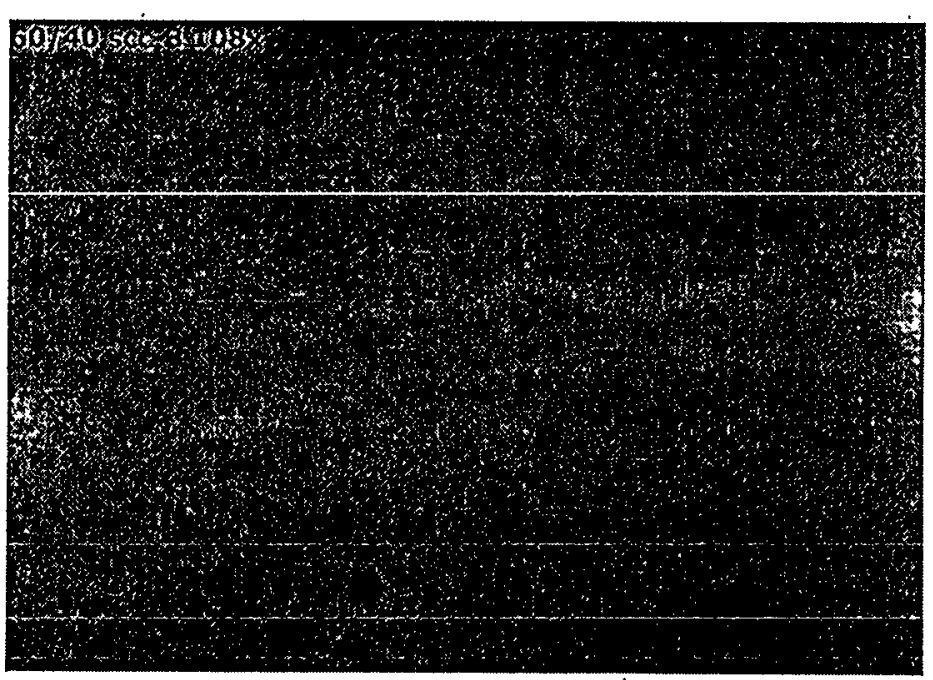

D) $60 / 40$ SCC-3 @ 108X

Figure 17. Optical micrographs of the previously melted/cooled SCC glasses that were crushed, re-melted and poured into graphite crucibles prior to being subjected to the surface cooling schedule for a second time. 
WSRC-TR-2000-00010, Revision 0
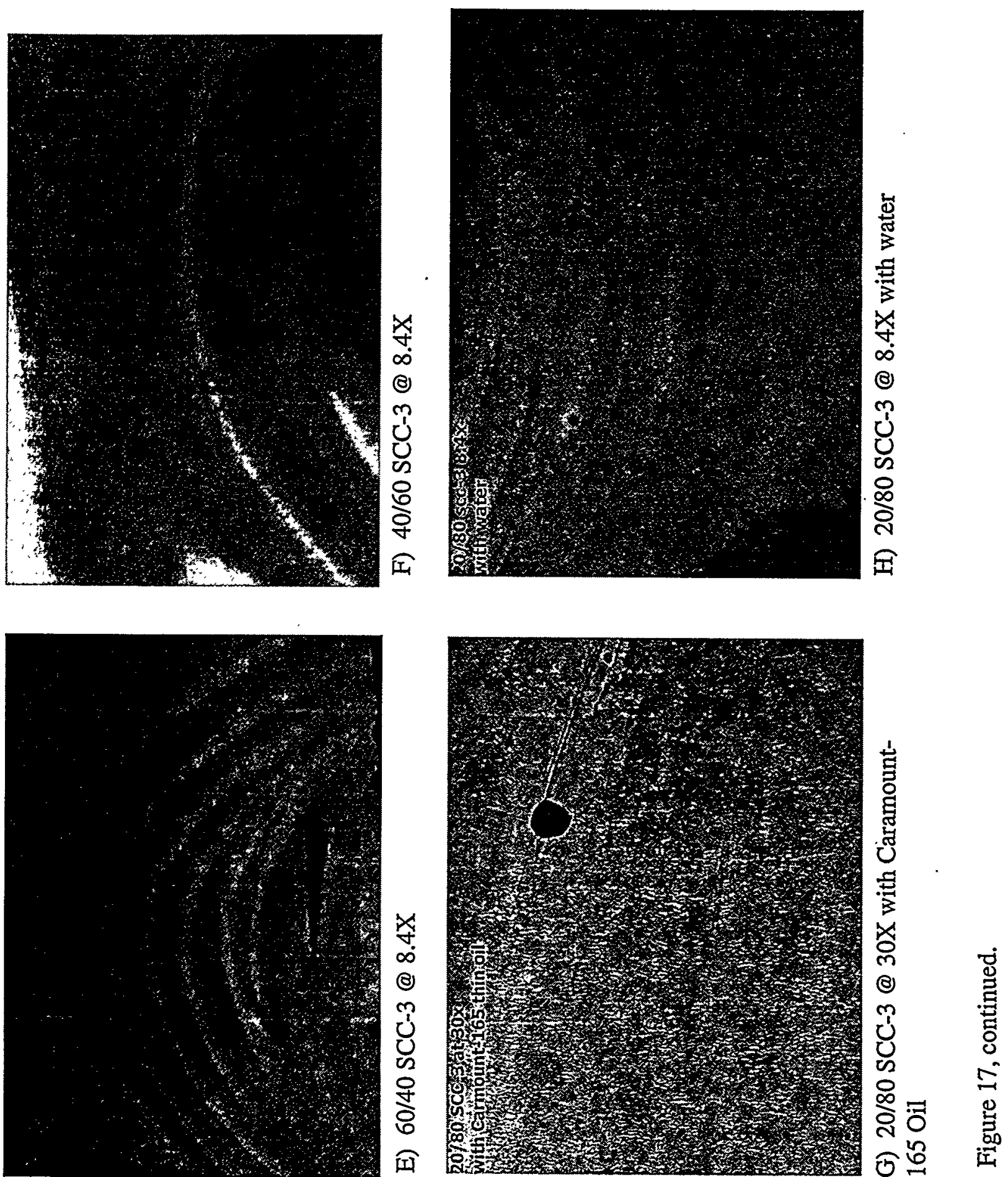


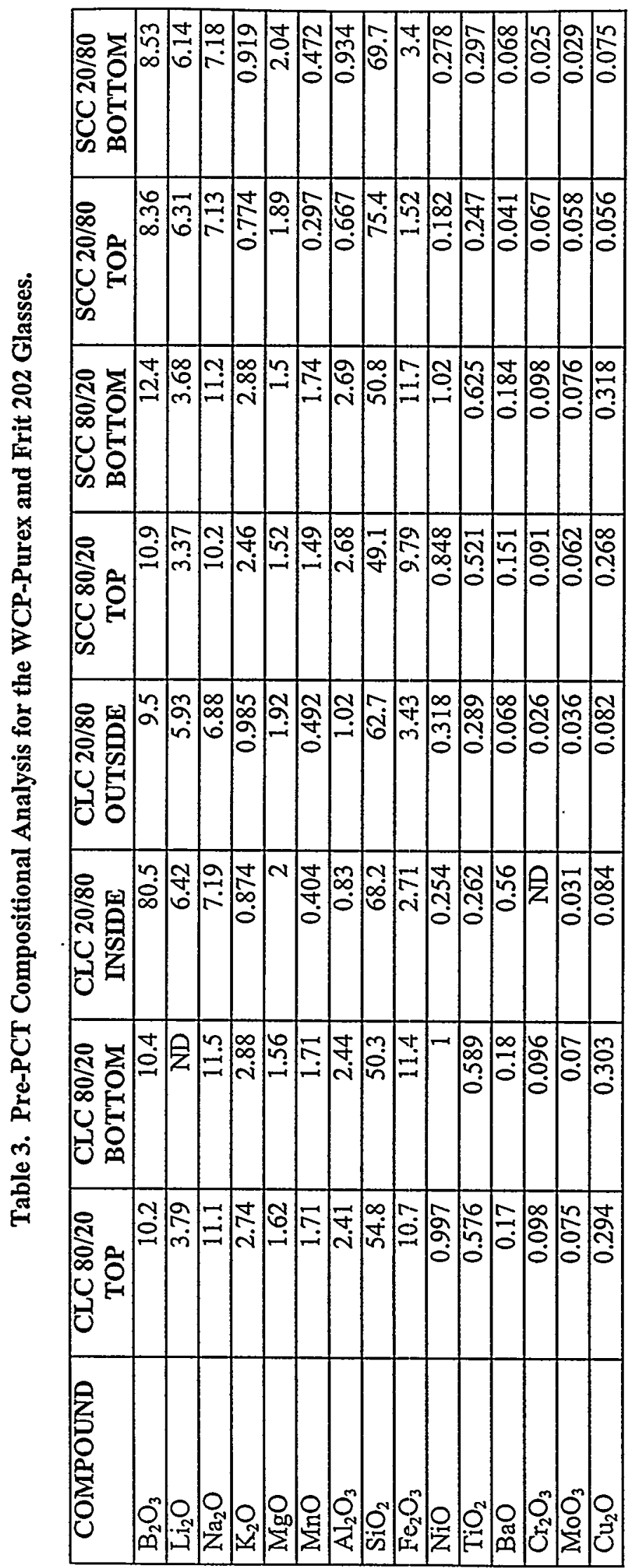


Table 4. Density Measurements for DWPF Type Borosilicate Glasses using Simulated Centerline and Surface Cooling Schedules.

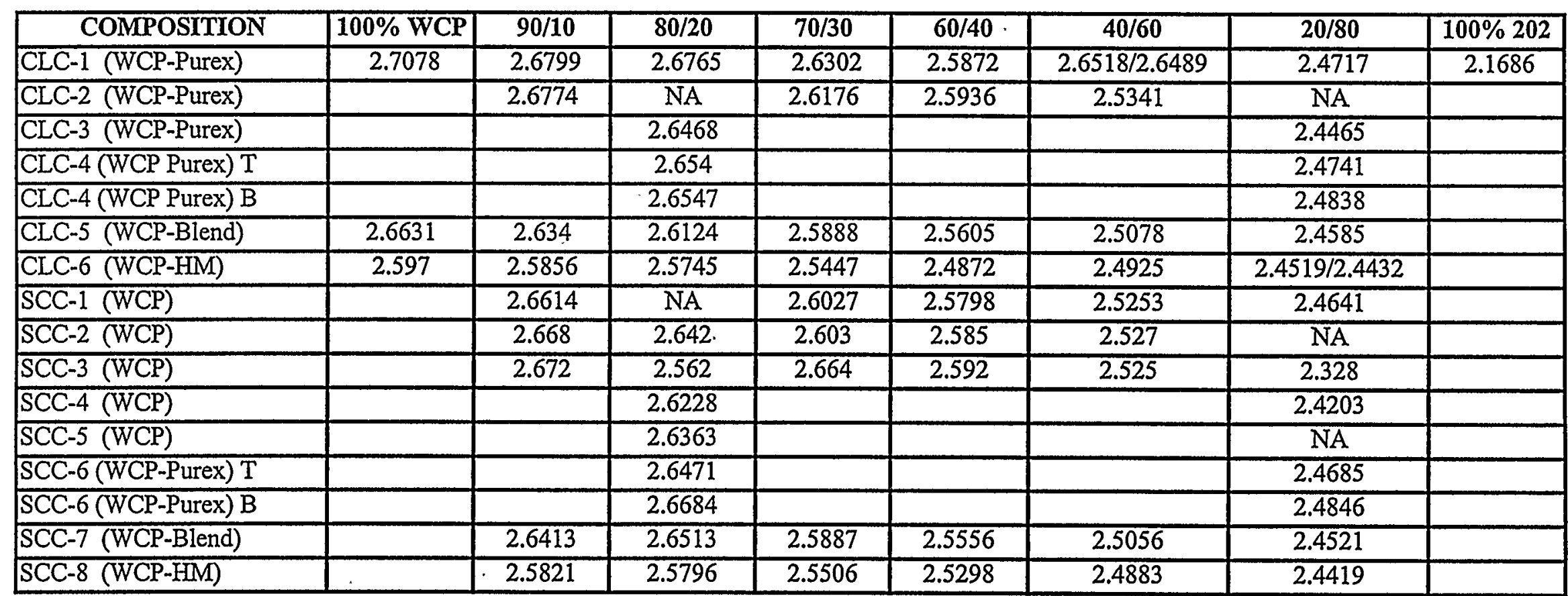




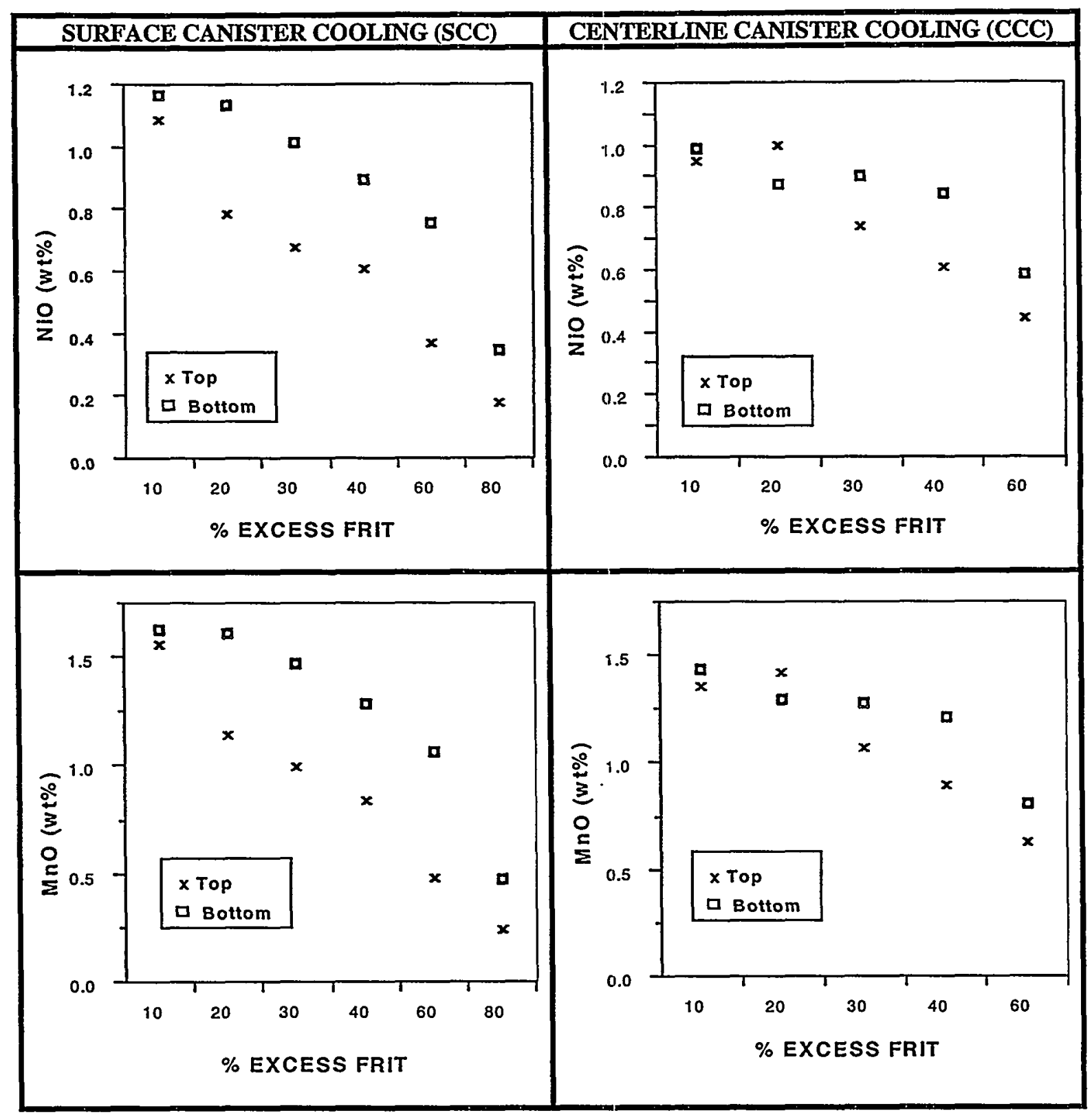

Figure 18. Graphic representation of elemental partitioning in top and bottom layers of the CLC and SCC glasses. Transition metal oxides partition into denser bottom phase. 


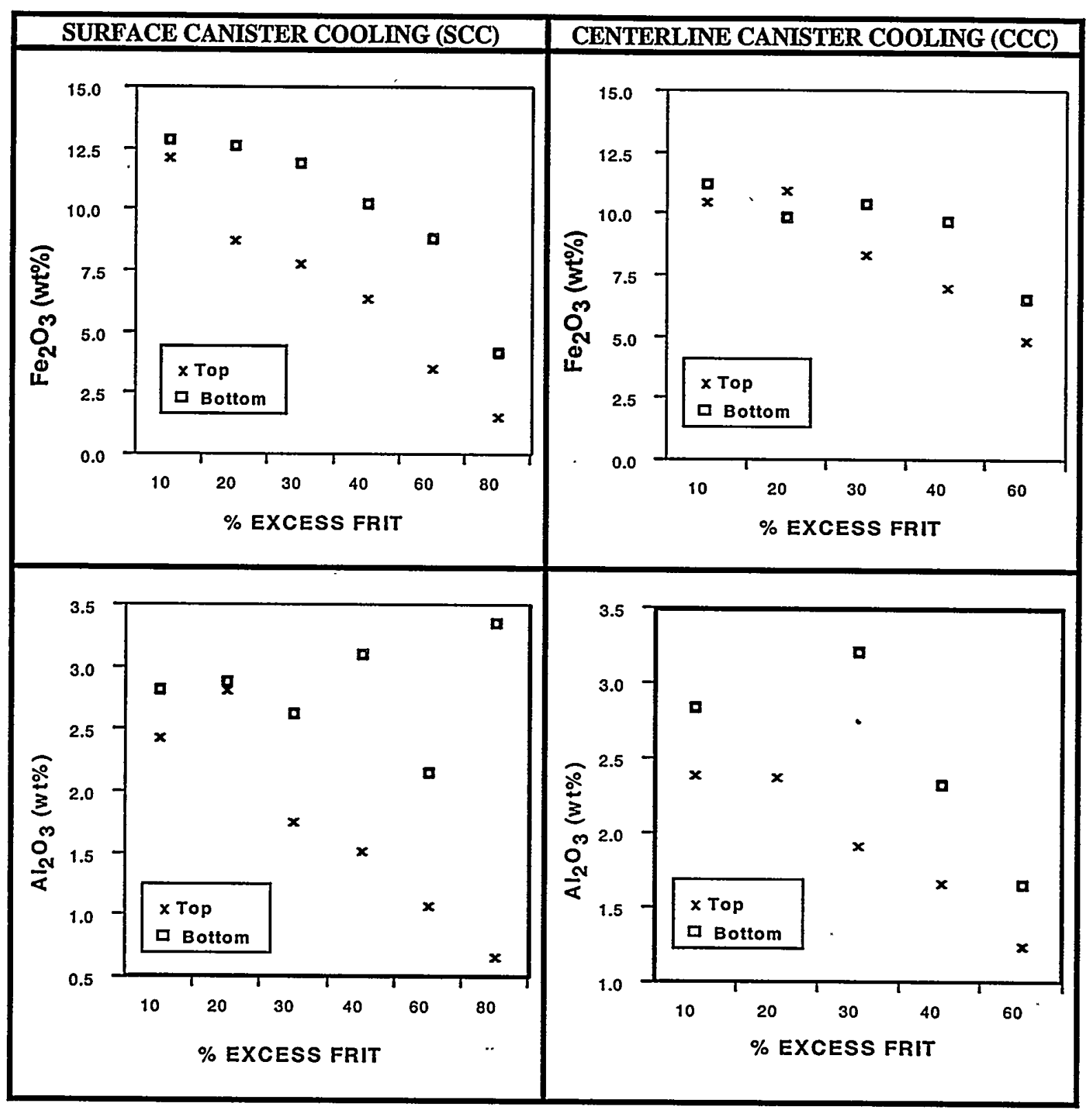

Figure 19. Graphic representation of elemental partitioning in top and bottom layers. Alumina and iron oxide partition into the denser phase. 


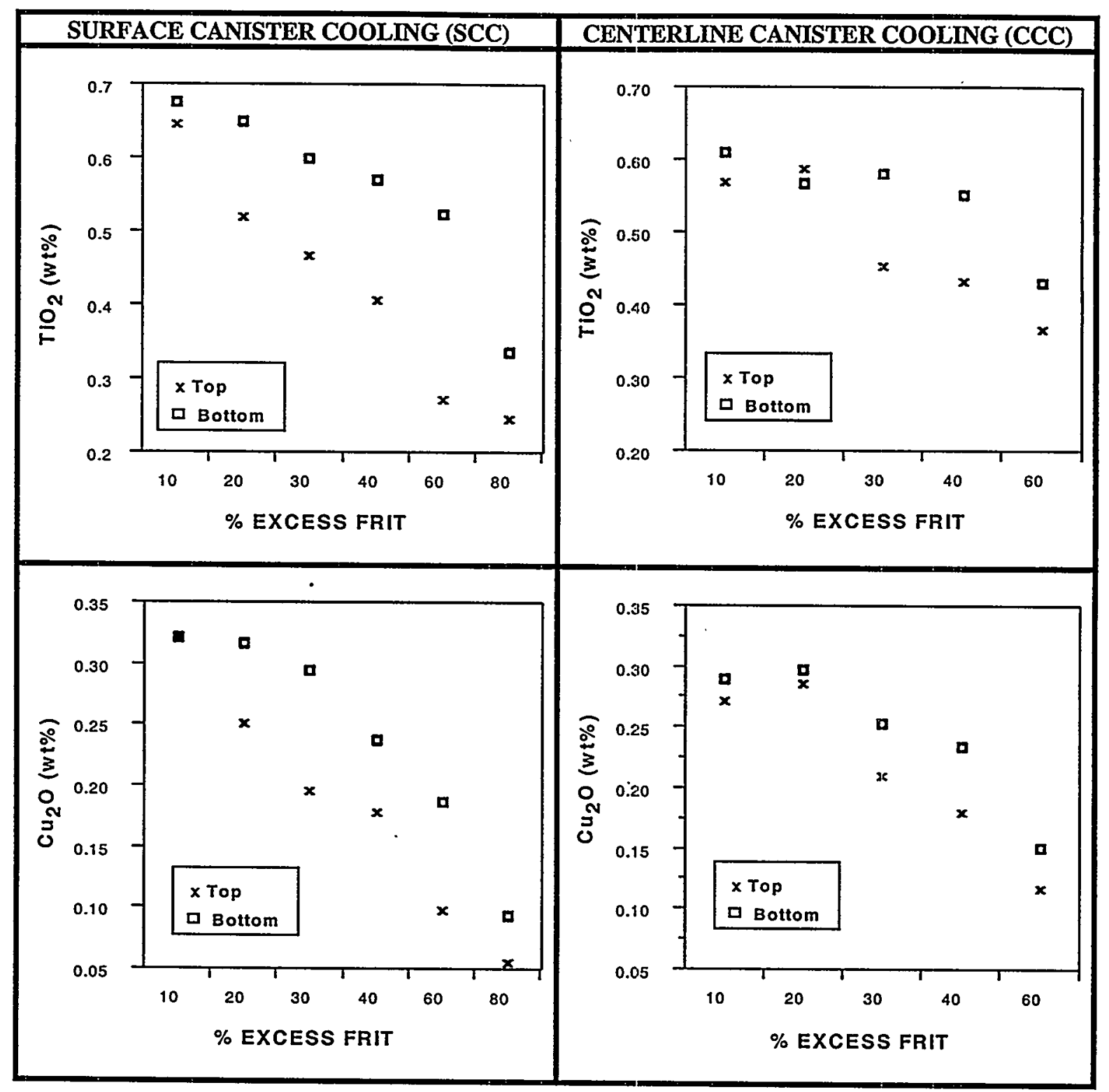

Figure 20. Graphic representation of elemental partitioning in top and bottom layers. Titanium and copper oxide partition into the denser phase. 


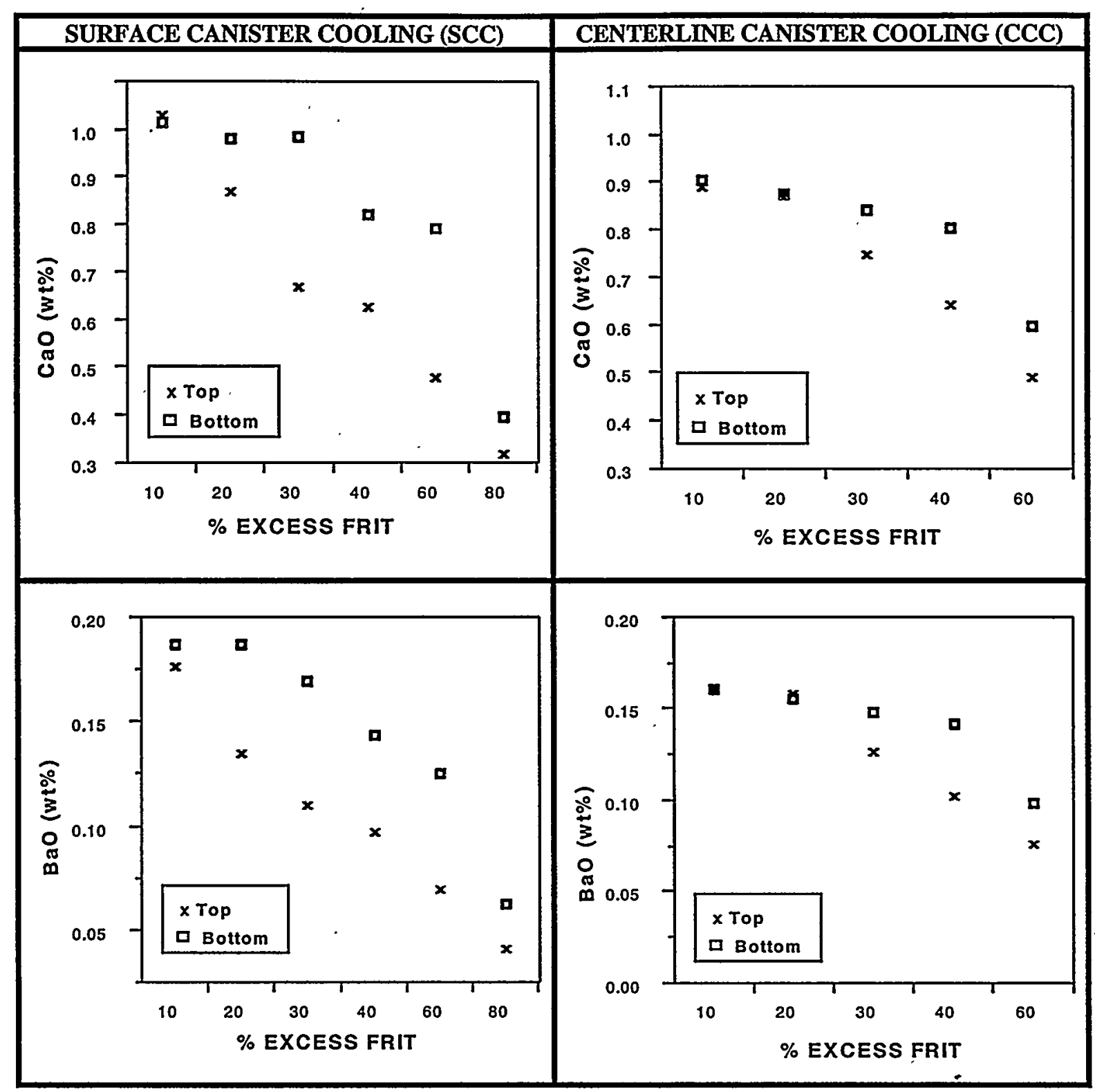

Figure 21. Graphic representation of elemental partitioning in top and bottom layers. Heavy minor constituents partition into the denser phase. 


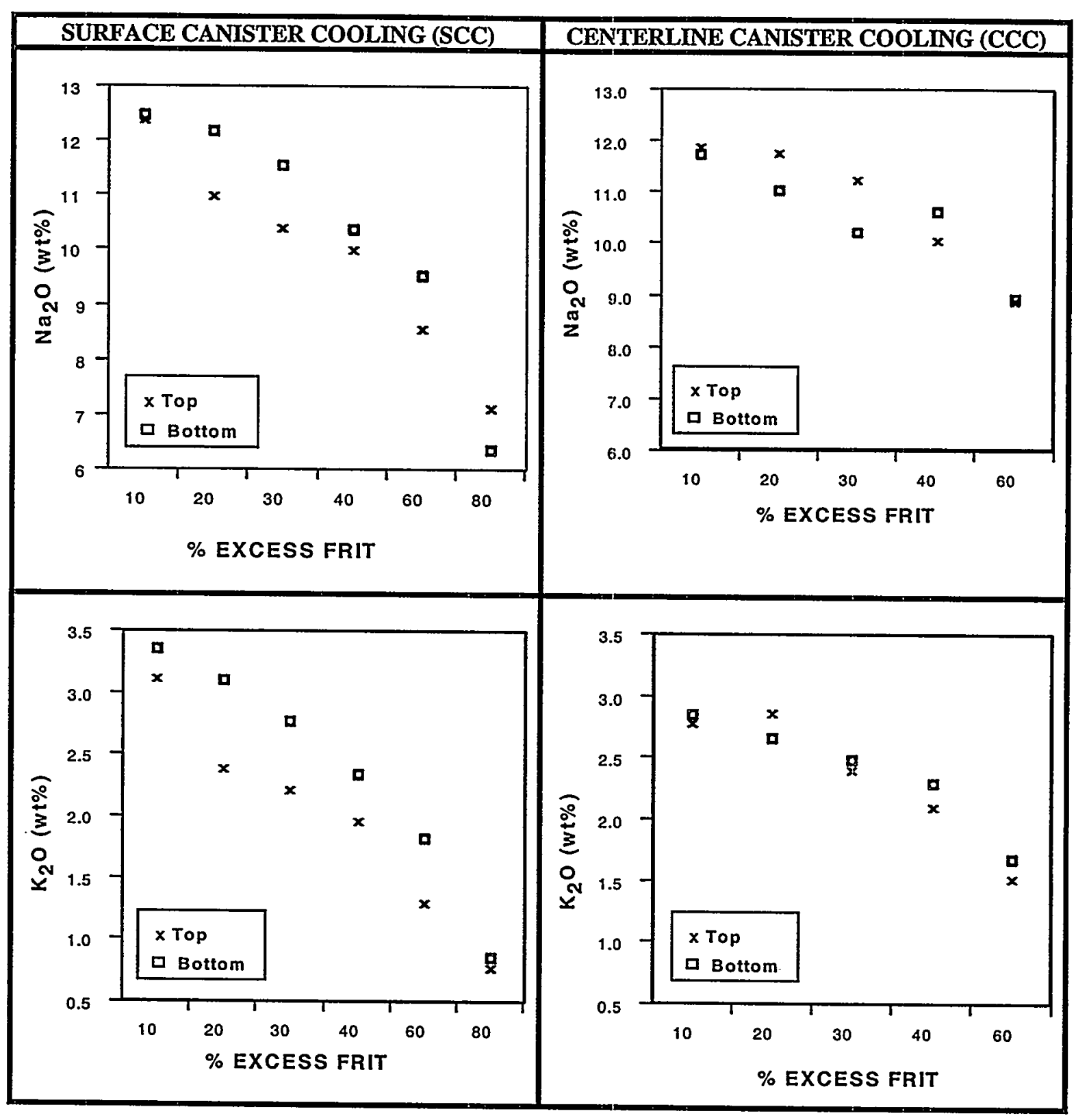

Figure 22. Graphic representation of elemental partitioning in top and bottom layers. Larger alkalis partition into the denser phase 
WSRC-TR-2000-00010, Revision 0

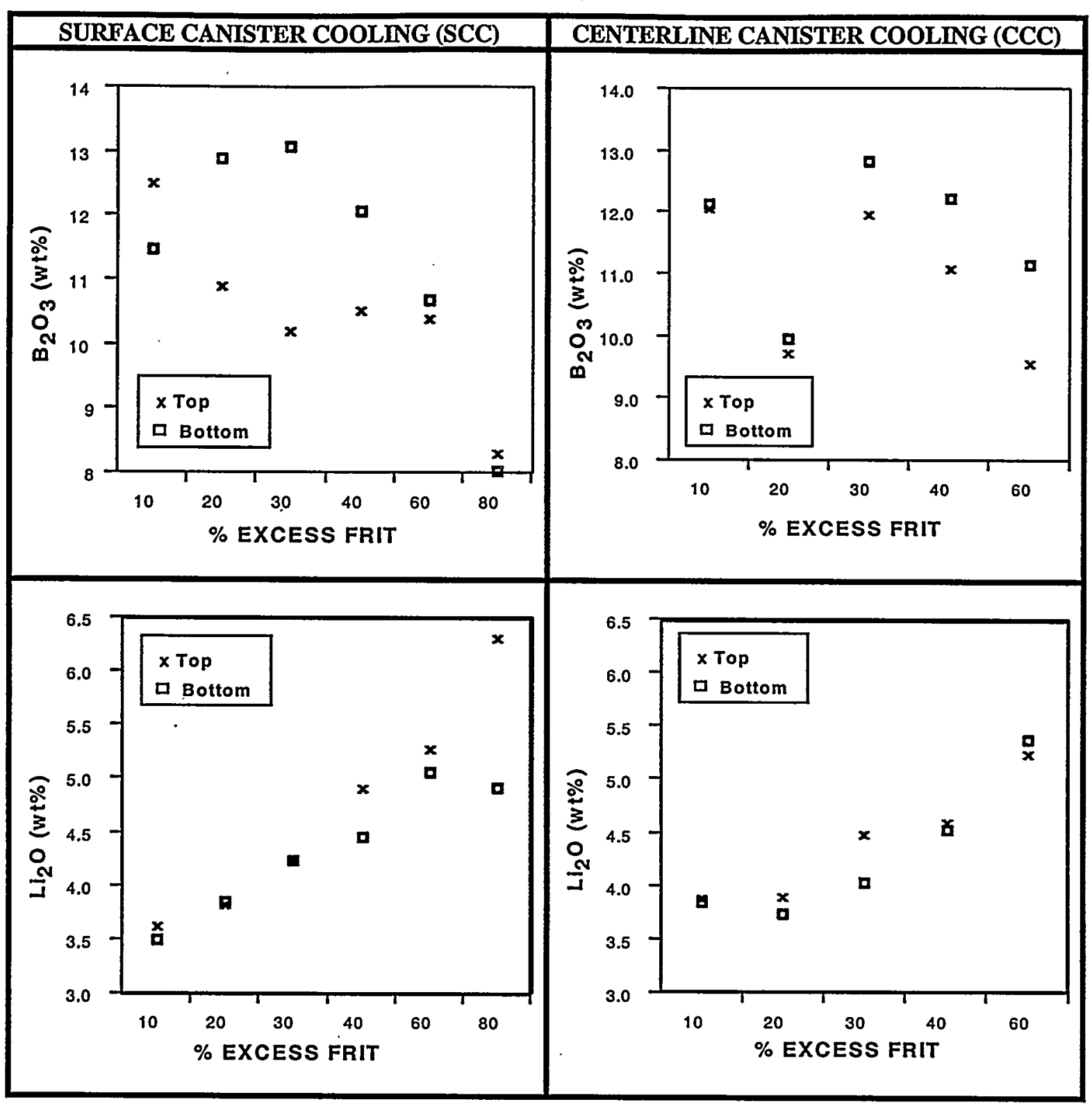

Figure 23. Graphic representation of elemental partitioning in top and bottom layers. Boron oxide partitions to the denser phase, however lithium partitions equally. At higher frit loadings a different phase may be developing. 


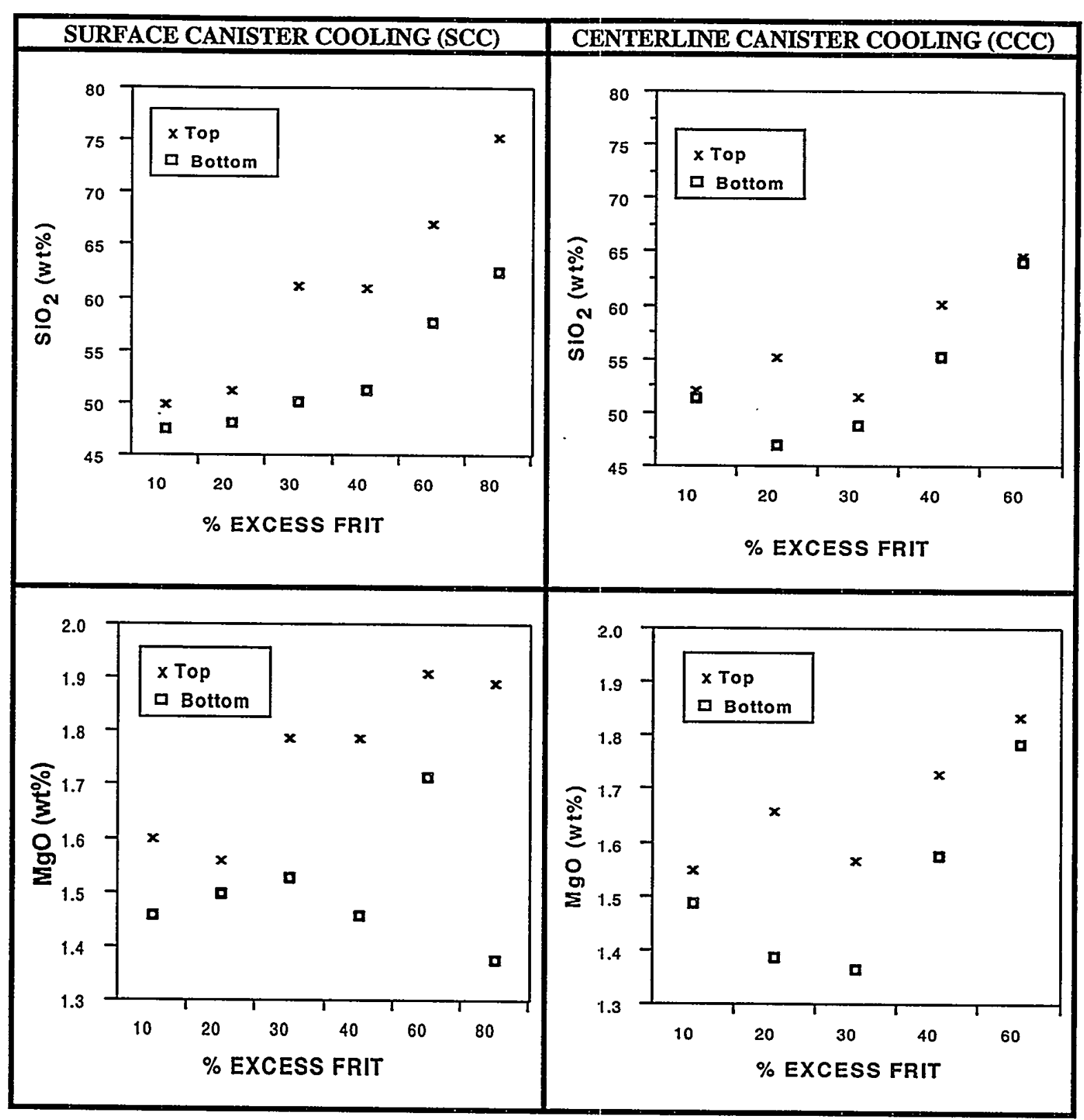

Figure 24. Graphic representation of elemental partitioning in top and bottom layers. Silica and magnesium oxide partition into the less dense phase. 
WSRC-TR-2000-00010, Revision 0

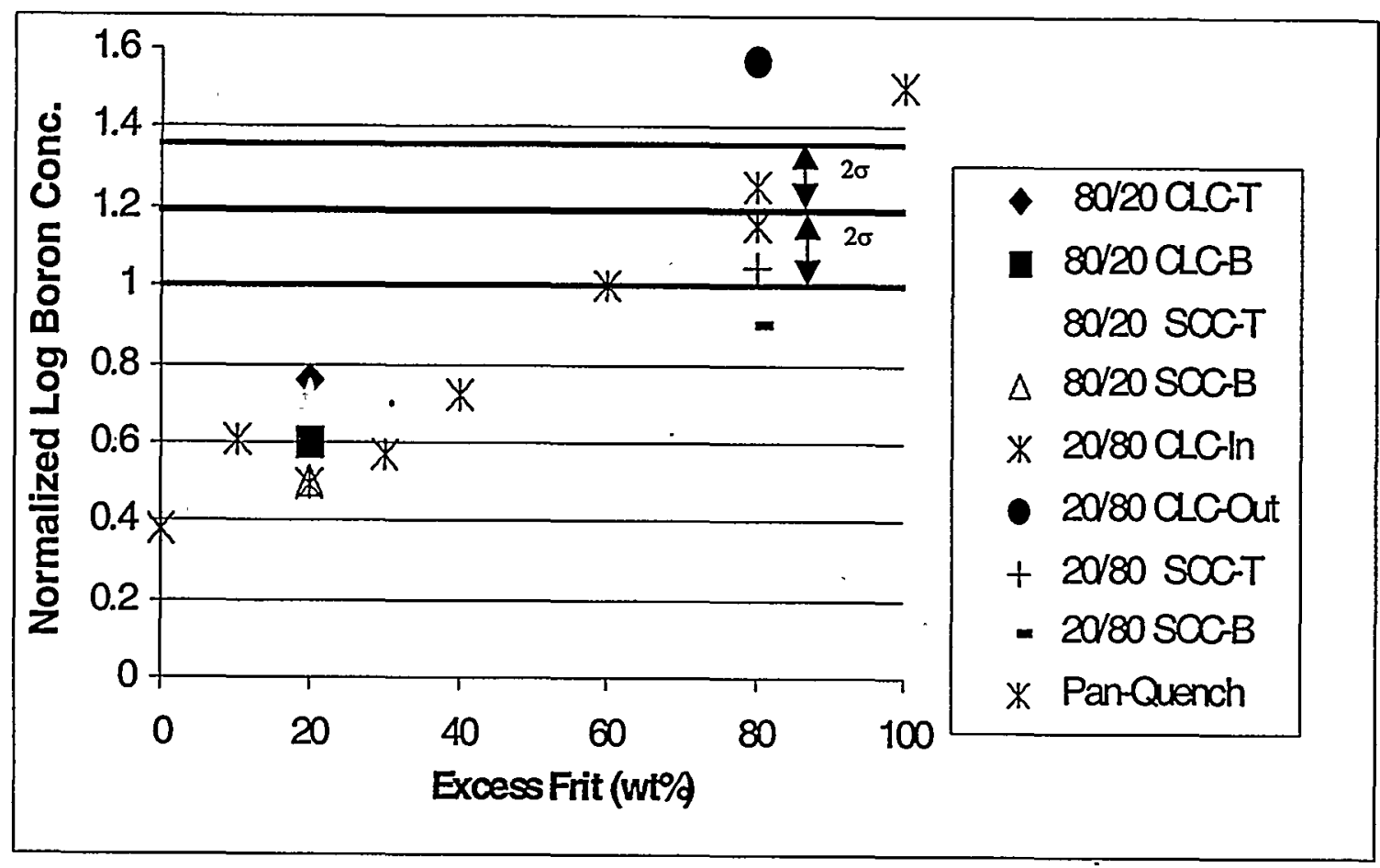

Figure 25. Summary of the PCT data for CLC, SCC and pan-quenched WCP-Purex/Frit 202 glasses. 
(inner portion of the 20/80 centerline cooled sample and the top of the 20/80 surface cooled sample) and would also be considered unacceptable according to DWPF waste acceptance criteria $^{22}$. Of the glasses tested, only two Purex glasses mixed with excess frit fell within the waste acceptance requirements. These were the 80/20 CLC and the 80/20 SCC.

\subsection{INEEL Phase Separations}

In phosphate containing borosilicate waste glasses all three major glass formers are present in structural tetrahedral or trigonal groups, e.g. $\left(\mathrm{SiO}_{4}\right)^{-4},\left(\mathrm{BO}_{4}\right)^{-5},\left(\mathrm{BO}_{3}\right)^{-3}$, and $\left(\mathrm{PO}_{4}\right)^{-3}$. The competition for dominant structural role causes one or more of the three types of tetrahedral units to phase separate, e.g. in borosilicate glasses, $\left(\mathrm{PO}_{4}\right)^{-3}$ will separate first along with accompanying charge balancing cations. ${ }^{6}$ When all three structural anionic groups are present, as in the $\mathrm{Na}_{2} \mathrm{O}-\mathrm{B}_{2} \mathrm{O}_{3}-\mathrm{SiO}_{2}-\mathrm{P}_{2} \mathrm{O}_{5}$ system, the cation with the highest field strength, $\mathrm{P}^{+5}$, dominates the de-mixing process, and gathers alkali from the already unmixed borosilicate phase into an additional droplet phase rich in $\mathrm{P}_{2} \mathrm{O}_{5} .{ }^{6}$ Melts within these phosphate systems phase separate to crystalline solids or, on rapid quenching, as-phase separated glasses which partially crystallize (Figure 26). If the difference in the field strengths $(\Delta F)$ between the major glass forming (structural) elements exceeds 0.3 , then the phase separation will be of a crystalline and not amorphous nature according to Dietzel, ${ }^{6}{ }^{6}$ e.g. the differences between $\mathrm{B}$ and $\mathrm{P}$ and $\mathrm{Si}$ and $\mathrm{P}$ exceed the limit of 0.3 while the $\Delta \mathrm{F}$ difference between $\mathrm{B}$ and $\mathrm{Si}$ is only 0.06 . Therefore, the phase separation in phosphate systems is of a crystalline nature (easily detected by techniques such as $\mathrm{x}$-ray diffraction) while phase separation in borosilicates is of an amorphous-amorphous nature.

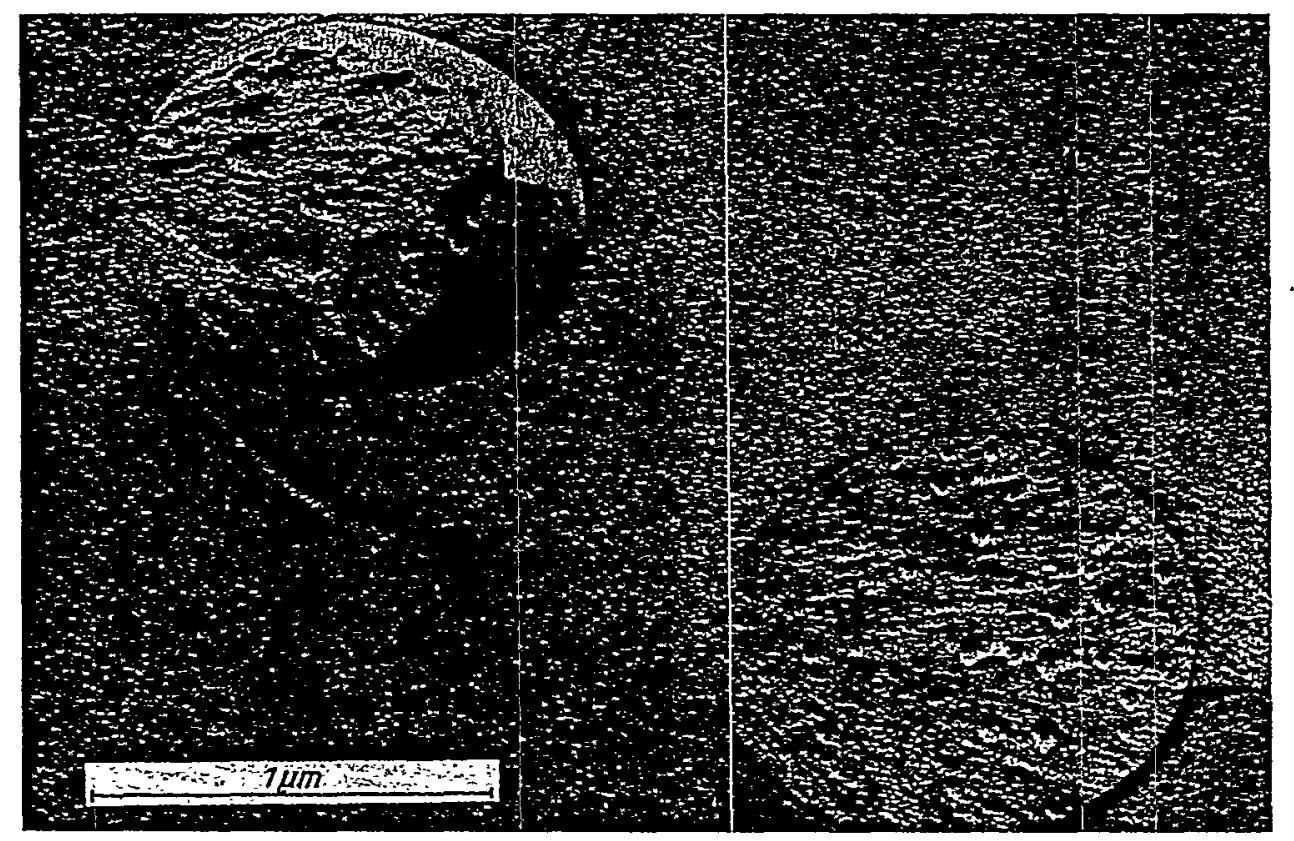

Figure 26. $\mathrm{CaO}-\mathrm{P}_{2} \mathrm{O}_{5}$ rich droplets which have crystallized in a phosphate rich borosilicate glass (from 
Vogel, ref. ${ }^{6}$ ).

A large amount of data on high $\mathrm{Al}_{2} \mathrm{O}_{3}$, high $\mathrm{Na}_{2} \mathrm{O}$, low $\mathrm{Fe}_{2} \mathrm{O}_{3}$ borosilicate waste glasses containing 1$5 \mathrm{wt} \% \mathrm{U}_{3} \mathrm{O}_{8}$ was generated by SRTC during the vitrification of the SRS M-Area mixed (hazardous and radioactive) wastes. In particular, several tanks of this mixed waste contained high phosphate while several tanks were almost phosphate free. A pilot scale melter run was performed under funding from the Mixed Waste Focus Area (EM-50). This waste campaign was initiated with low phosphate tank waste. Subsequently, high phosphate containing waste was fed to the melter. The amount of phosphate in the final glass was analyzed chemically and the glasses were analyzed by XRD. The glasses made at the beginning of the campaign had $2.40 \% \mathrm{P}_{2} \mathrm{O}_{5}$ before the high $\mathrm{P}_{2} \mathrm{O}_{5}$ waste was fed to the melter. At $\geq 2.76$ wt\% $\mathrm{P}_{2} \mathrm{O}_{5}$ a Li $\mathrm{Li}_{2} \mathrm{PO}_{4}$ phase began to precipitate indicating that the crystalline phase separation begins at $\sim 2.5 \mathrm{wt} \% \mathrm{P}_{2} \mathrm{O}_{5}$ (see horizontal line of demarcation in Figures $27 \mathrm{a}$ and b) in agreement with the 1986 data of Jantzen on DWPF type borosilicate glasses containing $\mathrm{P}_{2} \mathrm{O}_{5}$. Note that the high $\mathrm{Al}_{2} \mathrm{O}_{3}$ content (Figure $26 \mathrm{~b}$ ), in excess of $13 \mathrm{wt} \% \mathrm{Al}_{2} \mathrm{O}_{3}$, does not suppress this type of phase separation as it does in phase separated borosilicate systems ${ }^{6}$.
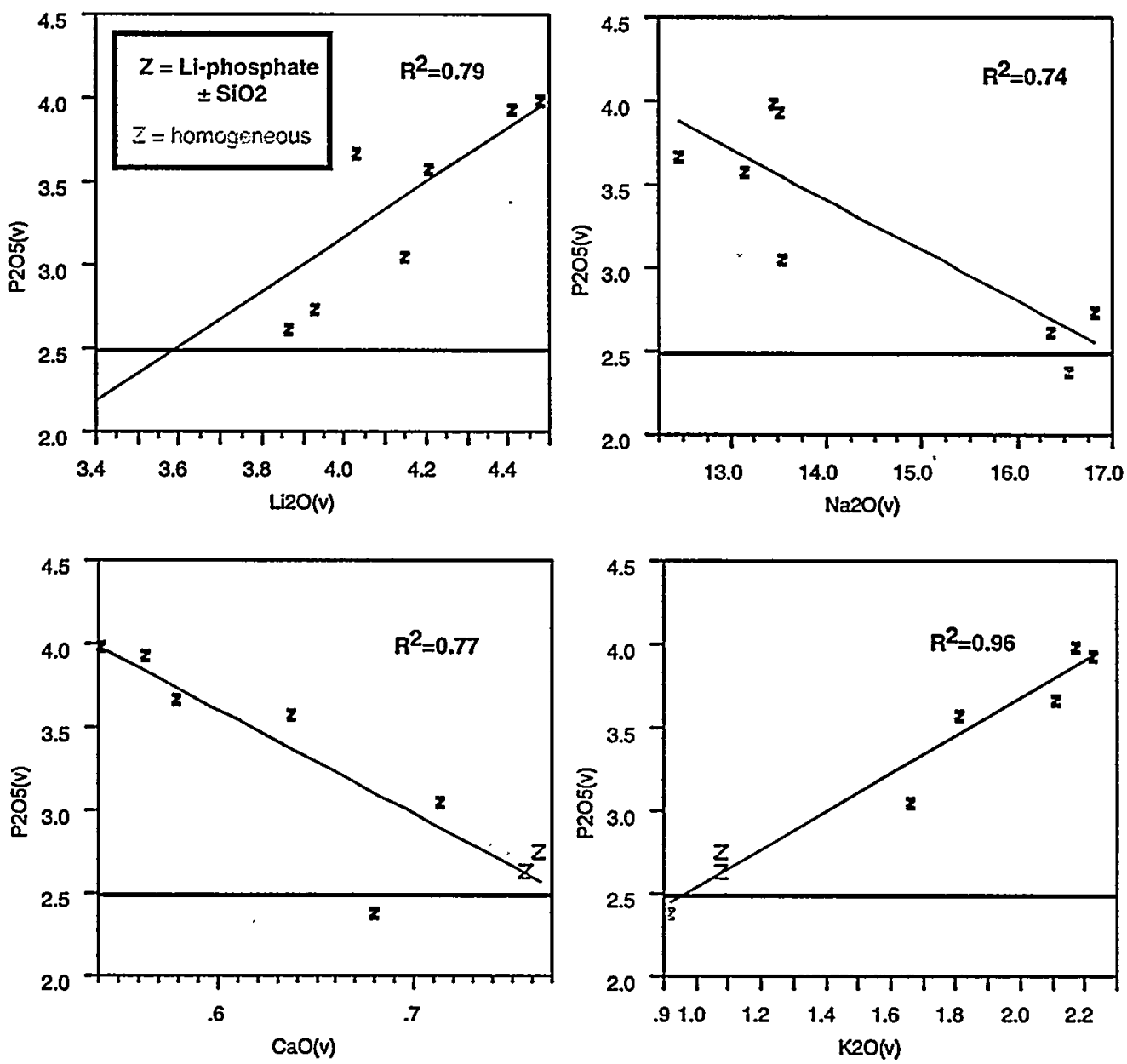

Figure 27a. Phosphate glass crystalline phase separation exhibited in pilot scale melter runs of a high $\mathrm{Al}_{2} \mathrm{O}_{3}$, high $\mathrm{Na}_{2} \mathrm{O}$, high $\mathrm{U}_{3} \mathrm{O}_{8}$ containing mixed waste. $\mathrm{Li}_{2} \mathrm{O}$ in the frit additions caused a $\mathrm{LiPO}_{4}$ crystalline phase and $\mathrm{SiO}_{2}$ to crystallize during phase separation rather than a sodium or calcium phosphate phase. 

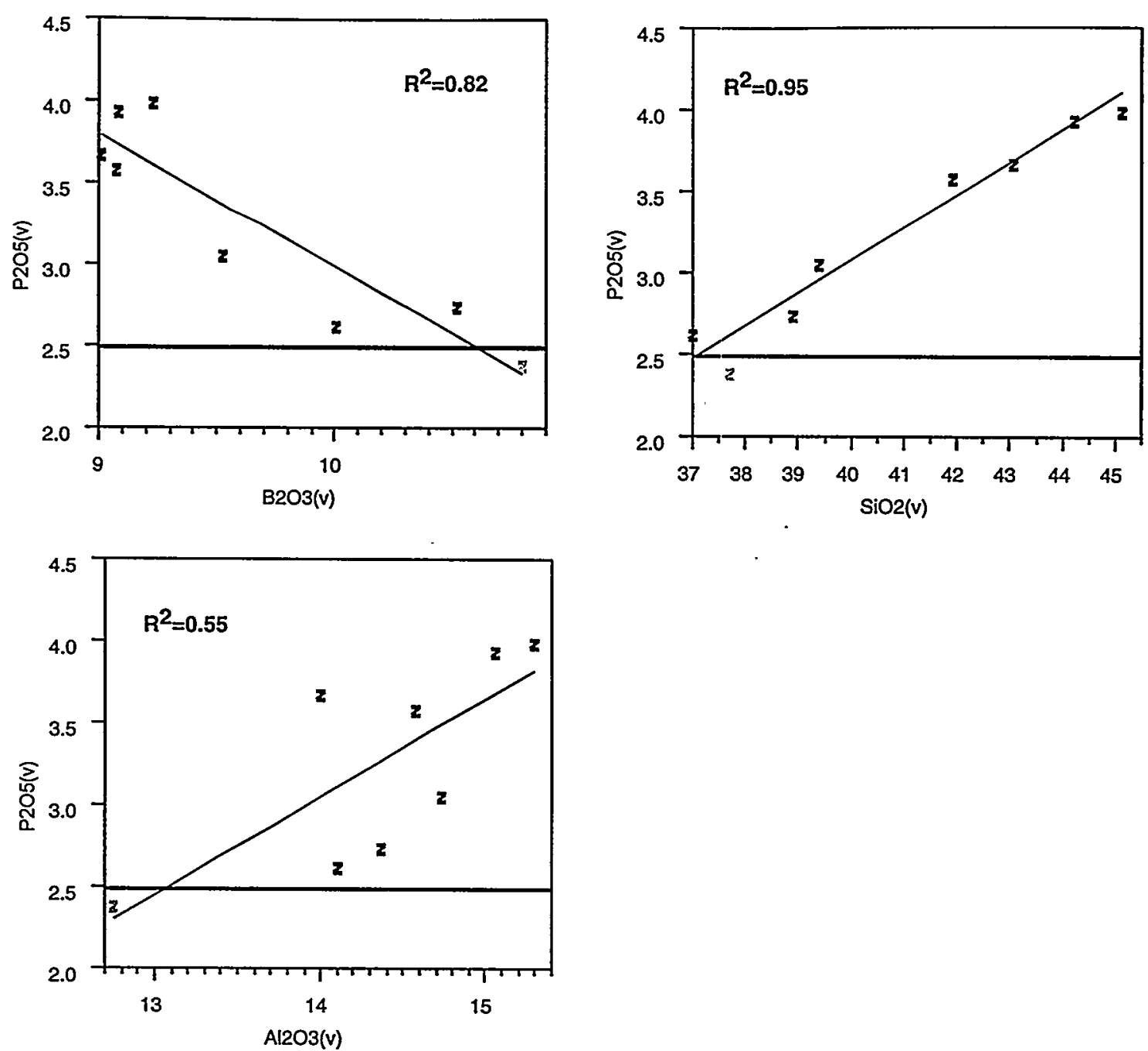

Figure 27b. Phosphate glass crystalline phase separation exhibited in pilot scale melter runs of a high $\mathrm{Al}_{2} \mathrm{O}_{3}$, high $\mathrm{Na}_{2} \mathrm{O}$, high $\mathrm{U}_{3} \mathrm{O}_{8}$ containing mixed waste. $\mathrm{Li}_{2} \mathrm{O}$ in the frit additions caused a $\mathrm{LiPO}_{4}$ crystalline phase and $\mathrm{SiO}_{2}$ to crystallize during phase separation rather than a sodium or calcium phosphate phase.

The melter campaign data was merged with other crucible study data on the M-area mixed waste glasses with and without $\mathrm{P}_{2} \mathrm{O}_{5}$ (a total of 42 glasses). Data on simple borosilicate glasses with and without $\mathrm{P}_{2} \mathrm{O}_{5}$ were also taken from the data of Cozzi (6 glasses). ${ }^{20}$ Data pertinent to INEEL wastes was taken from Staples, et al. (44 glasses) $)^{15}$. While data pertinent to Hanford wastes was taken from the data of Langowski, Li, et al. (4 glasses) ${ }^{23}$. Initial work on the identification of the crystalline phase separated phase was reported by Staples, et al. These samples (15 glasses) were secured from the authors and XRD was performed on the glasses as a part of this study. Thus, a database of 96 glass compositions was compiled. In this database, all 96 glasses had duplicate or triplicate PCT (ASTM C1285-94) durability tests performed, all 96 had been analyzed by XRD for crystalline phase separation, and 86 of the 96 glasses had been analyzed chemically. For the remaining 10 glasses, as-batched glass compositions were used in the database.

Analysis of the chemistry of the glasses in the database supported the data from the melter campaign: glasses with greater than $\sim 2.5$ wt\% $\mathrm{P}_{2} \mathrm{O}_{5}$ underwent crystalline phase separation of some type of alkali or alkaline earth phosphate phase with or without crystallization of an $\mathrm{SiO}_{2}$ rich phase (Figure 
27). PCT durability of the crystalline phase separated $\mathrm{P}_{2} \mathrm{O}_{5}$ glasses versus the homogeneous $\mathrm{P}_{2} \mathrm{O}_{5}$ glasses indicated that there were many homogeneous glasses that were poorly durable and performed at or below the EA glass limit in terms of their normalized B release (Figure 28). Conversely, there were crystalline phase separated $\mathrm{P}_{2} \mathrm{O}_{5}$ glasses that were very durable, as durable as the low $\mathrm{P}_{2} \mathrm{O}_{5}$ containing homogeneous glasses. These glasses are encircled in Figure 29. Therefore, the appearance of $\mathrm{P}_{2} \mathrm{O}_{5}$ crystalline phase separation is not causing adverse effects on the borosilicate glass durability. This is analogous to the lack of impact of spinel crystallization on borosilicate glass durability observed by Jantzen and Bickford ${ }^{24}$ in DWPF type glasses. Examination of the leachates for these 96 glasses indicates that the strong base formers (alkalis) and weak acid formers (boria and silica) in the $\mathrm{P}_{2} \mathrm{O}_{5}$ containing homogeneous and phase separated glasses are dominating the glass durability and not the $\mathrm{P}_{2} \mathrm{O}_{5}$ crystalline phase separation (Figure 30).

In summary, due to the crystalline nature of the $\mathrm{P}_{2} \mathrm{O}_{5}$ phase separation, crystalline $\mathrm{P}_{2} \mathrm{O}_{5}$ rich phases should be treated as a crystallization effect rather than as a phase separation effect. The formation of these crystalline phases shows that some glass compositions containing up to $\sim 19$ wt\% $\mathrm{P}_{2} \mathrm{O}_{5}$ are durable even though they have undergone phase separation/crystallization. The data supports that the major glass components (alkalis, silica, and boria) are controlling the glass durability and not the crystallization phase separation. An examination of the durable glasses encircled in Figure 29 indicates that $\mathrm{Al}_{2} \mathrm{O}_{3}$ does not impact the formation of the crystalline $\mathrm{P}_{2} \mathrm{O}_{5}$ phase separation but increased $\mathrm{Al}_{2} \mathrm{O}_{3}$ does enhance the glass matrix durability.
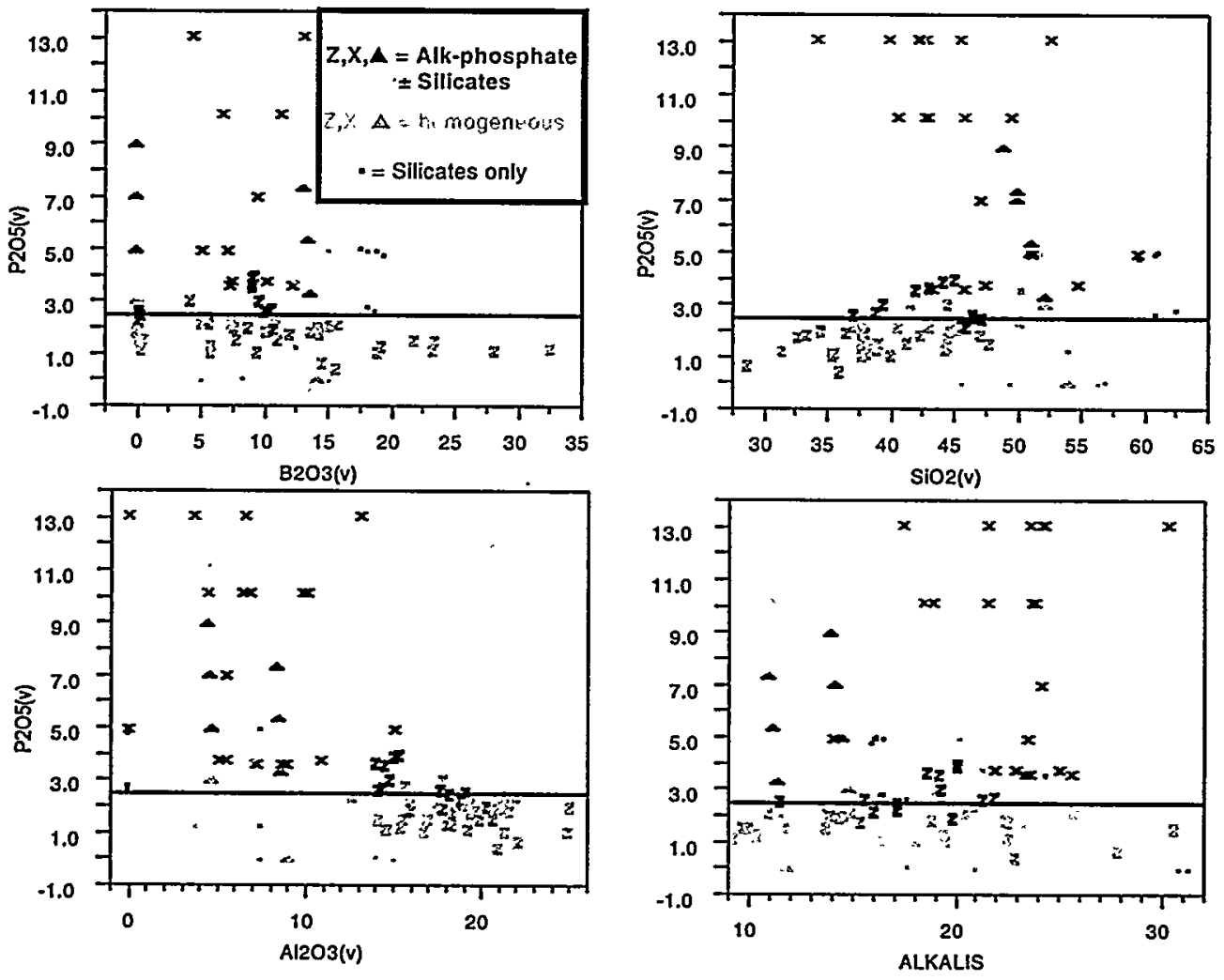

Figure 28. Data from 96 borosilicate waste glasses containing varying amounts of $\mathrm{P}_{2} \mathrm{O}_{5}$ indicates that glasses with $\geq 2.5 \mathrm{wt} \% \mathrm{P}_{2} \mathrm{O}_{5}$ undergo crystalline phase separation of $\mathrm{P}_{2} \mathrm{O}_{5}$-rich and/or $\mathrm{SiO}_{2}$-rich phases. 
WSRC-TR-2000-00010, Revision 0
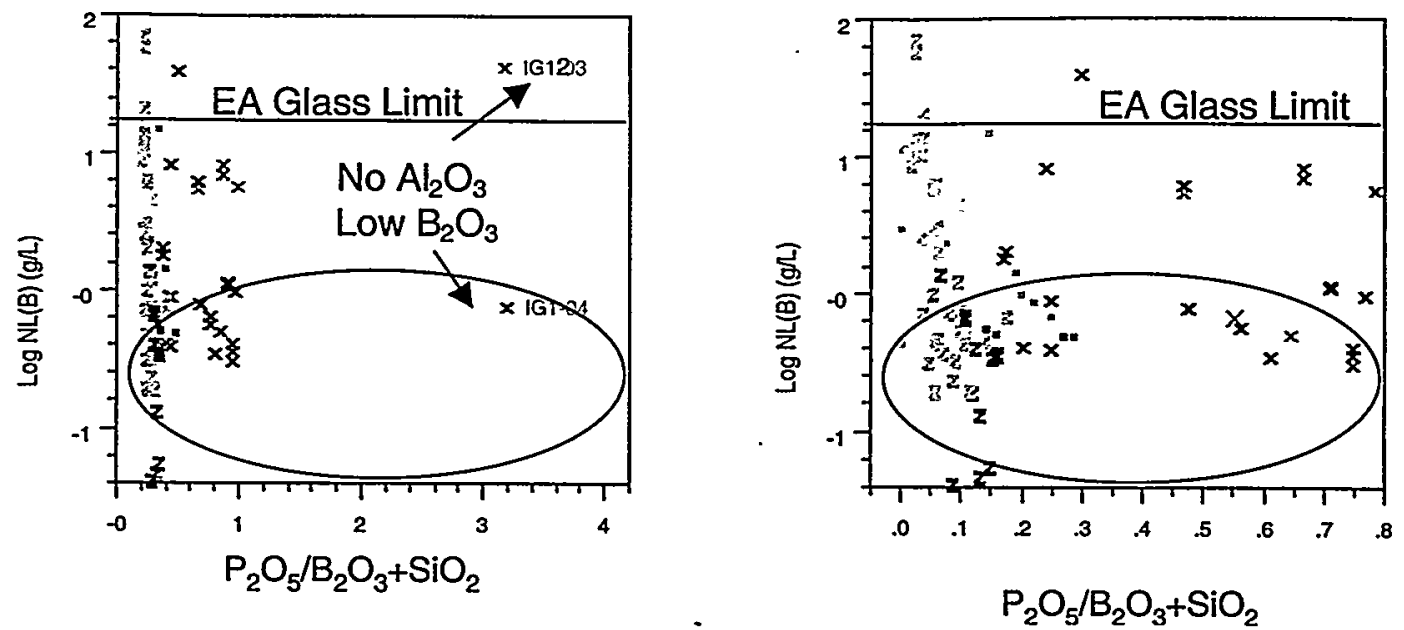

Figure 29. Both homogeneous and phase separated glasses borosilicate waste glasses containing $\mathrm{P}_{2} \mathrm{O}_{5}$ can be made to be more durable than the Environmental Assessment glass during PCT (ASTM C1285) analysis. Glasses containing up to $19 \mathrm{wt} \% \mathrm{P}_{2} \mathrm{O}_{5}$ (encircled) are durable even though they have undergone crystalline phase separation.

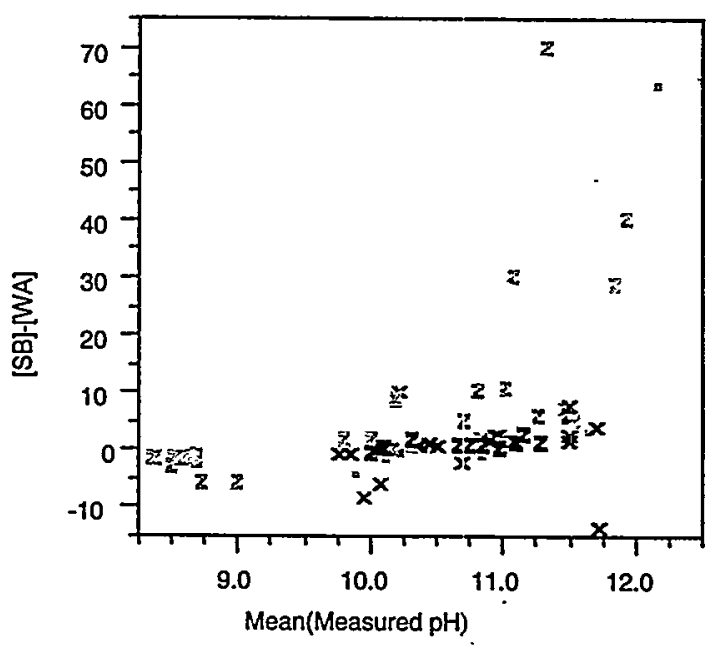

Figure 30. Glass durability is shown to be a function of the strong bases (alkalis) and weak acid (silica and boria) in the glass and leachate rather than a function of the crystalline phase separation. 


\subsection{CONCLUSIONS}

$>$ There appears to be two types of phase separation occurring in the borosilicate waste glasses studied, amorphous and crystalline. Amorphous phase separation (APS) is observed in borosilicate waste glasses with $\leq 2.5 \mathrm{wt} \% \mathrm{P}_{2} \mathrm{O}_{5}$ and crystalline phase separation (CPS) occurs in borosilicate waste glasses with $>\mathrm{P}_{2} \mathrm{O}_{5}$.

$>$ Amorphous phase separation appears to be detrimental to waste glass durability while CPS does not appear to have an adverse effect on durability.

$>$ Visual and optical microscopic examination reveals that APS in DWPF-type glasses appear to be macroscopic. Additional microscopic examination (SEM) failed to reveal evidence of microscopic APS. However, more intensive examination by other techniques such as SANS/SAXS or TEM may be necessary to determine if microscopic APS exists in phase separated WCP-Purex, HM or Blend glasses mixed with excess frit 202.

$>$ Optical microscopic examination of APS in pan-quenched DWPF-type glasses $(90 / 10,80 / 20$, $60 / 40$ and 20/80 wt\% WCP-Purex /Frit 202) revealed that the glasses were a mechanical mixture of the two separated phases. This implies that the immiscibility occurs at or near the melt temperature, e.g. "stable" immiscibility in the pan-quenched glasses. For the glasses examined via $\operatorname{TEM}(10,20,30,40 \mathrm{wt} \%$ excess frit glasses), microscopic phase separation was not observed.

$>$ Durability of APS glasses appears to decrease with increases in additions of phase-separated frit 202. For the glasses tested by PCT thus far, the less dense top portion of the glass appears somewhat less durable than the bottom portion whether the sample was subjected to CLC or SCC cooling. Once the composition of the glass reached the $80 \mathrm{wt} \%$ excess frit level, the durability of . the glass was no longer acceptable, regardless of the cooling schedule. A possible exception was the 80/20 SCC bottom sample. However, it should be noted this was not a statistically-based study.

$>$ There appears to be a greater degree of crystal formation in the glasses subjected to simulated centerline cooling schedules than those subjected to the simulated surface cooling regime.

$>$ From the data gathered thus far, it appears that the most applicable TTT diagram for the glasses tested is one where the phase separation nose intersects both the SCC and CLC curves and the noses of the spinel and acmite areas would only slightly intersect the CLC curve (but not the SCC curve). This corresponds to diagram " $F$ " in Figure 2 . If a glass is compositionally prone to APS, the phase separated region will appear on the TTT diagram. If the composition is not prone to APS then this region is absent from the TTT diagram.

$>$ The crystalline phase separation that forms as a result of the high phosphate content in INEEL and other waste glasses does not appear to affect the durability of the wasteform (up to 19 wt\% $\mathrm{P}_{2} \mathrm{O}_{5}$ ). It is believed that while the alumina content did not stabilize the glass against CPS as previously observed in borosilicate glasses that undergo APS, it acted to stabilize the glass matrix and helped maintain overall glass durability. 


\subsection{REFERENCES}

${ }^{1}$ A.D. Cozzi and C.M. Jantzen, "Glass Durability Along the Compositional Continuum Between a Phase Separated Frit and a Homogeneous Glass," to be published in Proceedings of the 1999 American Ceramic Society Annual Meeting.

${ }^{2}$ C.M. Jantzen, J.B. Pickett, K.G. Brown, T.B. Edwards, U.S. Patent \#846,278, "Method of Determining Glass Durability (THERMO)," (1998).

${ }^{3}$ P.R. Hrma, D.K. Peeler, et al., "Property/Composition Relationships for Hanford High-Level Waste Glass Melting at $1150^{\circ}$ C," U.S. DOE Report PNL-10359, Vols. 1 and 2, December (1994).

${ }^{4}$ I. Tovena, T. Advocat, D. Ghaleb, E. Vernaz and F. Larche, "Thermodynamic and Structural Models Compared with the Initial Dissolution Rates of SON Glass Samples," Sci. Basis for Nucl. Waste Mgt., XVII, A. Barkatt and R.A. Van Konynenburg (Eds.), Màt. Res. Soc., Pittsburgh, PA, 595-602 (1994).

${ }^{5}$ C.M. Jantzen, K.G. Brown, and T.B. Edwards, "Predicting Phase Separation in Nuclear Waste Glasses," Ceramic Transactions, American Ceramic Society, Westerville, OH, WSRC-MS-99-00333, Rev. 1 (in press).

${ }^{6}$ W. Vogel, "Chemistry of Glass," American Ceramic Society, Inc., Columbus, OH, pp.111-113, 325 (1985 Translation).

${ }^{7}$ M. Tomazawa, "Phase Separation in Glass," in, Treatise on Materials Science and Technology, Vol. 17, Eds. M. Tomazawa and R.H. Doremus , pp. 71-113, Academic Press, New York (1979).

${ }^{8}$ C.M. Janzten and H. Herman, "Spinodal Decomposition: Phase Diagram Representation and Occurrence," Materials Science and Technology: High Temperature Materials, Vol. 5 (A. Alper, ed), Academic Press, NY, pp. 127-148 (1978).

9 C.M. Jantzen, D. Schwann, J. Schelten and D. Herman, "The $\mathrm{SiO}_{2}-\mathrm{Al}_{2} \mathrm{O}_{3}$ System, I. Later Stage of Spinodal Decomposition and Metastable Immiscibility," Physics and Chemistry of Glasses, 22[5], pp. 122-137 (1981).

${ }^{10}$ C.M. Jantzen, D. Schwann, J. Schelten and D. Herman, "The $\mathrm{SiO}_{z}-\mathrm{Al}_{2} \mathrm{O}_{3}$ System, II. The Glass Structure and Decomposition Model," Physics and Chemistry of Glasses, 22[5], pp. 138-144 (1981).

${ }^{11}$ C.M. Jantzen and H. Herman, "Phase Equilibria in the $\mathrm{SiO}_{z}-\mathrm{Al}_{2} \mathrm{O}_{3}$ System," J. Am. Ceram. Soc., 62[34], pp. 212-214 (1979).

${ }^{12}$ C.M. Jantzen, R.L. Schulz, D.K. Peeler, J.D. Vienna and P.R. Hrma, "Crystallization and Amorphous Phase Separation in HLW Glasses (U)," Report No. WSRC-RP-99-01067 (1999).

${ }^{13}$ D.K. Peeler and P.R. Hrma, "Compositional Range of Durable Borosilicate Simulated Waste Glasses," Emerging Technologies in Hazardous Waste Management, VI (D.W. Tedder and F.G. Pohland, Eds.), Amer. Acad. of Environ. Eng., 323-338 (1996).

${ }^{14}$ C.M. Jantzen, "Phosphate Additions to Borosilicate Waste Glass Cause Phase Separation," DPST-86389 (1986). 
${ }^{15}$ B.A. Staples, D.K. Peeler, G.F. Piepel, J.D. Vienna, B.A. Scholes, and C.A. Musick, "The Preparation and Characterization of INTEC HAW Phase 1 Composition Variation Study Glasses," U.S. DOE Report INEEL/EXT-98-00970 (September, 1998).

${ }^{16}$ C.M. Jantzen, J.B. Pickett, K.G. Brown, T.B. Edwards, D.C. Beam, "Process/Product Models for the Defense Waste Processing Facility (DWPF): Part I, Vol. II, Appendix B," Report No., WSRC-TR-93672, Rev. 1 (1995).

${ }^{17}$ S.L. Marra, R.E. Edwards and C.M. Jantzen, "Thermal History and Crystallization Characteristics of the DWPF Glass Waste Form," High Level Radioactive Waste Management, Proceedings of the $3^{\text {rd }}$ International Conf., Vol. 1, pp. 917-924 (1992).

${ }^{18}$ R.E. Edwards, "SGM-8 - Canister and Glass Temperatures During Filling and Cooling," DPST-87-801 (1987).

${ }^{19}$ Technical Data Summary for the Defense Waste Processing Facility Sludge Plant, DPSTD 80-38-2, Rev. 2, Part 10, Items 330 and 335 (1982).

20 A.D. Cozzi, "Technical Status Report on the Effect of Phosphate and Aluminum on the Development of Amorphous Phase Separation in Sodium Borosilicate Glasses (U)," Report No.,WSRC-TR-98-00327, Rev. 1 (1998).

${ }^{21}$ M. Tomozawa, "A Source of the Immiscibility Controversy of Borate and Borosilicate Glass Systems," J. Amer. Ceram. Soc., 82[11], pp. 206-208 (1999).

22 C.M. Jantzen, N.E. Bibler; D.C. Beam, C.L. Crawford and M.A. Pickett, "Characterization of the Defense Waste Processing Facility (DWPF) Environmental Assessment (EA) Glass Standard Reference Material (U)," Report No. WSRC-TR-92-346, Rev. 1 (1993).

${ }^{23}$ M.H. Langowski, H. Li, P. Hrma, M.J. Schweiger and D.E. Smith, "The Effect of Phosphate on Crystallization, Viscosity, and Chemical Durability of Simulated Hanford Site High-Level Radioactive Waste Glasses,"Ceramic Transactions, V. 72, V. Jain and D.K. Peeler (Eds.), Amer. Ceram. Soc., Westerville, OH, pp. 291-298 (1996).

${ }^{24}$ C.M. Jantzen and D.F. Bickford, "Leaching of Devitrified Glass Containing Simulated SRP Nuclear Waste," Sci. Basis for Nuclear Waste Management, VIII, C.M. Jantzen, J.A. Stone and R.C. Ewing (eds.), Materials Research Society, Pittsburgh, PA, pp. 135-146 (1985). 